REGINA MARIA AZEVEDO

\title{
O DISCURSO TERAPÊUTICO DE MILTON ERICKSON: UMA ANÁLISE À LUZ DOS PADRÕES DA PROGRAMAÇÃO NEUROLINGUÍSTICA
}

São Paulo 


\section{O DISCURSO TERAPÊUTICO DE MILTON ERICKSON: \\ UMA ANÁLISE À LUZ DOS PADRÕES DA PROGRAMAÇÃO NEUROLINGUÍSTICA}

(Versão original)

Tese apresentada ao Instituto de

Psicologia da Universidade de São

Paulo para obtenção do título de Doutor

Programa de Pós-Graduação em Psicologia Social e do Trabalho

Orientador: Prof. Dr. Sigmar Malvezzi

São Paulo

2012 


\section{AUTORIZO A REPRODUÇÃO E DIVULGAÇÃO TOTAL OU PARCIAL DESTE TRABALHO, POR QUALQUER MEIO CONVENCIONAL OU ELETRÔNICO, PARA FINS DE ESTUDO E PESQUISA, DESDE QUE CITADA A FONTE.}

Azevedo, Regina Maria.

O discurso terapêutico de Milton Erickson: uma análise à luz dos padrões da Programação Neurolinguìstica / Regina Maria Azevedo; orientador Sigmar Malvezzi. -- São Paulo, 2012.

$169 \mathrm{f}$.

Tese (Doutorado - Programa de Pós-Graduação em Psicologia. Área de Concentração: Psicologia Social) - Instituto de Psicologia da Universidade de São Paulo.

1. Erickson, Milton H., 1901-1980 2. Hipnose 3. Terapia Estratégica 4. Discurso 5. Programação neurolinguística I. Título. 
Regina Maria Azevedo

O discurso terapêutico de Milton Erickson: uma análise à luz dos padrões da Programação Neurolinguìstica

Tese apresentada ao Instituto de Psicologia da Universidade de São Paulo para obtenção do título de Doutor

Aprovada em:

Banca Examinadora:

Prof. Dr.

Instituição:

Assinatura

Prof. Dr.

Instituição:

Assinatura

Prof. Dr.

Instituição:

Assinatura

Prof. Dr.

Instituição:

Assinatura

Prof. Dr.

Instituição:

Assinatura 
A meus pais, Adão da Silva Azevedo e Elena Costa Azevedo; a meus irmãos, Sonia, Ana e Fernando, pelo amoroso e incondicional apoio ao longo de minha vida.

Ao Prof. Dr. Sigmar Malvezzi pela condução firme e generosa 


\section{AGRADECIMENTOS}

Muitas pessoas foram importantes para a realização deste trabalho; são, pois, merecedoras dos mais sinceros e amorosos agradecimentos:

ao caríssimo Prof. Dr. Sigmar Malvezzi, pelo saber compartilhado, generosidade e incansável colaboração;

à querida Profa. Dra. Maria do Socorro Nóbrega, pelo apoio incondicional, parceria generosa e orientação firme no meu Mestrado;

à querida Profa. Dra. Zélia Ramozzi Chiarottino, do Instituto de Psicologia (IP-USP), especialmente pelo exemplo de vida e pela colaboração, sempre, através dos conhecimentos compartilhados no Núcleo "Filosofia da Ciência e Psicologia", do qual é a responsável, no IP-USP;

ao Prof. Dr. José Roberto Cardoso, diretor da Escola Politécnica da USP, pela generosa confiança em mim depositada;

aos Professores Dr. Adherbal Caminada Netto e Dr. Gil Anderi da Silva, coordenadores das áreas da Qualidade, Gestão Ambiental e Manutenção e Manufatura do PECE - Programa de Educação Continuada em Engenharia - da Escola Politécnica da Universidade de São Paulo (EPUSP); ao confiarem a mim disciplinas voltadas à Comunicação e à Motivação dessa respeitada instituição de ensino, foram os responsáveis por meu retorno a esta Universidade;

ao Prof. Dr. Gilberto Martha de Souza, coordenador da área de Manutenção e Manufatura do PECE, pelo apoio e confiança; ao Prof. Dr. Gilberto Massarani, colega do PECE e pesquisador na área da PNL;

in memoriam, à Profa. Dra. Jeanne Marie Machado de Freitas, que com gentileza e ternura peculiares deu-me as boas-vindas em meu "retorno de filha pródiga" à Escola de Comunicações e Artes (ECA-USP), 22 anos após minha graduação; com seu espírito científico, abriu espaço para que nossa Dissertação de Mestrado encontrasse seu lugar nas Ciências da Linguagem, incentivando sempre a continuação de meus estudos; 
à Profa. Dra. Dulcília Buitoni, grande incentivadora e parceira na revista Caligrama;

aos colegas queridos do Instituto de Psicologia, especialmente aos do Núcleo "Filosofia da Ciência e Psicologia", Alessandro Shimabucuro, Alberto Nery, Ana Virgínia, Christina D'Albertas, Douglas Balila, Paula Boero, Paulo Candido e Úrsula Heymeyer, com quem trocamos idéias, incertezas, bibliografia e carinho nos momentos de dificuldade; ao caro colega João Urso, pela ajuda na elaboração de nosso projeto inicial para a entrevista de admissão no IP-USP;

do quadro de professores do Instituto de Psicologia, cabe ainda destacar as importantíssimas colaborações da Profa. Dra. Marlene Guirado, pelo incentivo, e atenção a este estudo, e das Profas. Dras. Livia Mathias Simão e Eda Tassara, pelos ensinamentos;

às psicólogas Clô Guilhermino, Elaine Martins, por compartilharem comigo suas descobertas sobre a PNL;

aos queridíssimos Marcos Costa Ferreira Santos, Marinalva Almeida Santos Gil, Rosangela Serikaku Sigaki e Selma Aparecida Rezzetti Loyola, da Secretaria PósGraduação do PST-IP-USP, anjos-guardiães, a quem sempre pudemos recorrer nos momentos de aflição estudantil, por todas as facilidades disponibilizadas para que pudéssemos enfrentar sem atropelos os trâmites burocráticos;

aos queridos alunos do PECE, pela produtiva e amorosa troca de experiências e informações; e aos colegas e funcionários do PECE pela amizade, cordialidade, dedicação, bom atendimento e contribuição efetiva para meu desempenho profissional;

à gata Suzana, companheira fiel nas longas noites de estudo.

Os amigos merecem um capítulo à parte, pois possuem cadeira cativa em nosso coração; para poupar espaço, confinamos alguns dos que participaram diretamente deste projeto num único parágrafo. Assim sendo, agradeço à minha querida prima, Profa. Dra. Helena Alves de Carvalho Sampaio, pela exemplar vida acadêmica que sempre me serviu de inspiração e por sua ajuda na elaboração desta tese; à promissora doutoranda Marcela Miura Satow, pelo talento e a especial alegria que exala de sua graciosa juventude; aos meus sobrinhos queridos, Ronaldo, Rodrigo, Flavia, Roberta, Carolina, Letícia, Pedro e Julia; ao Prof. MsC Moacyr Albano Braz, 
pelo ombro acolhedor, pela amizade fiel e torcida incansável que persistem por mais de 40 anos; aos doutorandos Rodrigo Provasi e Olívio Guedes, ouvintes amigos, depositários, em muitos momentos, das minhas aflições acadêmicas; aos queridíssimos amigos de todas as horas Lívia Tonso, Maria Cecília Candeias, Silvia Galant, Yayo Miura, Miriam Sardinha Azevedo, Maria José dos Santos, Rui Satow, Toni Galvéz, Guina Martins, por comemorarem comigo o início, o fim e o meio.

Valeu a torcida! Saúde, sorte e sucesso a todos nós! 


\section{RESUMO}

Este estudo apresenta o trabalho do psicanalista e hipnoterapeuta americano Milton Hyland Erickson a partir de seus dados biográficos e de sua relevância para a chamada terapia estratégica, propondo, em consonância com sua experiência profissional, uma nova epistemologia para a mudança; propõe ainda uma comparação entre a trajetória de Freud e a de Erickson em relação à hipnose, bem como um apanhado histórico sobre essa técnica. Com base nessa recuperação teórica, os padrões ericksonianos de linguagem são investigados à luz do Metamodelo e do Modelo Milton, criações de Richard Bandler e John Grinder, tomando por base alguns conceitos da Programação Neurolinguística (PNL) tais como "sistemas representacionais", "filtros", "modelagem", "espelhamento" e "rapport". Empreende-se uma análise do discurso ericksoniano a partir de três casos selecionados dentre seus atendimentos clínicos, evidenciando os padrões de linguagem apresentados nas categorias e subcategorias do Metamodelo e do Modelo Milton, com o objetivo de validá-los tanto teórica quanto empiricamente.

Palavras-chave: Milton Erickson, hipnose, terapia estratégica, discurso, Programação Neurolinguística (PNL) 


\section{ABSTRACT}

This study aimed at scrutinizing Milton Hyland Erickson's theoretical framework and therapeutic methodology with a view to the understanding of their relevance to the so-called strategic therapy. That aim was carried out through analyses of issues such as Erickson's professional experience, his shared points and differences with Freudian hypnosis and particularly his patterns of discourse as well as his very clinical technique. Those analyses were accomplished under the guidance of the Metamodel and the Milton Model as proposed by Richard Bandler and John Grinder within the references and concepts comprised in the Neuro-Linguistic Programming such as "representational systems", "filters", "modeling", "mirroring" and "rapport". In order to ground and illustrate the theoretical analyses, this work was enriched by the scrutiny of three Ericksonian clinical cases. This strategy proved to be effective since it has provided evidences about both Erickson's language patterns and empirical data for the observation of the categories and subcategories of the Metamodel and Milton's Model, as a kind of a quest for validation of his theory and methods. The results put into light Erickson's understanding of the therapeutic work.

Key words: Milton Erickson, hypnosis, therapeutic strategy, discourse, NeuroLinguistic Programming (NLP) 


\section{RESUMEN}

Este estudio tuvo por objetivo el examen de la teoría y de los métodos terapéuticos de Milton Erickson en búsqueda de la comprensión de la relevancia de su trabajo y de la terapia estratégica. Este reto fue desarrollado a través del análisis de cuestiones tales como de su experiencia profesional, sus puntos comunes y sus diferencias con Sigmund Freud y específicamente su lenguaje. Estos análisis fueron guiados por el Metamodelo y el Modelo Milton como los proponen Richard Bandler y John Grinder dentro del marco referencial de la Programación Neuro Lingüística a través de conceptos tales como "sistemas representacionales", "filtros", "modelaje", "espejamiento" y "rapport". Con el reto de fundamentar y ilustrar los análisis teóricos este trabajo fue enriquecido con el escrutinio de tres casos clínicos publicados por Erickson. Esa estrategia fue efectiva porque ofreció evidencias empíricas de los estándares del lenguaje ericksoniano y facilitó la constatación de las categorías y subcategorías del Metamodelo y de del Modelo Milton, como una especie de validez de su teoría y de sus métodos. Los resultados aclararon la comprensión ericksoniana del trabajo terapéutico.

Palabras clave: Milton Erickson, hipnosis, terapia estratégica, discurso, Programación Neurolingüística (PNL) 


\section{LISTA DE FIGURAS}

Figura 1 - Milton H. Erickson.................................................................... 5

Figura 2 - Milton Erickson idoso.................................................................... 5

Figura 3 - Exemplo de constituinte......................................................66

Figura 4 - Exemplo de transformação.........................................................66 


\section{LISTA DE QUADROS}

Quadro 1 - Unidades do Instituto Milton Erickson no Brasil.........................26

Quadro 2 - Paradigmas terapêuticos da Psicologia tradicional x

Paradigmas terapêuticos da Psicologia ericksoniana.................36

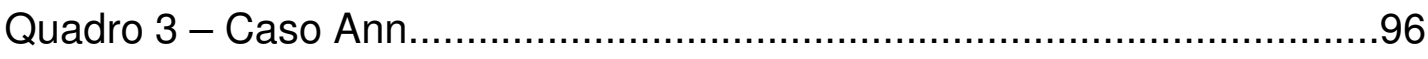

Quadro 4 - Caso Menino de dez anos....................................................109

Quadro 5 - Caso Menino de doze anos.................................................113 


\section{LISTA DE SIGLAS}

Cl Coleta de informações

LME Limites do modelo do emissor

MFS Má-formação semântica

$P \quad$ Pressuposições

PEI Padrões de eliciação indireta

PNL Programação Neurolinguística 


\section{SUMÁRIO}

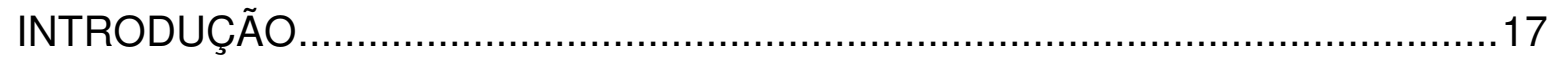

1. MILTON ERICKSON: RELEVÂNCIA NO QUADRO DA PSICOLOGIA .............21

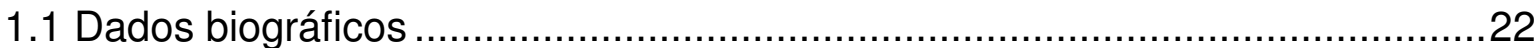

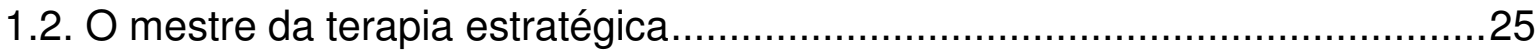

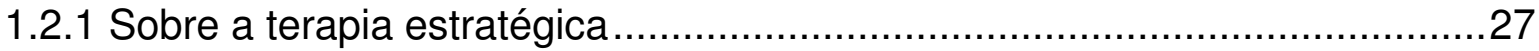

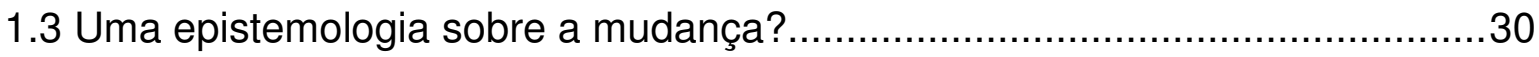

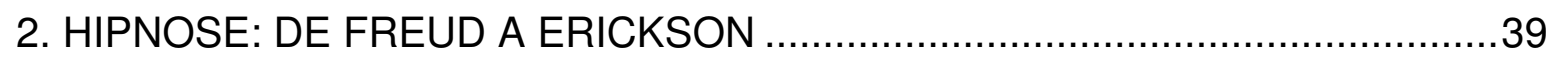

2.2 Apanhado histórico sobre as teorias da hipnose ..........................................39

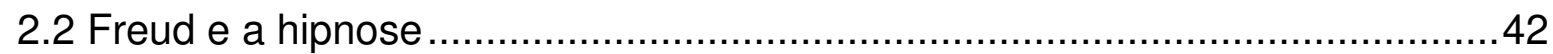

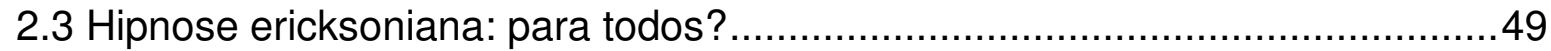

2.3.1 Os dez princípios fundamentais da hipnoterapia ericksoniana ...................54

2.4 Hipnose: novos usos consagrados a partir de Erickson ...............................57

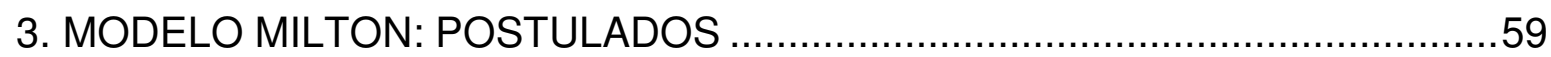

3.1 Modelo Milton: a origem...................................................................... 59

3.2 Conceitos relevantes da PNL para a compreensão do Modelo Milton .............61

3.2.1 Modelo de mundo, sistemas representacionais e filtros .............................61

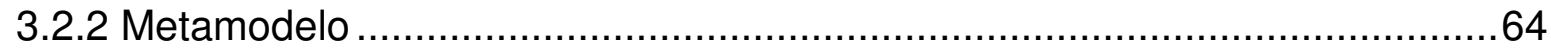

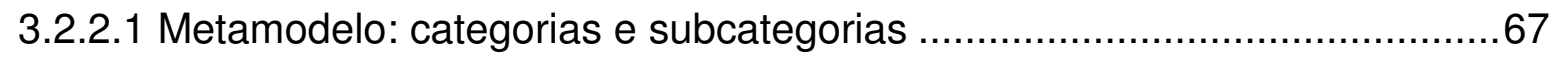

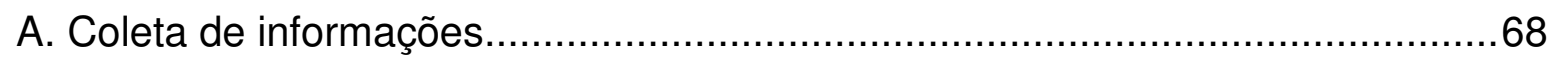

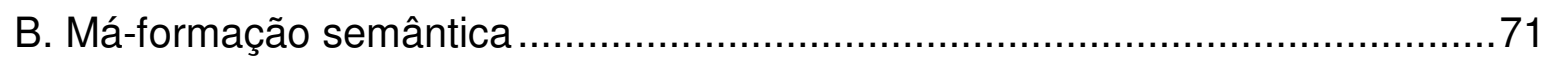

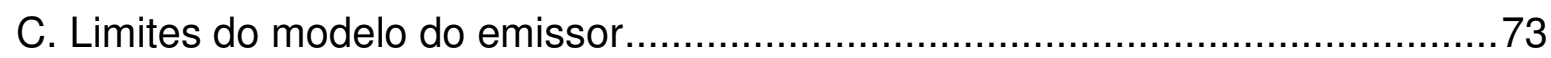

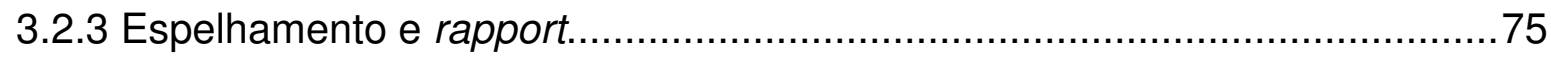

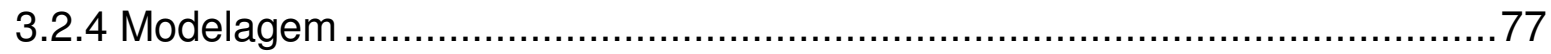

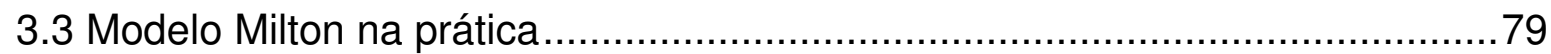

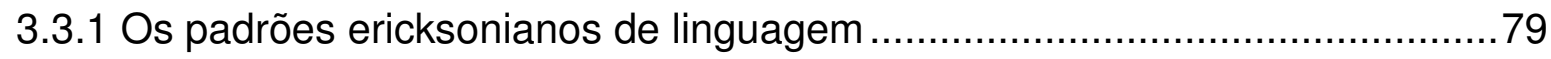

3.3.2 Modelo Milton: inversão das categorias do Metamodelo ..............................80

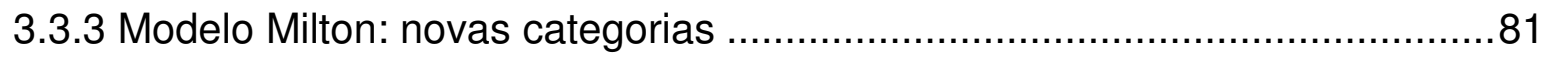

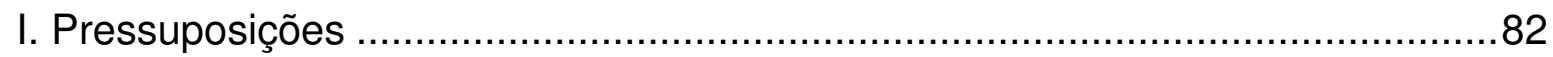

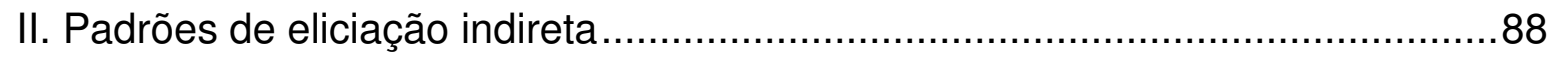

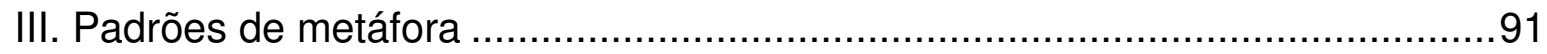




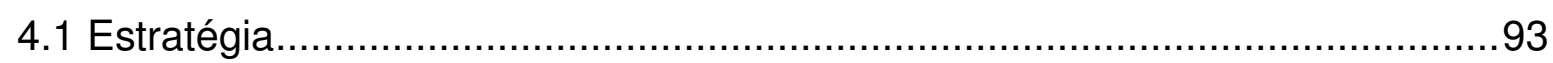

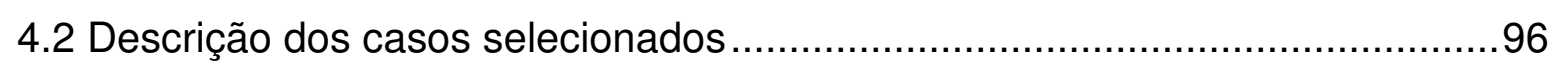

4.3 Análise dos casos selecionados: leitura vertical ..........................................98

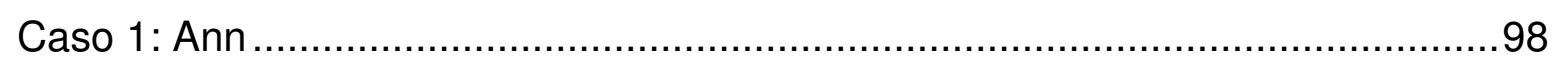

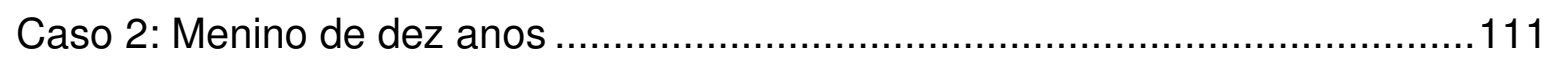

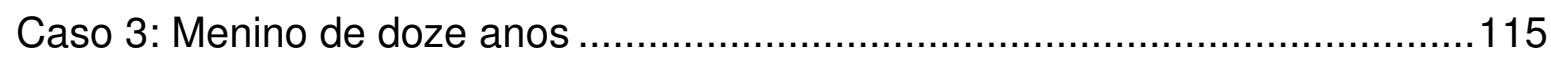

4.4 Análise dos casos selecionados: leitura horizontal....................................123

4.4.1 Ocorrências referentes à primeira categoria do Metamodelo ......................123

4.4.2 Ocorrências referentes à segunda categoria do Metamodelo ......................127

4.4.3 Ocorrências referentes à terceira categoria do Metamodelo ......................130

4.4.4 Ocorrências referentes à primeira categoria do Modelo Milton....................133

4.4.5 Ocorrências referentes à segunda categoria do Modelo Milton................... 146

4.4.6 Ocorrências referentes à terceira categoria do Modelo Milton.....................146

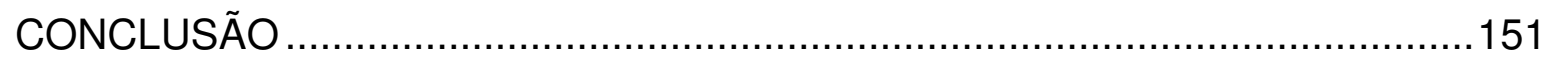

REFERÊNCIAS BIBLIOGRÁFICAS ........................................................155

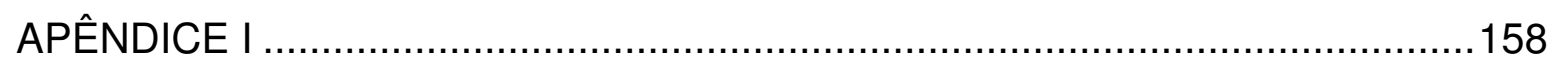




\title{
INTRODUÇÃO
}

\begin{abstract}
Uma das maneiras de encarar a terapia estratégica de Milton Erickson é como uma extensão lógica da técnica hipnótica. Do treinamento em hipnotismo resulta a habilidade para observar as pessoas e levá-las a seguir as instruções, e para usar as próprias palavras, entonações e movimentos corporais para influenciar as pessoas. É também da hipnose que vem a concepção da pessoa como mutável, uma apreciação da maleabilidade do espaço e do tempo e ideias específicas sobre como levar outra pessoa a se tornar mais autônoma.
\end{abstract}

JAY HALEY

Este estudo propõe investigar a grande narrativa do psicoterapeuta americano Milton Erickson e sua contribuição no cenário atual da Psicologia, através dos padrões de linguagem observados em seus atendimentos terapêuticos.

Considerado mundialmente um terapeuta singular, sua trajetória profissional deu origem a The Milton $\mathrm{H}$. Erickson Foundation, instituição voltada ao treinamento de profissionais da saúde para o uso das técnicas hipnóticas ericksonianas e de outros estratagemas linguísticos e não-verbais presentes em seu discurso terapêutico, hoje com 127 unidades espalhadas por 32 países, incluindo o Brasil.

Erickson inspirou Richard Bandler e John Grinder na criação da Programação Neurolinguística (PNL), uma técnica sobre terapia e linguagem, que surgiu nos Estados Unidos, em meados da década de 70. Além dos padrões discursivos singulares, que culminaram na criação do Modelo Milton por Bandler e Grinder, Erickson também se destacou como uma fonte importante para o estudo de técnicas focadas no espelhamento e rapport e, é claro, no que se refere à hipnose e à hipnoterapia.

No Brasil, sua ideias e técnicas não são tão populares como nos Estados Unidos. A pergunta inspiradora deste trabalho foi fundamentada, inicialmente, nesta diferença de receptividade. Dono de um currículo valoroso - Erickson era médico psiquiatra, Mestre em Psicologia, hipnoterapeuta consagrado e professor - e bastante 
respeitado em seu país de origem, pouco se ouvira falar dele por aqui; a bibliografia dedicada ao trabalho de Milton Erickson, no Brasil, é ainda escassa. Numa consulta à rede mundial de computadores, o site de uma das maiores livrarias brasileiras, trazia apenas dois títulos publicados em português - um deles, lançado em 2009, sobre seu método de hipnoterapia, e outro, de sua autoria, atualmente esgotado. Já o site de uma grande livraria americana disponibilizava mais de 130 títulos publicados pelo próprio autor e também sobre sua obra.

Como pesquisador, Erickson publicou mais de 1700 páginas de artigos acadêmicos, principalmente sobre o uso da hipnose, da indução indireta e de metáforas aplicadas em seus atendimentos clínicos. Durante toda sua vida, despertou a admiração de profissionais sempre empenhados em acompanhar e registrar seus estudos, influenciando diretamente Ernest Rossi, Jeffrey Zeig, John Weakland e Jay Haley, conhecido como o criador da terapia estratégica, além de, direta e indiretamente, contribuir com o amigo Gregory Bateson no projeto de Palo Alto, liderado por Bateson.

No Brasil, como dito, raros são os estudos acadêmicos em que Erickson é citado, quase sempre, focados em suas técnicas hipnóticas, para fins médicos e/ou odontológicos. No entanto, tem sido crescente a divulgação de seus trabalhos através de seminários e cursos promovidos pelos Institutos Milton Erickson aqui instalados, com fins psicoterapêuticos, principalmente na última década - nove das 14 unidades aqui sediadas surgiram a partir dos anos 2000.

Essas diferenças do impacto do pensamento ericksoniano se colocam lado a lado com outras tão ou mais instigantes, uma vez que, para muitos, Erickson apresenta um novo olhar epistemológico sobre o tema da hipnose e da própria Psicologia.

No tocante a hipnose, a substituição do transe pelo uso de metáforas e da indução indireta com efeito hipnótico são os temas mais evidenciados entre seus seguidores. Da hipnose tradicional, em que o sujeito, dependendo da intensidade do transe, era colocado em estado de torpor, pouco restou na prática da chamada hipnoterapia ericksoniana. O estado hipnótico é alcançado facilmente por meio da habilidade do terapeuta, que utiliza certos padrões linguísticos para confundir o cliente, dele extraindo alguns conteúdos internos para criar, a partir desses conteúdos, uma estratégia de mudança do estado atual do paciente, visando à melhora num futuro breve, começando pelo agora. 
Esse traço da terapia ericksoniana, que não se relaciona diretamente com 0 passado do cliente, constitui um dos novos paradigmas apontados pelos estudiosos de sua teoria frente aos apresentados até então pela Psicologia atual, em especial pela Psicanálise, em que conteúdos pregressos da vida do paciente são sobremaneira valorizados. Há também a questão da subjetividade: o sujeito da terapia estratégica ericksoniana é considerado individualmente, a partir de sua história única, pessoal e intransferível, diferentemente do sujeito objetivizado pela Ciência de modelo positivista em que se pretende inserir a Psicologia. Além disso, outra relevante questão se coloca: por que Erickson persistiu em seus estudos e aplicações da hipnose quando esta foi abandonada por Freud?

Observou-se também as dificuldades criadas pelo fazer pragmático de Erickson: como ele próprio, diferentemente de Freud e outros, não organizou sua própria teoria, esta foi construída a partir da interpretação e dos registros de vários de seus seguidores. Haveria assim, uma psicoterapia ericksoniana segundo a visão de Haley, outra, segundo Zeig, um modelo concebido por Bandler e Grinder? Como estudá-la, e a partir de quais elementos? É certo que, apoiados nas próprias publicações de Erickson em que muitos de seus padrões são discutidos - metáforas, indução indireta, a ausência do transe, substituído pelo estado hipnótico - é possível encontrar regularidades até mesmo entre os autores diversos. Como compatibilizálas, de forma a apresentar uma metodologia capaz de analisar seus casos de forma a constatar a presença desses padrões e seus efeitos?

Não bastassem as dificuldades apontadas, pairava ainda sobre Erickson certa mística que consignava a eficiência de seus resultados à sua própria figura - devido à poliomielite que enfrentara na adolescência, sua mobilidade era restrita, passando boa parte de sua vida na dependência de dispositivos para a própria locomoção, o que fazia dele uma pessoa incomum - um "curandeiro ferido", como será visto ao longo deste estudo. Havia ainda quem o revestisse de uma aura "sobrenatural", um certo grau de "endeusamento", atribuindo a ele as qualidades de um xamã, agindo ora como um pai autoritário, ora como uma criança despreocupada com o julgamento da sociedade.

Motivado por essas questões, este estudo foi estruturado conforme o plano descrito a seguir: 
- o primeiro capítulo apresenta dados biográficos de Milton Erickson, sua relação com a terapia estratégica e uma discussão sobre os novos paradigmas terapêuticos ericksonianos frente aos paradigmas terapêuticos da Psicologia tradicional;

- o segundo capítulo faz um apanhado histórico sobre as mais importantes teorias da hipnose através de seus principais divulgadores ao longo do tempo; mostra, a seguir, o envolvimento de Freud com a hipnose, culminando com o surgimento da Psicanálise; apresenta as ideias de Erickson em relação à hipnose até chegar à hipnoterapia ericksoniana e as principais diferenças das visões freudiana e ericksoniana quanto à hipnose;

- o terceiro capítulo apresenta o Modelo Milton e o Metamodelo da Programação Neurolinguística (PNL) com suas categorias e subcategorias, instrumentos essenciais para a análise dos casos selecionados, bem como outros conceitos relevantes para a compreensão de ambos, todos integrantes do corolário da PNL, a saber: modelo de mundo, sistemas representacionais, filtros, espelhamento, rapport e modelagem;

- o quarto capítulo apresenta as análises dos casos selecionados através de um método criado para este fim específico que inclui uma "leitura vertical" e uma "leitura horizontal" a fim de mostrar as ocorrências dos padrões ericksonianos de linguagem e discutir seus efeitos terapêuticos

- por fim, a conclusão apresenta os principais achados ao longo de toda essa narrativa, visando responder aos questionamentos apresentados nesta Introdução;

- o Anexo I, no final do trabalho, traz a reprodução integral dos casos analisados.

Espera-se, por meio da estrutura apresentada, integrar Milton Erickson na grande narrativa da Psicologia atual, com todas as singularidades e regularidades de seu pensamento original, visando enriquecer o fazer terapêutico com os instrumentos oferecidos pela terapia estratégica, tal como praticada por Erickson e seus seguidores. 


\title{
1. MILTON ERICKSON: RELEVÂNCIA NO QUADRO DA PSICOLOGIA
}

\begin{abstract}
É um erro acreditar que a ciência consiste apenas em proposições definitivamente provadas, e é injusto exigir que assim seja. Tal exigência é feita somente por aqueles que anelam mais que tudo pela Autoridade, e precisam substituir seu catecismo religioso por outro, ainda que de caráter científico.
\end{abstract}

SIGMUND FREUD

Como explicitado na Introdução, este estudo objetiva examinar obra de Milton Erickson a partir do exame das técnicas discursivas empregadas em sua clínica terapêutica, verificando o impacto das intervenções ericksonianas frente aos cânones da Psicologia.

Para muitos profissionais, como será visto adiante, a contribuição mais significativa de Erickson refere-se a seus progressos quanto ao uso da hipnose; outros destacam seu sucesso no uso estratégico da linguagem, em especial por meio da sugestão indireta, emprego de metáforas, anedotas, vinculações. Conhecido como o médico hipnotista mais proeminente do mundo, é também consagrado por sua habilidade no uso da terapia estratégica.

Erickson merece um olhar cuidadoso, em vista de ser tão valorizado por alguns estudiosos e totalmente desconhecido por outros. Zeig (1983, p. 21) estabelece uma comparação entre Freud e Erickson, dizendo que não seria "uma hipérbole afirmar que a história demonstrará que o que Freud contribuiu para a teoria da psicanálise, Erickson contribuiu para a prática da psicoterapia, como será reconhecido no futuro". Neubern (2002) e Lankton (1991) apontam Erickson como o responsável por novos paradigmas epistemológicos no campo da Psicologia, defendendo que seus atendimentos contrariam algumas das práticas tradicionais de análise clínica, como apresentado seção 1.3 .

Este capítulo visa apresentar Milton Erickson a partir de seus dados biográficos e de sua trajetória profissional, bem como evidenciar o impacto da abordagem clínica ericksoniana na construção de um novo paradigma epistemológico no campo da Psicologia. 


\subsection{Dados biográficos}

Milton Hyland Erickson nasceu em Aurum, Nevada, em 15 de dezembro de 1901. Durante toda a vida, apresentou vários problemas de saúde, dentre os mais dramáticos, um ataque de poliomielite aos 17 anos, que acarretou graves sequelas. Segundo seu próprio relato:

Um ataque de poliomielite anterior a 1919, logo após ter-me
graduado no curso secundário, tornou-me quase totalmente paralítico
por vários meses, mas com minha visão, audição e pensamentos
intactos. Enquanto estive em quarentena na casa da fazenda, havia
pouca diversão disponível. Afortunadamente, eu sempre me
interessara por comportamento humano e havia muita gente para
observar por lá. Minha incapacidade de me mover restringiu a
intercomunicação, tanto de minha parte quanto das outras pessoas
em relação a mim. Embora eu já soubesse alguma coisa sobre
linguagem corporal e outras formas de comunicação não-verbal,
ficava assombrado ao descobrir as frequentes - e, para mim, muitas
vezes surpreendentes - contradições entre a comunicação verbal e
não-verbal num simples colóquio. Isso estimulou muito meu interesse
e eu intensifiquei minhas observações em cada oportunidade
(ERICKSON in BANDLER; GRINDER, 1975, p. vii, PREFÁCIO). ${ }^{1}$

Este relato destaca o papel das dificuldades pessoais de Erickson no desenvolvimento de suas habilidades relacionadas às técnicas de espelhamento e rapport, como apresentadas no capítulo 3 desta tese.

Como assinala Haley (1991), "a despeito de seus dois ataques de pólio e da necessidade de andar desajeitadamente com muletas, ele era vigoroso e gozava de boa saúde". Erickson soube também explorar recursos de criatividade e imaginação a partir de sua condição motora limitante, como descreve o psiquiatra americano WOLBERG:

Como resultado da sua própria experiência pessoal, Erickson era um expert no uso de estratagemas para vencer resistências e tinha sua mente aguçada por uma desafiante teimosia para a transposição dos obstáculos físicos virtualmente insuperáveis (WOLBERG in ZEIG, s/d, prefácio, p.19).

Erickson cursou a Universidade de Wisconsin e concluiu sua formação médica no Colorado General Hospital; simultaneamente, diplomou-se como Mestre em Psicologia. Após especialização no Colorado Psycopathic Hospital, atuou como

\footnotetext{
${ }^{1}$ inédito em língua portuguesa, tradução da Autora.
} 
psiquiatra no Rhode Island State Hospital. Em 1930, tornou-se psiquiatra-chefe do Serviço de Pesquisa do Worcester State Hospital, em Massachussetts; em 1934 transferiu-se para Eloise, Michigan, como diretor de pesquisa e treinamento psiquiátrico do Wayne County General Hospital and Infirmary.

Na mesma época, atuava como professor associado de psiquiatria no Wayne State University College of Medicine e como professor de pós-graduação. Durante breve período, foi também professor de psicologia clínica na Michigan State University, em East Lansing.

Em 1948, estabeleceu-se em Fênix, Arizona, devido, principalmente, à saúde precária, iniciando clínica particular. Foi membro da American Psychiatric Association, da American Psychological Association e da American Psychopathological Association, além de participar de diversas sociedades de hipnose médica na Europa, América Latina e Ásia como membro honorário. Presidente fundador da American Society for Clinical Hypnosis, era também o editorresponsável pela revista publicada por essa entidade.

Após 1950, dividia seu tempo entre os atendimentos na movimentada clínica particular, em Fênix, e as frequentes viagens para ministrar seminários e palestras por todo território americano e por diversos países estrangeiros. Apesar de tantas atividades e dos problemas de saúde, publicou mais de 1700 páginas de artigos acadêmicos, além de diversos livros. Grande parte de sua obra foi resgatada por colaboradores como Ernest Rossi, Jay Haley e Jeffrei Zeig, dentre outros, que se ocuparam, inclusive, da transcrição de alguns de seus seminários e atendimentos terapêuticos.

Mantendo tanto quanto possível a postura, Erickson destacava sua singularidade e expertise fazendo uso adequado da técnica de espelhamento, descrita adiante, no capítulo 3, investindo-se, conforme a ocasião, de vários papéis relacionados à autoridade, conforme denota seu discurso:

Atuando de maneira diferenciada com cada paciente, como conselheiro, analista, conciliador, árbitro, advogado, mediador, mentor, aceitando autoridade ou agindo como um pai punitivo, Erickson realçava as características únicas de cada indivíduo que, motivado por necessidades singulares e defesas negativas, requeria modelos originais de abordagem ao invés de técnicas ortodoxas, dogmáticas e sem imaginação. Ele considerava a si mesmo e suas palavras, entonação, jeito de falar e movimentos corporais como 
veículos de influência que poderiam promover mudanças. Muito mais interessado em ação do que em teoria, Erickson considerava a teoria tradicional uma espécie de obstáculo que ancorava os terapeutas numa pedreira de imponderáveis desesperanças (ZEIG, s/d, p. 17).

Erickson também era daltônico de nascença, mas não se deixou limitar por isso; apreciava a cor roxa, que era capaz de distinguir, incorporando-a a sua indumentária e aos objetos seu consultório, sendo frequentemente presenteado por seus alunos com adornos dessa cor.

Ao buscar sua ajuda na forma de terapia, seus discípulos e pacientes encontravam um homem aparentemente identificado com a sisudez, encaixado numa cadeira de rodas, inserido num curioso ambiente decorado em tons de púrpura. Tais singularidades marcavam a presença de um ser humano original e excêntrico, capaz de despertar a um tempo, curiosidade e admiração.

Em 1953, foi novamente hospitalizado; examinado por uma junta médica, os especialistas concluíram que Erickson desenvolvera várias deficiências musculares relacionadas à síndrome pós-poliomielite. Em 1969, com acentuada dificuldade para locomover-se, passou a permanecer em cadeira de rodas por tempo integral.

A partir de 1970, foi perdendo gradualmente a força muscular da língua e das faces; impedido de usar sua prótese dentária, como consequência, teve a pronúncia prejudicada. Em 1974, abandonou definitivamente suas atividades de psicoterapeuta clínico, vindo a falecer em 27 de março de 1980 em Fênix, Arizona, vítima de infecção aguda.

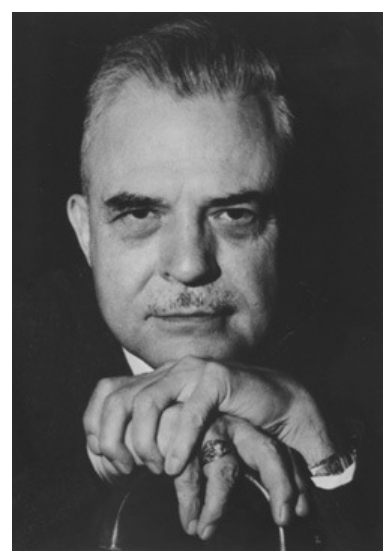

Figura 1 - Milton H. Erickson

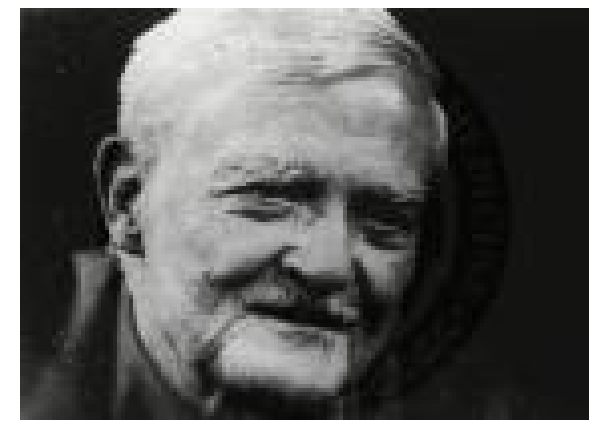

Figura 2 - Milton Erickson idoso 


\subsection{0 mestre da terapia estratégica}

Erickson é referência para psicoterapeutas de diversos países. Segundo MASSON (1994), Erickson influenciou uma série de notáveis e ecléticos psicoterapeutas como Margaret Mead, Gregory Bateson, Paul Watzlavick, Don Jackson, Jay Haley, John Weakland, Richard Bandler e John Grinder.

Jeffrey Zeig ${ }^{2}$, um de seus principais estudiosos e colaboradores, a ele assim se referiu:

"Gênio" é um espírito que acompanha uma pessoa. Significa também uma pessoa dotada de uma habilidade e uma inventividade mental quase transcendentais. A genialidade de Erickson era derivada da conjunção de sua inteligência, humanidade, inventividade, curiosidade e uma extraordinária percepção. Também trabalhava diligentemente para desenvolver e aprimorar suas habilidades.

A genialidade de Erickson revelava-se em quatro áreas: como hipnólogo, como psicoterapeuta, como professor e como pessoa que transformou suas deficiências físicas em vantagem. Consideradas em conjunto, suas realizações nestes quatro campos fazem-no parecer uma pessoa superior (ZEIG, s/d, p. 33-34).

Em outra obra, Zeig (1983) consagra Erickson como "a maior autoridade em hipnoterapia e em psicoterapia breve estratégica", "o maior comunicador do mundo", "o principal psicoterapeuta do século [XX]". Mesmo abstraindo-se o tom eufórico de seus admiradores, consta dos relatos sobre a vida e obra de Erickson que era dotado de personalidade e método incomuns, exercendo grande fascínio sobre aqueles que dele se aproximavam. Como observa o psiquiatra americano Lewis R. Wolberg ${ }^{3}$ :

Entre os psicoterapeutas há alguns que reverenciam Erickson com tal fervor que chegam aos limites da idolatria. Cada palavra, sentimento, ato ou opinião são vistos como tendo um significado inspirado. Tal "endeusamento", enraizado em expectativas de poder e uma onipotência ilimitada, sem dúvida nenhuma pode levar a decepções. Igualmente prejudiciais são as afirmações de que Erickson não passa de um arauto de métodos efêmeros e fantasias sem fundamento que logo cairão em desuso. Estas atitudes fazem injustiça a uma mente extremamente original, criativa e imaginativa que desenvolveu novas abordagens para solucionar alguns dos muitos e desconcertantes problemas da psicoterapia. Erickson era uma fantástica máquina influenciadora, construída por anos de luta para dominar sua dolorosa deficiência física. Sua coragem,

\footnotetext{
${ }^{2} \mathrm{O}$ psicoterapeuta Jeffrey Zeig, um dos principais divulgadores da obra de Erickson, é também presidente de The Milton H. Erickson Foundation.

3 Fundador do Centro de Pós-graduação em Saúde Mental na New York University.
} 
sensibilidade, percepção e métodos singulares de adaptação fizeram dele, como disse Haley (1973), um terapeuta "não-convencional". Mas, suas abordagens, somadas à sua personalidade "incomum" e ao seu estilo de trabalho, podem não ser tão facilmente transpostas, digeridas e utilizadas por outros (WOLBERG in ZEIG, s/d, prefácio, p. 19).

No Brasil, Erickson também amealha um seleto séquito de admiradores. Sua obra tornou-se conhecida aqui através do terapeuta familiar José Carlos Vitor Gomes que publicou, em 1987, o livro Manual de Psicoterapia Familiar, em que a teoria ericksoniana é mencionada pela primeira vez. Seguiu-se a publicação do livro Terapia não-convencional: as técnicas psiquiátricas de Milton $\mathrm{H}$. Erickson, de autoria de Jay Haley ${ }^{4}$, em 1991. Principal compilador de seus escritos, no prefácio da obra citada, Haley engrossa o coro dos admiradores de Erickson, enfatizando sua importância no cenário mundial:

Erickson pode ser considerado o mestre da abordagem estratégica à terapia. Há tempos é conhecido como o médico hipnotista mais proeminente do mundo; passou sua vida fazendo trabalho experimental e usou a terapia de maneiras infinitamente variadas. (...) Mesmo quando formalmente não utiliza a hipnose, seu estilo de terapia se baseia tanto na orientação hipnótica que o que quer que faça parece ter origem nessa arte. Levou para a terapia uma gama extraordinária de técnicas hipnóticas e, para a hipnose, uma expansão de idéias que a ampliaram para muito além de um ritual de um estilo especial de comunicação (HALEY, 1991, p. 20-21).

Em 1992, o pensamento ericksoniano alcançou, no Brasil, por meio de um seminário organizado por Gomes, em São Paulo, a divulgação almejada por psicoterapeutas e psiquiatras que admiravam seu trabalho. O seminário contou com a presença de 230 profissionais da área de Psicologia, bem como Jeffrey Zeig, fundador da The Milton Erickson Foundation Inc. nos Estados Unidos. Em 1995, Gomes e Zeig empreenderam parceria criando, em São Paulo, o primeiro Instituto Milton Erickson do país. Atualmente, The Milton H. Erickson Foundation ${ }^{5}$ abriga 127 unidades espalhadas por 32 países do mundo, 15 delas no Brasil, conforme quadro a seguir:

\footnotetext{
${ }^{4}$ Terapeuta e professor, Jay Haley é considerado, juntamente com Gregory Bateson, um dos criadores da terapia estratégica breve. É também o responsável pela edição de Advanced techniques of hypnosis and therapy: selected papers of Milton H. Erickson, M.D.

${ }^{5}$ Fonte: http://erickson-foundation.org/ .Acesso em 10 Mar. 2012.
} 


\begin{tabular}{|l|c|}
\hline Cidade /Estado & Ano de fundação \\
\hline Belo Horizonte, MG & 1995 \\
\hline Brasília, DF & 2005 \\
\hline Campinas, SP & 2005 \\
\hline Florianópolis, SC & 1999 \\
\hline Ipatinga, MG & 2003 \\
\hline Juiz de Fora, MG & 2002 \\
\hline Maceió, AL & 2002 \\
\hline Petrópolis, RJ & 2006 \\
\hline Porto Alegre, RS & 1997 \\
\hline Recife, PE & 2003 \\
\hline Ribeirão Preto, SP & 2005 \\
\hline Rio de Janeiro, RJ & 2000 \\
\hline São Paulo, SP & 1995 \\
\hline Vitória, ES & 1997 \\
\hline
\end{tabular}

\section{Quadro 1 - Unidades do Instituto Milton Erickson no Brasil ${ }^{6}$}

Dentre outras atividades, os Institutos organizam cursos para habilitar profissionais quanto ao uso das técnicas hipnóticas e terapêuticas de Milton Erickson e promover o intercâmbio de pesquisadores de todo mundo em torno da obra e do método ericksoniano.

\subsubsection{Sobre a terapia estratégica}

Segundo LEÓN (2002), Erickson começou suas pesquisas em torno da mente humana a partir da hipnose, com Clark Hull (1923-1924), que, mais tarde, desenvolveu uma escola dentro do behaviorismo; apesar disso, Erickson não abraçou o comportamentalismo, avançando na direção da chamada hipnoterapia.

Na década de 30, Margaret Mead e Gregory Bateson viajaram a Bali para estudar seu povo e sua cultura. Em 1939, por sugestão de Abrahan Maslow, Mead escreve a Erickson pedindo ajuda para analisar umas filmagens nas quais os participantes de um ritual entravam em transe religioso mediante uma dança. Mead queria saber se

\footnotetext{
${ }^{6}$ Fonte: http://erickson-foundation.org/institutes/find-an-institute/ Acesso em 10 Mar. 2012.
} 
os dançarinos realmente se encontravam em transe profundo ou se era apenas de uma simulação. Erickson respondeu sua solicitação não apenas descrevendo os critérios desenvolvidos por ele para determinar se os sujeitos estavam experimentando o transe, como também seus próprios critérios para tirá-los do transe. Após uma intensa troca de correspondências, Mead, Bateson e Erickson se encontram em Michigan, no mesmo ano. Nasce daí uma amizade que atravessou décadas.

Quem apresentou Jay Haley a Erickson foi Bateson, durante um seminário por ele organizado em Palo Alto. Anos mais tarde, em 1956, Haley na companhia de John Weakland e do próprio Erickson desenvolveram um trabalho, a partir da ótica ericksoniana, que influenciou o grupo de estudos de Palo Alto. Por este motivo, Erickson é considerado, por muitos autores, co-criador da terapia estratégica, embora a autoria do termo seja atribuída a Haley.

A abordagem estratégica de Erickson difere das correntes tradicionais da primeira metade do século $\mathrm{XX}$, como a psicanálise ou as terapias rogeriana e psicodinâmica, na medida em que estas se apoiam na "ideia de que a pessoa que não sabe o que fazer e procura ajuda deveria determinar o que ocorre na sessão terapêtica" (HALEY, 1991, p. 19).

Estabelecer objetivos, enfocar um problema, intervir deliberadamente na vida de uma pessoa eram considerados comportamentos manipulativos, impróprios para o terapeuta, até então treinado para esperar que o paciente dissesse ou fizesse alguma coisa, evitando planejar ou iniciar qualquer ação durante a sessão. "A terapia estratégica não é uma abordagem particular ou uma teoria, mas um nome para os tipos de terapia nos quais o terapeuta assume a responsabilidade de influenciar diretamente as pessoas", afirma Haley (1991, p. 19-20).

Lankton complementa:

A abordagem ericksoniana é um método de trabalho em que os clientes enfatizam habilidades e talentos comuns, às vezes inconscientes. As metas da terapia são construídas a partir da inteligência e da saúde do indivíduo. Trabalha para destacar as mudanças, e ao reduzir a resistência [do cliente], reduz a dependência em relação à terapia, superando a necessidade de insights, permitindo que o cliente receba totalmente os créditos pelas mudanças (LANKTON, 1990, p. 364, comentário da Autora) 
O autor destaca que a abordagem ericksoniana enfatiza a reorganização criativa dos relacionamentos em vez de focar no diagnóstico da patologia, além de estimular os clientes $^{7}$ a ações que possam ser praticadas fora do consultório.

O conceito de terapia estratégica ganhou impulso a partir da década de 50 , com o desenvolvimento da terapia familiar e das terapias condicionantes baseadas na premissa de que cabe ao terapeuta planejar o que fazer.

Neste novo paradigma de intervenção terapêutica, a hipnose tornou-se relevante, a princípio, pois na passagem da terapia de passiva para ativa, a continuidade com o passado do paciente era mantida por meio de procedimentos hipnóticos.

Como afirma Haley (1991, p. 20), "faz parte da natureza da hipnose o hipnotista iniciar o que vai ocorrer". E aponta a hipnose como origem para diversas terapias:

As terapias condicionantes, com seus diferentes nomes, vêm de Thorndike, através de Skinner, mas suas premissas básicas derivam de Pavlov, que estava imerso em teorias hipnóticas. A terapia comportamental na forma de inibição recíproca foi criada por Joseph Wolpe e nasceu em parte de sua experiência como hipnotista. A psicoterapia dinâmica, particularmente em sua forma psicanalítica, surgiu no grande período de experimentação hipnótica do final do século passado. O método de Freud estava enraizado na hipnose e, embora ele tenha mudado da indução direta do transe para uma abordagem mais indireta, seu trabalho provém da orientação hipnótica (HALEY, 1991, p. 20).

Haley ainda observa que várias habilidades são desenvolvidas a partir do treinamento em hipnose: a de observar as pessoas e os modos complexos como se comunicam; a de motivá-las e levá-las a seguir instruções; a de ensiná-las a influenciar outrem a partir do uso adequado de suas próprias palavras, entonações e linguagem corporal. A relação espaço-temporal também pode ser trabalhada durante o transe hipnótico. O aprimoramento de tais habilidades oferece ao hipnotista a possibilidade de eliciar mudanças no quadro fóbico do paciente:

Assim como um hipnotista pode pensar em transformar um sintoma grave num mais brando, ou de curta duração, ele pode pensar em transformar um problema interpessoal em uma vantagem. É mais fácil para uma pessoa hipnoticamente treinada, do que para a maioria dos terapeutas, apreender a ideia de que os sentimentos subjetivos e as percepções se transformam quando há uma mudança na relação. O modo de pensar estratégico é crucial para a

\footnotetext{
${ }^{7}$ Optou-se, neste estudo pela adoção do termo "cliente" em vez de "paciente", por ser o primeiro mais comum na prática da terapia estratégica e da Programação Neurolinguìstica.
} 
abordagem hipnótica quando usado adequadamente. (HALEY, 1991, p. 21).

Por possuir tais habilidades e usá-las com maestria, Erickson é considerado um terapeuta experimental original ao transferir ideias da hipnose para procedimentos terapêuticos nos quais não seria esperado encontrá-las. Com o passar dos anos, Erickson foi substituindo o transe hipnótico tradicional por outros recursos como a indução indireta, o uso de metáforas, o emprego "artístico" de certos padrões de linguagem, além de aprimorar as técnicas de espelhamento e rapport com o cliente como será explicado no capítulo 3.

\subsection{Uma epistemologia sobre a mudança?}

Os padrões de linguagem hipnótica de Erickson foram reunidos por Richard Bandler e John Grinder, a partir de 1975 (BANDLER; GRINDER, 1975) e sintetizados no chamado Modelo Milton. A partir dessa década, o trabalho do terapeuta americano ganhava notoriedade por meio de seguidores como Haley e Zeig, que também apontavam, em seus estudos, traços do discurso ericksoniano, bem como relatos detalhados de seus atendimentos.

Embora respeitado e admirado em vista dos resultados obtidos junto a seus clientes, pairava na época, nos meios acadêmicos, um consenso quanto à impossibilidade de que as especificidades que caracterizavam os atendimentos de Erickson pudessem constituir um método, de forma a inscrever sua efetiva contribuição nos anais da Psicologia.

Hoffman $(1992)^{8}$, em 1981, comparava o trabalho de Erickson à arte do xamã, do sumo sacerdote, do médico bruxo, que somente poderia ser passada por um mestre extraordinário a um indivíduo extraordinário. Destacava também que, embora Erickson apresentasse resultados excelentes junto a seus clientes, na direção de efetivas mudanças, nenhum dos estudos de seus seguidores apresentava claramente "o quê" deveria ser modificado, tratando-se apenas de um refinamento da arte da persuasão. E complementava:

\footnotetext{
${ }^{8}$ Data da edição original: 1981.
} 
A unidade de tratamento está estreitamente definida como "terapeuta mais problema". Assim, as escolas de terapia associadas ao que com o tempo surgiu como enfoque estratégico tratam de teorias de persuasão ou mudança de comportamento, mas não se importam muito estudando a forma ou regra daquele que tem que mudar. Com um terapeuta ericksoniano não existe o chamado problema, apenas algo definido por alguém como problema. Mude-se a definição, a percepção que "cria" o problema a outra pessoa distinta e o problema já não existirá. Assim, estamos de volta a um deslumbrante jogo de prestidigitação, magia elegante e triunfo do mistério (HOFFMAN, 1992, p. 222).

Décadas mais tarde, Neubern (2002) defende que a abordagem estratégica de Erickson aponta para profundas transformações em termos epistemológicos, cujos rumos e implicações são imprevisíveis. Segundo o psicólogo, tanto pode ser vista como produto de um gênio excêntrico, quanto pode ser concebida como um conjunto de noções passíveis de uma tradução de acordo com "um esquema conceitual inteligível dentro das noções consagradas da psicologia":

Nessa perspectiva de conceber o problema, pode-se notar a considerável similaridade entre a forma como Erickson lidava com seus pacientes e, talvez sem que o soubesse, a forma como se posicionou diante dos próprios paradigmas dominantes na psicologia. Ao invés de confrontar abertamente suas crenças e ativar suas resistências, em sua prática terapêutica e hipnoterapêutica ele procedia de forma indireta desviando sua atenção e ativando aos poucos, via inconsciente, seus processos de mudança (Erickson e Rossi, 1979; Erickson, Rossi e Rossi, 1976; Haley, 1991; Zeig e Geary, 2000). De modo semelhante, seu legado estético e pragmático, ao mesmo tempo em que evoca profunda admiração e curiosidade da comunidade científica, parece promover em seu seio, sem que se perceba, importantes modificações que questionam profundamente os pressupostos da psicologia clínica (NEUBERN, 2002, p. 364).

Neubern se vale da metáfora do cavalo de Tróia para apresentar o novo paradigma ericksoniano, afirmando tratar-se de

[...] um presente belo e imponente que, ao cair da noite e já no interior das muralhas do saber, anula suas defesas, permitindo a revolução e a construção de uma nova ordem. Contudo, parte-se do pressuposto de que o momento atual do conhecimento científico, particularmente em psicologia, é o dessa noite confusa e tumultuada, própria das crises paradigmáticas, cujo alvorecer ainda parece distante, pois as próprias surpresas presentes no interior do cavalo de Erickson ainda não se mostraram por inteiro (NEUBERN, 2002, p. 364). 
O autor enfatiza a busca da Psicologia em afirmar-se como Ciência de acordo com os sistemas estabelecidos no Ocidente nos últimos séculos, que privilegiavam a racionalidade e a objetividade visando conceber "realidades únicas, exclusivas e universais", que permitissem previsão e controle, colocando à margem a questão da subjetividade. E é justamente essa questão que Erickson insere no cenário da Psicologia, recebida com um misto de desconfiança e encantamento:

Neste contexto, tal como ocorrido na guerra de Tróia, os psicólogos
recebem a obra de Erickson em meio à profunda admiração, sem
vislumbrar os perigos que comporta contra suas construções
teóricas. A ebriedade das festas e comemorações das pretensas
vitórias de sua cientificidade parece tê-los embalado na doce ilusão
de enquadrá-la em perspectivas tradicionais, reconhecidas por suas
respectivas comunidades. É assim que sua forma não convencional
de terapia é associada ao humanismo, ao behaviorismo e à
psicanálise (Chertok, 1998), como também às teorias sistêmicas
(Haley, 1991; Hoffman, 1992). Entretanto, em seu seio, a obra de
Erickson parece guardar um ataque contundente contra o pilar
universal e generalista das construções teóricas (NEUBERN, 2002,
p. 365). O sujeito objetivado da Ciência tal como mencionada acima, é submetido a um processo complexo, de múltiplas disjunções e reduções, marcado por articulações com seus próprios sistemas internos e com os sistemas sociais, passando por

[...] um conjunto de procedimentos que o atomizam, isolando-o de suas conexões e momentos históricos, o esgotam em outra dimensão (como a biologia ou a linguagem) ou o relacionam isomorficamente com números ou respostas comportamentais, desconsiderando as propriedades autoreguladoras (sic!) dos processos subjetivos que integra (NEUBERN, 2002, p. 367).

Ao ser assim descaracterizado como sujeito, o objeto de estudo em questão visava a adaptar-se aos conteúdos a priori e universais que "frequentemente faziam mais sentido ao corpo teórico do que aos cenários próprios dos sujeitos”, sofrendo, não raro, "intensa marginalização, colocando-se como terrenos proibidos ou míticos para a investigação científica", como no caso da hipnose (NEUBERN, 2002).

A abordagem estratégica traz à tona a complexa questão da subjetividade, "promovendo articulações entre noções classicamente opostas pelo paradigma dominante." Erickson declara as dificuldades de ter como objeto de trabalho um sujeito em constante mutação, que apresenta significativas mudanças ao longo do tempo - embora parta de um pressuposto background genérico, que lhe serviria 
como base -, além de estabelecer uma relação entre a ação do sujeito e seu contexto histórico, preconizando "um sujeito atual e auto-regulado (sic!) que qualifica de forma própria as influências sociais e históricas sem colocar-se como um autômato das mesmas" (NEUBERN, 2002, p. 368).

Cabe destacar que a ênfase de sua orientação, na maioria dos casos, não evocava o passado de seus pacientes nem criava um vínculo causal ou linear na relação temporal. Ao contrário, trabalhava com elementos e fatos do presente, criando um contexto para a mudança, visando a um futuro próximo (LANKTON, s/d).

Neubern (2002) destaca que, mesmo havendo essa possibilidade de retorno ao acontecimento, é possível dele extrair, a partir de um jogo dialético que Erickson estabelece em relação a seu paciente, novos significados que se apresentam como alternativas ao determinismo psicológico e histórico que podem exercer influência sobre a produção de sintomas, sem esgotá-la.

Além disso, na terapia estratégica, várias expressões do sujeito são observadas: não apenas as verbais, como também as não-verbais - respiração, postura, expressão facial, vestimentas, dentre outras:

Tal observação que busca atender ao mesmo tempo à (sic!) uma visão holística, singular e momentânea do sujeito refere-se ao que Erickson designou como minimal cues (Erickson, 1964; Erickson e Rossi, 1979) e remete à exigência de qualificação (ou utilização) das diversas expressões do sujeito sem a necessidade de enquadrá-las em uma dada perspectiva teórica. A relevância deste ponto refere-se à possibilidade de conceber o processo interativo (seja da terapia, da pesquisa ou da própria construção do conhecimento) com uma infinidade de pontos (minimal cues) que conferem a tal processo momentos, rupturas e aberturas. A história desenvolvida, importante para a consideração dessas interações, parte de uma perspectiva linear e homogênea para uma perspectiva múltipla, heterogênea e com diversas possibilidades de significação e narrativa (NEUBERN, 2002, p. 368).

O sujeito, assim observado, tem seus próprios cenários valorizados pelo terapeuta, que se volta para o desencadeamento de mudanças a partir dos processos particulares do paciente e não a partir de conteúdos universais e a priori. Essa perspectiva pragmática cria condições para que o sujeito participe efetivamente, em consonância com seus próprios projetos de mudança. A valorização da subjetividade possibilitaria "a criação de espaços epistemológicos para o sujeito do cotidiano, livre das amarras das superestruturas inconscientes e sociais, pronto para viver seus 
próprios dramas em seus cenários sociais, ao invés de viver os dramas de Édipo em seu cenário teórico e artificial”, remetendo a um confronto direto com o paradigma dominante para quem a subjetividade constituiu, nos últimos séculos, uma terrível ameaça (NEUBERN, 2002).

Neubern observa que o novo paradigma ericksoniano apresenta como desafios a dificuldade de uma construção teórica, a subjetividade como objeto complexo, além do que denominou "a busca de novas racionalidades", que declara figurar como uma de suas maiores contribuições:

Sua insistência em não construir sistemas condizentes com a tradição psicológica é altamente significativa, pois diante de uma realidade altamente complexa, Erickson prefere contemplá-la e respeitá-la, posto que qualquer forma de teorização conhecida o levaria aos mesmos equívocos de seus contemporâneos, isto é, à uma profunda mutilação e descaracterização dos objetos de estudo. Ao limitar-se a construir alguns princípios de abordagem, ele não só apontava para a necessidade de respeito das realidades subjetivas, mas também para a necessidade de investigações e desenvolvimentos epistemológicos mais profundos que pudessem contemplar e abordar semelhante complexidade (NEUBERN, 2002, p. 369).

Corroborando com esse pensamento, Lankton afirma que

Uma epistemologia orientada para a mudança indica que os terapeutas ativos têm algumas características que os separam dos terapeutas tradicionais do último século. A terapia moderna se apoia numa epistemologia que operacionaliza como as pessoas mudam, não tenta explicar a verdade nem a causalidade. É um enfoque de terapia ativa que constrói a base para os recursos para levar às metas desejadas. Terapeutas e clientes cooperam na construção de uma percepção de experiências e na compreensão de seus significados (LANKTON, s/d).

Lankton (s/d) aponta quatro aspectos da terapia estratégica de Erickson que assinalam a diferença entre a epistemologia tradicional e a que chamou "emergente", especialmente no que se refere ao uso das sugestões. São eles:

1. O propósito e uso da sugestão - Lankton observa significativas mudanças na maneira como Erickson tratou a sugestão, ao longo dos anos, como ferramenta para alcançar os fins desejados no tratamento de seus clientes. Exemplifica citando uma transcrição de um atendimento datada de 1945, em que Erickson usa redundantemente a palavra "durma", repetindo diversas 
vezes a frase "Agora quero que durma mais e mais profundamente", afirmando ainda: "Posso colocá-lo em qualquer nível de transe". Para Lankton, essa postura indica quão diretivo era o trabalho de Erickson na ocasião. Já em 1976, afirma, Erickson passa a valorizar a sugestão indireta, deixando de lado a posição de um "expert autoritário" para se colocar frente ao cliente como alguém que "oferecia" ideias e sugestões.

2. A metáfora como intervenção indireta - Nas décadas de 40 e 50, segundo Lankton, Erickson preferia usar ambiguidades em sua clínica terapêutica para que os clientes desenvolvessem suas próprias respostas singulares. A partir daí, foi desenvolvendo "histórias fabricadas", tendo, em 1979, publicado um artigo com Rossi em que apresenta formalmente o valor da metáfora como forma de intervenção indireta.

3. O significado de um sintoma - Lankton assinala as mudanças de concepção de Erickson em relação aos sintomas destacando que, em 1954, Erickson afirmava que o desenvolvimento dos sintomas neuróticos constituía comportamento de caráter "defensivo e protetor", de acordo com a concepção analítica tradicional de conceitos como "defesa e ataque". Em 1966, já vislumbrava os sintomas da doença mental como uma "ruptura na comunicação entre as pessoas". E em 1979, concluiu que tais sintomas eram "formas de comunicação" e "sinais de problemas no desenvolvimento que estão no processo de se tornarem conscientes". Tal conclusão, segundo Lankton, é muito mais coerente com as ideias expressas verbalmente por Erickson em vários de seus atendimentos que demonstravam que ele não se apoiava numa teoria da personalidade, mas "inventava" uma teoria para cada paciente, em particular.

4. Aquilo que constitui uma cura - No que se refere à cura, segundo Lankton, as ideias de Erickson permaneceram as mesmas do início ao fim de sua carreira. Já nos idos de 1948, afirmara que a cura não era resultado de uma sugestão, mas um desenvolvimento a partir da ressignificação da experiência.

Os critérios ora apresentados explicitam como as técnicas terapêuticas de Erickson se enquadram num enfoque epistemológico. A partir destes destaques, Lankton conclui: 
Embora tenha me concentrado nas intervenções de Erickson para ilustrar sua posição, seu trabalho frequentemente foi um exemplo fundamental da mudança do paradigma da psicologia para a moderna epistemologia. As ramificações dessa mudança de paradigma são tremendamente amplas e importantes (LANKTON, $\mathrm{s} / \mathrm{d})$.

Lankton afirma que muitos terapeutas poderiam escolher empregar uma metáfora a prescrever uma medicação. No entanto, há os que não tenham criatividade suficiente para fazê-lo - gostariam de dispor de um "glossário de metáforas" para poder usá-las. Assim, preferem empregar técnicas que acenem com a promessa de resultados terapêuticos prontos. Diferentemente, Erickson propõe uma abundância de intervenções para cada paciente sem muito esforço por parte do terapeuta, como será discutido a partir do capítulo 3.

O autor afirma que alguns dos traços distintivos da terapia e das intervenções associadas ao trabalho de Erickson são importantes não por sua "nãoconvencionalidade", mas por funcionarem como um veículo para unir terapeuta e cliente num processo de co-criação de um contexto para a mudança.

Resumidamente, é possível destacar, além dos quatro aspectos constitutivos de novos paradigmas propostos por Lankton, os seguintes, a partir da visão ericksoniana, frente à Psicologia como hoje se apresenta, conforme o quadro a seguir: 


\begin{tabular}{|c|c|}
\hline $\begin{array}{l}\text { PARADIGMAS TERAPÉUTICOS } \\
\text { DA PSICOLOGIA TRADICIONAL }\end{array}$ & $\begin{array}{l}\text { PARADIGMAS TERAPÉUTICOS } \\
\text { DA PSICOLOGIA ERICKSONIANA }\end{array}$ \\
\hline $\begin{array}{l}\text { Confronto aberto das crenças do cliente, } \\
\text { ativando suas resistências }\end{array}$ & $\begin{array}{l}\text { Desvio da atenção do cliente em relação } \\
\text { ao problema, ativando, via inconsciente, } \\
\text { processos de mudança }\end{array}$ \\
\hline $\begin{array}{l}\text { Busca de realidades únicas, exclusivas, } \\
\text { universais }\end{array}$ & $\begin{array}{l}\text { Busca de soluções individuais, para cada } \\
\text { cliente }\end{array}$ \\
\hline $\begin{array}{l}\text { Sujeito objetivizado, submetido a um } \\
\text { processo complexo de múltiplas } \\
\text { disjunções e reduções, marcado por } \\
\text { articulações com seus próprios sistemas } \\
\text { internos e com os sistemas sociais }\end{array}$ & $\begin{array}{l}\text { Sujeito subjetivizado,visto sob a ótica de } \\
\text { um background, que lhe serve como } \\
\text { base, a partir do qual se estabelece uma } \\
\text { relação entre a ação do sujeito e seu } \\
\text { contexto histórico }\end{array}$ \\
\hline Foco no passado do sujeito & Foco no presente e futuro do sujeito \\
\hline $\begin{array}{l}\text { O terapeuta não intervém diretamente no } \\
\text { processo de mudança do sujeito }\end{array}$ & $\begin{array}{l}\text { O terapeuta intervém diretamente no } \\
\text { processo de mudança do sujeito }\end{array}$ \\
\hline Foco na linguagem verbal & Foco também na linguagem não-verbal \\
\hline
\end{tabular}

\section{Quadro 2 - Paradigmas terapêuticos da Psicologia tradicional x Paradigmas terapêuticos da Psicologia ericksoniana}

Visando inserir a grande narrativa de Erickson no quadro da Psicologia atual, este estudo se propõe a investigar as regularidades dos padrões de linguagem ericksonianos em seus atendimentos por meio de uma abordagem empírica, através de um método capaz de ser aprendido e replicado.

Segundo Piaget (1974), a aprendizagem pode gerar conhecimento, conforme suas próprias palavras:

[...] a aprendizagem pode dar origem à formação de saberes empíricos, fatos de constatações sem razão, admitidos mas não compreendidos, e cuja razão é não somente de se limitar às situações observadas, mas ainda de se perder rapidamente;mas pode também dar lugar a estruturações cujos resultados são duráveis e generalizáveis (PIAGET, 1974, p. 228-229).

As análises empíricas de alguns casos clínicos de Erickson, apresentadas no capítulo 4 desta tese, representam um primeiro passo na direção de uma metodologia que possa estimular a aprendizagem da aplicação do Modelo Milton, visando, futuramente, à geração de conhecimento capaz de inscrever a narrativa ericksoniana no quadro da Psicologia como atualmente se apresenta. 
Conforme visto neste capítulo, Erickson se destaca por apresentar significativas mudanças quanto ao uso da hipnose e da linguagem, trazendo uma importante e efetiva contribuição para a terapia estratégica, bem como apresentando novos paradigmas terapêuticos baseados em suas práticas clínicas. 


\title{
2. HIPNOSE: DE FREUD A ERICKSON
}

\begin{abstract}
Realmente, a hipnose é um fenômeno comum em toda vida humana. Qualquer um que possa comunicar-se pode aprender a usá-la.
\end{abstract}

MILTON ERICKSON

Como a hipnose é um método radicalmente identificado com a terapia estratégica ericksoniana, o objetivo desta tese não poderia ser cumprido se não fosse dedicada uma parte dela ao estudo da hipnose.

Segundo Erickson (ERICKSON; HERSHMAN; SECTER; 2003), "o hipnotismo é tão velho quanto o tempo e provavelmente tenha se originado quando o primeiro homem arrastava-se na lama primitiva." Há 2000 anos, sacerdotes gregos e egípcios empregavam a hipnose no tratamento de várias doenças. Para induzir estados de transe semelhantes aos da hipnose, povos primitivos empregavam a batida ritmada de tambores, bem como danças ritualísticas; no Oriente, a ioga obtinha respostas fisiológicas do corpo, suscitando os mesmos efeitos, mediante exercícios de respiração e postura. Na Idade Média, a cura divina também promovia estados alterados de consciência em indivíduos sugestionáveis, ávidos pelo "toque real" de alguma figura sagrada que os livrassem de seus males. A partir da hipnose tal como será descrita no próximo tópico, Erickson foi capaz de extrair dela o sumo essencial: o estado hipnótico, substituindo, ao longo dos anos, o transe tradicional, pela sugestão indireta e outras técnicas integrantes da chamada hipnoterapia ericksoniana, como será visto ao final deste capítulo.

\subsection{Apanhado histórico sobre as teorias da hipnose ${ }^{9}$}

A história moderna da hipnose tem lugar a partir de 1773, com o médico alemão Franz Mesmer. Trabalhando em Viena com o sacerdote jesuíta e astrônomo Maximiliam Hell, juntos criaram um tratamento à base de ímãs para casos de

\footnotetext{
${ }^{9}$ Baseado nos autores apontados por Erickson como relevantes no capítulo 1 de seu livro Hipnose médica e odontológica.
} 
histeria. Hell acreditava que os magnetos curavam por suas propriedades físicas; Mesmer, porém, atribuía as curas a algum tipo de fluido, que chamou de "magnetismo animal" para diferenciar do magnetismo mineral.

Em 1775, Mesmer travou contato com o padre Johann Joseph Gassner, que obtinha curas pela imposição das mãos. Para Mesmer, tratava-se de uso evidente do magnetismo animal; passou então a aprimorar a técnica de Gassner, acreditando que o tal "fluido", agindo sob a influência de forças magnéticas oriundas de corpos astrais, seria capaz de curar.

Por volta de 1778, Mesmer mudou-se para Paris, desenvolvendo a "cuba de Mesmer", dispositivo guarnecido com metais e ímãs, no qual clientes eram imersos buscando a cura para diversos males. Mais tarde, começou a atribuir a si próprio poderes especiais, divulgando a ideia de que raios magnéticos fluíam de seus dedos, promovendo as curas até então consignadas ao magnetismo.

Ante o fato, a Academia Francesa designou uma comissão formada por Benjamin Franklin, Antoine Laurent de Lavoisier e Joseph Ignace Guillotin para investigar Mesmer, concluindo que os efeitos atribuídos ao magnetismo animal resultavam da imaginação do cliente, uma vez que muitos deles, mesmo quando submetidos a objetos não-imantados, apresentavam convulsões quando os tocavam. Assim, o médico foi denunciado por fraude, deixando de lado sua pesquisa. No que se refere a este episódio, Erickson (2003, p. 20) observa que "aqueles cientistas falharam por não perceber que as sugestões resultantes de um intenso rapport, eram realmente as responsáveis por aquelas curas". Note-se que o rapport tornou-se um instrumento altamente valorizado por Erickson em seus atendimentos para a obtenção dos resultados almejados junto a seus clientes.

Embora desacreditado, Mesmer amealhou seguidores. Em 1841, o cirurgião inglês James Braid, inicialmente avesso às práticas do mesmerismo, interessou-se pelo assunto. Assim, desenvolveu a técnica de fixação visual à chama de uma vela para induzir estados de relaxamento, que chamou de hipnose. A palavra deriva de hypnos, do grego, sono; mais tarde percebeu seu erro, ao observar que o transe não induzia propriamente ao sono tal como o vivenciamos, e tentou adotar o termo monodeísmo - que significa concentração numa única idéia -, mas este não vingou. 
Alguns anos antes, em 1838, o professor de medicina da Universidade de Londres, John Elliotson, dedicou seus estudos ao mesmerismo, sendo convidado a se retirar da vida acadêmica, tal como ocorrera com Mesmer. Apesar disso, em 1884, criou a revista Zoist, especializada no assunto.

Da mesma época destaca-se ainda, em 1845, o cirurgião escocês James Esdaile especialista no uso da anestesia mesmérica, autor do clássico Mesmerismo na Índia, publicado em 1850, em que descreve muitos dos fenômenos hipnóticos tais como são conhecidos na atualidade, empregados em 250 cirurgias realizadas na Índia, algumas das quais Erickson aponta como "formidáveis" - amputação de perna, remoção de tumores na próstata, amputação de pênis.

Embora seus casos tenham sido documentados e observados por médicos e autoridades locais, de volta à Inglaterra, Esdaile teve seu trabalho ridicularizado e relegado ao ostracismo por seus colegas. Mudou-se então para a Escócia, onde seguiu empregando o método eventualmente, lamentando as dificuldades encontradas para convencer os colegas e a opinião pública sobre a eficácia da hipnose - fato endossado por Erickson em seu tempo.

À época, o médico francês Ambroise-Auguste Liébault, inspirado por Braid, também manifestou interesse por hipnose, trabalhando sem remuneração com as técnicas, para evitar ser considerado charlatão. Os resultados de seu trabalho foram divulgados por Hyppolyte Bernheim, que lhe enviou um cliente que sofria de ciática, de quem cuidara por seis anos sem sucesso, e que foi curado por Liébault após algumas sessões de hipnose. A partir daí, ambos iniciaram um trabalho conjunto, tratando cerca de dez mil clientes, dando origem à mais tarde denominada "Escola de Nancy", marco da hipnose moderna. Em 1884, Bernheim escreve seu primeiro tratado científico sobre hipnose, De la suggestion dans l'etat hypnotique, mais tarde prefaciado por Freud, em sua versão alemã.

Jean-Martin Charcot também inscreveu seu nome na história da hipnose, especialmente a partir de 1862, quando passou a trabalhar no hospital para doentes mentais Salpêtrière, dando especial atenção aos transes, que considerava uma forma de histeria. Retomando a teoria do magnetismo animal defendida por Mesmer, alimentou o antagonismo da Escola de Nancy em relação a suas ideias. Charcot promovia a indução dos sintomas histéricos em clientes normais sob efeito de sugestão hipnótica e defendia que as ideias influenciavam a determinação desses 
sintomas e de outras doenças nervosas. Figura carismática, Charcot influenciou fortemente as pesquisas de Freud em relação à hipnose, tendo seus princípios sobrepujados por aqueles apresentados por Liébault e Bernheim no entendimento do pai da psicanálise.

Contemporâneo e colaborador de Charcot, Pierre Janet, neurologista francês que concluiu seu doutorado em Psicologia no ano de 1889, apresentou em sua tese sobre o automatismo psicológico alguns conceitos que mais tarde viriam a ser apropriados por Freud, como o da segunda consciência - que corresponderia, na prática, à idéia de inconsciente. De acordo com sua teoria, um trauma severo, como um ataque histérico, por exemplo, acarretaria a dissociação da consciência. $E$ a segunda consciência, também chamada consciência hipnóide organizada, controlaria o indivíduo, "anulando o poder das ideias".

Erickson (2003) observa que a teoria de Janet falha ao não dar conta de explicar outros tipos de comportamento de clientes hipnotizados, uma vez que nem todos são dissociados e que a hipnose pode ser induzida por meio de outras modalidades sensoriais além das palavras, tais como "estímulos não-verbais, extraverbais e intraverbais ou demais processos de comunicação" que constituem mecanismos de feedback. Ao longo de sua carreira, como visto no capítulo 1, Erickson se vale cada vez mais das sugestões indiretas em substituição ao transe clássico. Isto constitui um dos principais diferenciais entre seu trabalho e o de Freud quanto ao uso da hipnose, como será visto a seguir.

Sigmund Freud escreve se insere na história contemporânea da hipnose a partir de seus conceitos clássicos, uma vez que, através de seu envolvimento com o transe hipnótico - e posterior abandono - obteve subsídios para a elaboração dos princípios da Psicanálise.

\subsection{Freud e a hipnose}

No que se refere a seu envolvimento com a hipnose, é importante destacar que Freud estudou com Jean-Martin Charcot no início de sua carreira, nos idos de 1885. Nutria pelo consagrado hipnotista francês grande admiração, considerando-o um modelo de cientista para si próprio, especialmente pelo fato de Charcot ater-se mais 
aos "fatos" - a prática ante os acontecimentos - do que propriamente à teoria, conforme relata Gay:

O que mais interessava a Freud era que seu modelo [Charcot] se dispunha claramente a levar a sério o comportamento bizarro de seus pacientes, aprestando-se (sic) também a alimentar estranhas hipóteses. Ao dar a mais cuidadosa e percuciente atenção a seu material humano, Charcot era um artista e, segundo ele mesmo, um visuel - "um homem que vê". Confiando no que via, ele defendia a prática acima da teoria; uma observação que fez em dada ocasião imprimiu-se com ferro ardente na mente de Freud, La théorie, c'est bom, mais ça n'empêche pas d'existir. Freud nunca esqueceu esse bon mot, e anos depois, ao transtornar o mundo com fatos incríveis, nunca se cansava de repeti-lo: a teoria está muito bem, mas isso não impede que os fatos existam. Foi a principal lição que Charcot tinha a transmitir: a obediência submissa do cientista aos fatos não é a adversária, mas a fonte e a servidora da teoria (GAY, 1989, p. 62-64).

Freud adotou a hipnose dentre seus procedimentos terapêuticos, tornando-se, à época, defensor do método. No prefácio à tradução da primeira edição da obra De la sugestion, de H. Bernheim (1888), afirma:

Há cerca de dez anos, a opinião corrente na Alemanha ainda era a de por em dúvida a realidade dos fenômenos hipnóticos e procurar explicar os relatos referentes a eles como devidos a uma combinação de credulidade por parte dos observadores e simulação por parte das pessoas submetidas às experiências. Atualmente, essa posição já não é mais defensável, graças aos trabalhos de Heidenhain e Charcot para mencionar apenas os maiores nomes dentre aqueles que deram seu irrestrito apoio à realidade do hipnotismo (FREUD, 1998, p. 10).

Direcionando o foco de seus experimentos hipnóticos à histeria, no referido prefácio questiona a tese do "grand hypnotisme" sustentada por Charcot, ante o "pequeno hipnotismo" apoiado na sugestão e no psiquismo, apresentado por Bernheim.

Segundo Charcot, a hipnose só poderia ser aplicada a clientes histéricos (GAY, 1989), provocando fenômenos de ordem física ou fisiológica baseados "em deslocamentos da excitabilidade no sistema nervoso, que ocorrem sem a participação das partes do mesmo que operam com a consciência" (FREUD, 1998, p. 11). Tomando por base o "grande hipnotismo", Freud recomenda que a escola de Charcot se dedique a provar essa tese de forma inequívoca:

Uma vez demonstrada a existência de fenômenos fisiológicos, objetivos, na histeria, já não há mais nenhuma razão para abandonar a possibilidade de que um "grande" hipnotismo histérico chegue a 
apresentar fenômenos que não derivam da sugestão por parte do pesquisador. Se tais fenômenos de fato ocorrem, isto é uma hipótese que deve ser deixada para uma investigação à parte, que tenha esse fim em vista. Assim, cabe à escola do Salpêtrière provar que os três estágios da hipnose histérica podem ser inequivocadamente (sic!) demonstrados mesmo numa pessoa que vem para a experiência sem qualquer influência prévia e mesmo quando o pesquisador mantém a conduta mais escrupulosa; e, sem dúvida, tal prova não há de demorar. Pois já a descrição do grande hipnotismo apresenta sintomas que vão muito nitidamente contra a possibilidade de serem considerados psíquicos (FREUD, 1998, p. 14).

Mesmo concordando com a ocorrência de fenômenos fisiológicos, Freud passa a considerar também a importância do psiquismo, conforme sustentado por Bernheim, em relação à hipnose:

Assim, os fenômenos fisiológicos efetivamente ocorrem, pelo menos no grande hipnotismo histérico. Mas, no pequeno hipnotismo normal, que, conforme insiste apropriadamente Bernheim, tem maior importância para nossa compreensão do problema, toda manifestação - assim se afirma - surge por meio da sugestão, por meios psíquicos (FREUD, 1998, p.15).

Em meio às constatações de Charcot e ao pensamento de Bernheim, sugere que se busque um elo capaz de unir as duas correntes:

[...] devemos concordar com Bernheim em que a divisão dos fenômenos hipnóticos em fenômenos fisiológicos e fenômenos psíquicos deixa muito a desejar: precisa-se urgentemente de um elo que vincule as duas espécies de fenômenos. A hipnose, seja ela produzida de uma forma ou de outra, é sempre a mesma e mostra os mesmos aspectos (FREUD, 1998, p. 16).

No ano seguinte, 1889, na resenha sobre o livro $\underline{\text { Hipnotismo }}^{10}$, de August Forel, Freud insiste na importância da hipnose como método terapêutico:

Realmente, há numerosos adversários da hipnose que formaram seu julgamento de um modo mais apressado. Não puseram à prova o novo método terapêutico e não $o$ empregaram imparcial $e$ cuidadosamente, como se procederia, por exemplo, com uma droga recentemente recomendada: rejeitaram a hipnose a priori, e agora a ausência de conhecimentos dos valiosos efeitos terapêuticos desse método não os autoriza, seja qual for o seu fundamento, a manifestar tão cáusticas e injustificadas expressões de antipatia à hipnose. Exageram enormemente os perigos da hipnose, passam a destratála sistematicamente e, diante da abundância de relatos de cura pela hipnose, que já não podem ser relegadas ao descaso, reagem com

\footnotetext{
${ }^{10}$ Publicada em 1889.
} 
esses pronunciamentos oraculares: "As curas nada provam, elas mesmas exigem prova" (FREUD, 1998, p. 24).

No mesmo texto, Freud declara suas expectativas quanto ao "triunfo do tratamento sugestivo" na Alemanha e em Viena (sic), triunfo este então alcançado em outros países. E queixa-se de que as críticas voltadas à hipnose, na verdade, referem-se também à sua própria terapia.

Recomenda à classe médica que utilize a hipnose para evitar que seus clientes sofram, uma vez que o "uso inócuo da influência psíquica" poderia produzir-lhes alívio. Ademais, considera que nem a hipnose nem as sugestões aplicadas após se alcançar tal estado possam ser consideradas ações prejudiciais aos clientes.

Em outro trecho, Freud coloca-se frontalmente favorável à hipnose, dirigindo seu discurso àqueles "que se habituaram a deixar que seu julgamento sobre matérias científicas seja determinado por uma grande autoridade", sem levar em conta seu próprio discernimento, elencando, a seguir, uma série de cientistas da época que adotaram a hipnose em seus procedimentos, tais como Meynert, H. Obersteiner, Krafft-Ebing, além do próprio Forel.

No artigo Hipnose, de 1891 (FREUD, 1998), declara que "seria um equívoco pensar que é muito fácil praticar a hipnose com fins terapêuticos. Pelo contrário, a técnica de hipnotizar é um método médico tão difícil como qualquer outro" (destaque da Autora). Enfatiza a necessidade de tratar-se o método com seriedade - o médico que quiser se dedicar a essa arte, deve tê-la aprendido com um mestre e tê-la praticado bastante. Recomenda que a hipnose não seja praticada com ceticismo e que aqueles que venham a praticá-la não se sintam feridos em sua dignidade médica, uma vez que já estariam convencidos, por sua experiência e bagagem teórica, da realidade e da importância da influência hipnótica.

No entanto, enfatiza a resistência da classe médica ao uso da técnica destacando, num outro trecho:

Devido a antipatia ao tratamento hipnótico verificada no momento, raramente podemos empregar a hipnose, exceto quando todos os outros tipos de tratamento foram tentados sem êxito. Isto tem sua vantagem, pois assim ficamos conhecendo a verdadeira área de ação da hipnose. Naturalmente, também podemos hipnotizar com vistas ao diagnóstico diferencial: por exemplo, quando estamos em dúvida se determinados sintomas se relacionam com a histeria ou com uma doença nervosa orgânica. Contudo, essa prova só tem 
algum valor em casos nos quais o resultado é favorável (FREUD, 1998, p. 38).

Em 1883, figurando ainda como defensor da hipnose, Freud publica, em parceria com o médico e fisiologista austríaco Josef Breuer, a Comunicação Preliminar ${ }^{11}$, em que descrevem suas práticas relacionadas à técnica com a finalidade de estudar as formas e sintomas relacionados à histeria:

Via de regra, é necessário hipnotizar o paciente e provocar, sob hipnose, suas lembranças da época em que o sintoma surgiu pela primeira vez; feito isso, torna-se possível demonstrar a conexão causal da forma mais clara e convincente.

Esse método de exame tem produzido, num grande número de casos, resultados que se afiguram valiosos tanto do ponto de vista teórico como do ponto de vista prático (BREUER; FREUD, 1883, p. 21).

Ainda quanto à eficácia da hipnose, os autores declaram que experiências ausentes na lembrança dos clientes quando em estado psíquico normal, emergem com a nitidez de um fato recente, após serem submetidos à técnica, especialmente no que se refere aos traumas que originavam fenômenos histéricos.

Breuer e Freud (1883) destacam dois grupos distintos de condições em que a hipnose poderia beneficiar seus clientes. No primeiro, encontram-se casos em que os clientes não reagiriam a um trauma porque a natureza do mesmo não comportava reação - como no caso da perda de um ente querido ou ante circunstâncias sociais que impossibilitassem a reação; ou ainda em função de um recalque consciente, mediante o qual a pessoa inibiria ou mesmo suprimiria a lembrança do fato.

Um segundo grupo de condições é determinado pelos estados psíquicos em que o cliente foi submetido ao fato - não pelo fato em si. De acordo com os autores, sob hipnose, seria possível detectar

[...] as causas dos sintomas histéricos, representações que em si mesmas não são importantes, mas cuja persistência se deve ao fato de que se originaram durante a prevalência de afetos gravemente paralisantes, tais como o susto, ou durante estados psíquicos positivamente anormais, como o estado crepuscular semi-hipnótico dos devaneios, a auto-hipnose, etc. Em tais casos, é a natureza dos estados que torna impossível uma reação ao acontecimento. É claro que ambas as espécies de condições podem estar presentes ao mesmo tempo, e isso de fato ocorre com frequência. É o que

\footnotetext{
${ }^{11} \mathrm{Na}$ Comunicação Preliminar, Breuer e Freud relatam o caso "Anna O.", considerado o estudo que, mais tarde, inspirou Freud na concepção da teoria da Psicanálise.
} 
acontece quando um trauma que é atuante por si mesmo ocorre enquanto predomina um afeto gravemente paralisante, ou durante um estado de alteração da consciência. Mas também parece ser verdade que em muitas pessoas um trauma psíquico produz um desses estados anormais, o que, por sua vez, torna a reação impossível (BREUER; FREUD, 1883, p. 26-27).

Freud (1978) relata ter experimentado a eletroterapia na tentativa de ajudar as pessoas que sofriam de afecções nervosas, decepcionando-se com os resultados prometidos pelo método. Afirma também que Breuer apenas retomou seus experimentos empregando a hipnose, instigado pelo próprio Freud, enquanto este trabalhava com Charcot. No entanto, foi Breuer quem o motivou, mais tarde, a optar pela hipnose:

O tratamento pela sugestão durante a hipnose profunda, que aprendi através de impressionantes demonstrações de Liébault e Bernheim, parecia então oferecer um substituto satisfatório para o malogrado tratamento elétrico. Mas a prática de investigar pacientes em estado hipnótico, com a qual me familiarizou Breuer - prática que combinava um modo de agir automático com a satisfação da curiosidade científica - era, sem dúvida, incomparavelmente mais atraente do que as proibições monótonas e forçadas usadas no tratamento pela sugestão, proibições que criavam um obstáculo a qualquer pesquisa (FREUD, 1978, p. 41).

Durante o tempo em que trabalharam juntos, a hipnose era utilizada para conduzir a atenção do cliente a uma cena traumática a partir da qual o sintoma surgira, com o intuito de esclarecer qual o conflito mental ali envolvido, visando liberar a emoção reprimida.

Freud observa que as associações dos clientes os conduziam cada vez mais "para trás" - primeiro alcançando a puberdade, depois indo até à infância. Esse processo, que mais tarde recebeu o nome de regressão, tornou-se uma característica importante da análise. "Era como se a psicanálise não pudesse explicar nenhum aspecto do presente sem se referir a algo do passado; mais ainda, que toda experiência patogênica implicava uma experiência prévia que, embora não patogênica em si, havia, não obstante, dotado esta última de sua qualidade patogênica" (FREUD, 1978, p. 41).

A partir dessa observação, Freud passa a divergir em diversos pontos com Breuer quanto à validade do uso da hipnose, bem como em relação de alguns conceitos antes empregados em comum. Breuer enfocava aspectos fisiológicos da histeria, 
tentando explicar a divisão mental que ocorria nos clientes histéricos pela ausência de comunicação entre vários "estados de consciência" (jargão comum aos dois parceiros, na época), a partir dos quais construiu a teoria dos "estados hipnóides", que supostamente penetrariam na "consciência desperta" como corpos estranhos não assimilados. Enquanto isso, Freud considerava a divisão psíquica como efeito de um processo de repulsão, que denominou de "defesa", e tempos mais tarde, de "repressão". Segundo ele, houve, de sua parte, uma tentativa efêmera de trabalhar paralelamente com os dois mecanismos, o que não foi possível porque sua observação lhe mostrava sempre "uma única e mesma coisa", reforçando sua oposição à teoria hipnóide.

O rompimento com as ideias de Breuer, segundo Freud, não acarretou o rompimento de suas relações pessoais. "Este teve causas mais profundas, mas ocorreu de forma tal que de início não o compreendi; só depois é que, através de claras indicações, pude interpretá-lo", pontua (FREUD, 1978, p. 42). Uma das causas refere-se ao caso “Anna O.”, analisado por ambos na Comunicação Preliminar, em que Breuer afirmou que a questão da sexualidade não era relevante. Conforme relata:

No tratamento desse caso, Breuer usou, para com a paciente, de um rapport sugestivo muito intenso, que nos poderá servir como um perfeito protótipo do que chamamos hoje de "transferência". Tenho agora fortes razões para suspeitar que, depois de ter avaliado todos os sintomas de sua cliente, Breuer deve ter descoberto por outros indícios a motivação sexual dessa transferência, mas que a natureza universal deste fenômeno inesperado lhe escapoui, resultando daí que, como se tivesse sido surpreendido por um "fato inconveniente", ele tenha interrompido qualquer investigação subsequente.

Percebe-se que, a partir do rompimento com Breuer, tendo edificado as bases da teoria psicanalítica a partir dos mecanismos de regressão e de livre-associação, o interesse de Freud em relação à hipnose foi perdendo força, até esvanecer-se completamente. A descoberta da exploração do inconsciente descortinou novos horizontes para Freud, tão mais desafiadores que foram capazes de, organizados, gerar uma das mais importantes narrativas da Psicologia até os dias atuais. 


\subsection{Hipnose ericksoniana: para todos?}

Diferentemente de Freud, Erickson foi além dos princípios da hipnose clássica, criando um instrumental a partir dos efeitos hipnóticos promovidos na clínica terapêutica pela linguagem verbal e não-verbal, independentemente da indução tradicional ao transe hipnótico. A chamada hipnoterapia ericksoniana é um dos mais importantes legados de Erickson para a Psicologia contemporânea.

"Quer seja consciente ou inconscientemente, o homem usou sugestão e/ou hipnose muito antes que estivesse ciente dela", afirma Erickson (2003). Pessoas são hipnotizadas em suas vidas cotidianas sem se darem conta disso. Numa definição operacional, segundo suas próprias palavras:

[...] a hipnose pode ser vista como uma suscetibilidade ampliada para a sugestão, tendo como efeito uma alteração das capacidades sensoriais e motoras para iniciar um comportamento apropriado. A dificuldade com muitas teorias é que elas não distinguem o processo de indução do transe do fenômeno real, resultante do estado hipnótico. São entidades diferentes. Em hipnose, há interesse por um segmento ou fenômeno do comportamento que não pode ser separado do contexto do comportamento humano. (ERICKSON; HERSHMAN; SECTER, 2003, p. 25)

Um dos atendimentos clínicos mais famosos de Erickson data de 1945, quando o terapeuta demonstrou, para um pequeno grupo de colegas profissionais, sua abordagem singular em hipnoterapia no tratamento da "Srta. S". O caso ficou conhecido como "O Homem de Fevereiro", papel assumido por Erickson para entrar em contato com a jovem durante as quatro sessões realizadas. Nessas sessões, Erickson empregou recursos clássicos da hipnose como regressão, distorção de tempo, escrita automática e amnésia, entre outros, descritos adiante, para explorar a infância e a adolescência da paciente, visando proporcionar-lhe novos caminhos para sua personalidade adulta.

Embora, à primeira vista, esse consagrado caso de Erickson possa assemelhar-se ao famoso caso "Anna O." de Freud e Breuer, ali ficou evidente para estudiosos como Jerome Fink e Ernest Rossi - que organizou os registros das quatro sessões no livro "O Homem de Fevereiro" - que Erickson já acenava com importantes avanços quanto aos cânones da hipnose tradicional. Rossi (ERICKSON; ROSSI, 2003) destaca, dentre outros, o uso da hipnose como um processo ativo de trabalho 
interno, o uso da vinculação, o uso de perguntas e da confusão na orientação do tempo como diferenciais importantes da hipnose ericksoniana em relação à tradicional. Esses padrões apontados por Rossi nas quatro sessões do atendimento à "Srta. S.", mais tarde passaram a integrar o Modelo Milton, como será visto no Capítulo 3.

Haley (1991) afirma que a hipnose, tal como vista por Erickson, é "um processo entre pessoas, uma maneira pela qual uma pessoa se comunica com outra." Assim, a abordagem ericksoniana traz à tona o enquadramento interpessoal. Zeig (in ERICKSON; HERSHMAN; SECTER, 2003, prefácio, p. 9) destaca o modelo autoritário, comum à hipnose antes de Erickson, dirigida de fora para dentro (outside in), em que prevalecia a vontade do hipnotizador, que "implantava" sugestões diretas num sujeito passivo. "O trabalho de Erickson parte de dentro para fora (inside out) e métodos indiretos eram utilizados para despertar forças do cliente ao invés da aplicação de sugestões poderosas dirigidas contra um cliente passivo. Erickson formulou os conceitos centrais da hipnose moderna" (ZEIG in ERICKSON; HERSHMAN; SECTER, 2003, p. 9, prefácio), apresentados em 2.3.1.

Erickson afirma que o controle do comportamento pode ser obtido por recursos mecânicos, por meio de recompensas, pelo uso de punição, da razão ou da sugestão, sendo esta última a base para a hipnose, em parceria com a repetição. Segundo o autor, "tudo que se aprende num treinamento em hipnose pode ser considerado como modificações, amplificações, variações e explicações desses dois ingredientes básicos" - sugestão + repetição (ERICKSON; HERSHMAN; SECTER, 2003, p. 32). Como "amplificadores" dos efeitos hipnóticos, o autor aponta:

À sugestão e à repetição pode ser acrescentado o monodeísmo, que é a concentração em uma idéia para a exclusão de todas as outras, como foi sugerido por Braid, ou, em outras palavras, a eliminação de todos os estímulos externos exceto aqueles necessários para se iniciar o comportamento desejado. A eles podemos acrescentar a expectativa, a imaginação, a visualização e o prestígio do hipnotizador. Tudo isso representa uma parte importante na indução inicial da hipnose. Quaisquer fatores ou combinações desses fatores estão presentes na criação de um estado hipnótico (ERICKSON; HERSHMAN; SECTER, 2003, p. 32).

Sugestões não precisam, necessariamente, ser de natureza verbal, podendo ocorrer em qualquer nível sensorial, em especial os associados aos cinco sentidos: visão, audição, tato, paladar, olfato. Erickson era capaz de criar sugestões a partir do uso 
diferenciado de entonações ou de gestos, criando situações para espelhamento e rapport para entrar em sintonia com o cliente e melhor influenciá-lo, como apresentado na seção 3.2.3. Repetições são muito importantes em diversas aplicações como, por exemplo, na aprendizagem. As sugestões precisam ser aceitas pelo cliente, como explica Erickson:

O dicionário Webster define sugestão como a apresentação de uma idéia, impulso ou crença para a mente. Contudo, uma sugestão psicologicamente efetiva não deve ser apenas apresentada; ela deve ser aceita incondicionalmente - não incondicionalmente no sentido de algo que se aceita sem qualquer valorização crítica, mas sim com significado de favoravelmente, o que levará à iniciação do comportamento apropriado. Para ser efetiva a sugestão deve ser atuada pelo sujeito ou paciente, mesmo não havendo lógica para a sua aceitação (ERICKSON; HERSHMAN; SECTER, 2003, p. 33).

Erickson enfatiza ser a sugestibilidade algo normal para o ser humano, não devendo ser confundida com traço de idiotice:

Existe uma confusão frequente entre hipnotizabilidade e idiotice. Sugestibilidade pode ser definida como a aceitação não-crítica de uma idéia. "Não-crítico" não significa qualquer abandono de uma atitude crítica inteligente. Sugestibilidade também pode ser definida como a capacidade de uma pessoa responder a ideias. $\mathrm{Na}$ capacidade do indivíduo de responder, há necessariamente a implicação de que ele esteja utilizando todo o seu entendimento, crítico e associativo (ERICKSON; HERSHMAN; SECTER, 2003, p. $51)$.

Sugestibilidade é, pois, a aceitação não-crítica de uma idéia à qual a pessoa responde utilizando, implicitamente, todo seu entendimento crítico e associativo, sem abrir mão em nenhum momento de sua Inteligência. $O$ transe hipnótico não implica renúncia de vontade, prevalece nesse estado dual a cooperação entre sujeito e operador. Para tanto, é necessário, conforme dito anteriormente, que se estabeleça um contrato de confiança entre ambos, pois o transe hipnótico é um estado de consciência diferenciado; como destaca Erickson:

O primeiro sinal do transe hipnótico é a capacidade da pessoa de limitar sua maneira de pensar e sentir para sua vida conceitual, para imagens da memória, imagens visuais, imagens sensório-auditivas de todo tipo, É com sua vida conceitual, sua vida experimental, que ela tende a relacionar-se mais do que com realidades irrelevantes no seu ambiente comum (ERICKSON; HERSHMAN; SECTER, 2003, p. 52). 
Há transes leves, médios e profundos e estes se manifestam em formas desordenadas, o que pode dificultar a identificação dos mesmos para o hipnólogo aprendiz. Não se pode dizer que um seja superior a outro: "o único tipo de transe a ser pretendido é aquele que serve aos propósitos de um cliente específico ou sujeito experimental", afirma Erickson (2003, p. 53). Por isso, não há que se preocupar se a indução de um cliente resultar, aparentemente, apenas em transes leves ou médios, pois o aprendiz pode até mesmo induzir um transe profundo sem reconhecê-lo como tal. Da mesma forma, afirma Erickson (2003), após completar a indução, é possível que o aprendiz não saiba o que fazer com o estado de transe induzido: para melhor esclarecer este dilema, Erickson se vale de uma metáfora - se um homem viaja para algum lugar, qualquer que seja o seu destino, isto independe da viagem em si mesma e do que será feito ao alcançar seu destino. A viagem representaria a indução ao transe, o destino, o estado de transe; cabe ao hipnoterapeuta apresentar um roteiro de opções ao cliente, concluída a viagem.

Outra evidência do estado de transe é o estabelecimento de rapport entre sujeito e operador, por tratar-se de esforço conjunto em que a atenção de um se dirige ao outro - e assim reciprocamente - motivo pelo qual o cliente tende a se desligar temporariamente das situações do ambiente, dos estímulos externos, passando a responder somente ao operador. "Desligar-se temporariamente" não significa renúncia da vontade por parte do sujeito. Como Erickson (2003) exemplifica metaforicamente, uma pessoa não renuncia à sua vontade quando permite que outra dirija seu carro - pode haver cooperação e permissão dada à outra pessoa para que ela o faça. Trata-se de uma atribuição de papéis numa dada seleta situação.

No entanto, o rapport pode ser transferido de uma pessoa para outra: o operador, uma vez tendo constatado o efetivo rapport de seu cliente, pode solicitar a este que entre em rapport com outro alguém presente, que também poderia transferi-lo a outra pessoa, bem como mantê-lo com o operador original.

Transes hipnóticos podem conduzir a estados de catalepsia em que a tonicidade muscular causa paralisia temporária, situação análoga à dos animais assustados quando expostos a uma situação extrema de medo. Segundo Erickson (2003), nesses casos, o estado hipnótico pode ter origem atávica e muito embora o ser humano possua um córtex altamente desenvolvido, que torna desnecessários mecanismos de defesa tão radicais, a reação varia de indivíduo para indivíduo, o 
que também explica o fato de algumas pessoas serem mais facilmente hipnotizáveis que outras.

Outro fenômeno significativo, muitas vezes provocado pela hipnose, é a chamada atividade ideomotora - aquela em que o cliente é estimulado a realizar um movimento considerado normal fora do contexto que justificaria tal ação como, por exemplo, ser induzido a simular 0 ato de dirigir um carro, praticar movimentos relacionados a algum esporte ou mesmo escrever - este último conhecido como escrita automática.

Da mesma forma, pode ocorrer a chamada atividade ideossensora: experimentando um estado de torpor semelhante ao efeito anestésico, a pessoa é capaz de criar ou recriar uma imagem ou sensação abstraindo-a a partir de um estímulo real: por exemplo, "enxergar" a face da pessoa amada a partir da observação das chamas de uma lareira ou das nuvens no céu.

Alterações sensoriais podem ser produzidas nos campos visual, auditivo, gustativo, olfativo ou tátil e seus efeitos podem ser positivos ou negativos; tanto é possível "ver" algo que não está presente, como "deixar de ver" algo que se coloca concretamente à frente do cliente.

Outros fenômenos conhecidos da maioria das pessoas e que podem ser relacionados à hipnose: a amnésia, esquecimentos em geral temporários, que causam, por vezes, embaraços na vida real; a hiperamnésia, aumento da capacidade de lembrar; a supressão ou repressão de dados ou fatos; a distorção do tempo - em alguns minutos de transe é possível experimentar a sensação de se escalar uma montanha de 50m, por exemplo; a despersonalização, estado momentâneo de suspensão da própria identidade, como quando se está imerso, assistindo a um filme de ação e/ou suspense, esquecendo-se das sensações do ambiente, como a temperatura da sala ou mesmo as internas, como fome ou sede.

Vários estratagemas podem ser induzidos pelo operador como o sonambulismo, quando o sujeito entra num transe muito profundo, ou a dissociação, mediante a qual é possível ao cliente ver a si mesmo sentado do outro lado da sala. Para tanto, é recomendável que o operador tenha alguma experiência: "até que se tenha suficiente confiança, o aprendiz pode começar a hipnose disfarçadamente, com o 
pretexto de testar o cliente e então aprofundar respostas positivas, até que a hipnose seja efetivada", recomenda Erickson (2003, p. 37).

Quanto aos clientes considerados inaptos à prática, Erickson destaca: crianças por volta de 6 anos, adultos psicóticos, pessoas com problemas de retardamento mentais ou com inteligência abaixo da média. Segundo Erickson, tais pessoas têm dificuldade com o monodeísmo, a concentração em torno de uma idéia, não sendo, pois, cooperativas o suficiente para que o processo hipnótico alcance sua eficácia. Para alcançar o transe hipnótico, é preciso que a atenção do cliente seja dirigida a um fenômeno em particular, preferencialmente focado nos seus próprios conteúdos para que ele possa utilizar suas próprias capacidades para responder às idéias.

\subsubsection{Os dez princípios fundamentais da hipnoterapia ericksoniana}

Zeig (in ERICKSON; HERSHMAN; SECTER, 2003, prefácio) aponta, segundo sua própria visão, os dez postulados mais importantes da hipnoterapia ericksoniana que a distinguem da hipnose tradicional:

1. Uso da abordagem indireta - em vez de induzir diretamente um estado ("Enquanto conto até dez, seu braço fica cada vez mais pesado, até não poder se mover"), simplesmente sugerir ("Gostaria de saber como seria se você fosse sentindo seu braço ficar cada vez mais pesado até que não conseguisse mais movê-lo...").

2. Hipnose como jogo interacional - o transe interacional aprimorado por Erickson consiste numa comunicação bilateral: os clientes não apenas ouvem os comandos do operador, como dialogam com ele a maior parte do tempo, tornando possível calibrar e/ou redirecionar os efeitos desejáveis para a obtenção de respostas ante o problema apresentado.

3. Pequenas mudanças, passo a passo - Erickson trabalhava meticulosamente, convidando os clientes a cumprirem tarefas simples e prosaicas, que, ao final, resultavam em mudanças profundas. 
4. Foco no sintoma - as representações verbais e sensoriais do sintoma pelo cliente permitem que este seja transformado, melhorando seu estado geral sob um efeito "bola de neve".

5. Respeito ao cliente - atenção centrada no cliente. Erickson recomendava a seus terapeutas que se perguntassem "o que meu cliente quer fazer agora?" em vez de se perguntarem "o que eu, como terapeuta, devo fazer agora?". Extremamente confiante, Erickson "queria que seus clientes soubessem que eles poderiam realizar coisas, tal como desenvolver uma anestesia. A confiança e o interesse de Erickson na habilidade dos clientes em conseguir êxito, eram comunicados verbal e não verbalmente" (in ERICKSON; HERSHMAN; SECTER, 2003, prefácio, p. 11-12).

6. Hipnose como cooperação - a indução hipnótica era trabalhada no sentido de induzir à cooperação, terapeuta e cliente somando forças para superar as dificuldades do cliente.

7. Comunicação precisa - o hipnotizador deve estar consciente do que está comunicando ao sujeito, tanto por meio de palavras quanto através de seus comportamentos não-verbais.

8. Utilização dos sintomas - em vez de buscar simplesmente suprimir os sintomas, em alguns casos Erickson sugeria que tais fossem potencializados; tais exageros, por vezes, tornavam-se incômodos para o próprio cliente, que decidia abandonar o comportamento desagradável.

9. Adaptação da hipnoterapia - Erickson trabalhou para que sua abordagem fosse adaptada de acordo com o modo de ser de cada terapeuta, tornando-se conhecida como "terapia estratégica" ou "terapia nãoconvencional".

10. Orientação para o futuro - "Uma das propostas da hipnose e da hipnoterapia é a conscientização do cliente de que ele não tem somente um passado extremamente importante: ele também tem um presente que é mais importante e um futuro ainda mais importante do que o presente e o passado" (in ERICKSON; HERSHMAN; SECTER, 2003, prefácio, p. 13). Nas palavras de Zeig, sua abordagem era "extremamente prática", tendo ele, por objetivo, "ajudar os clientes a assegurarem-se das melhores 
possibilidades para viver efetivamente" (in ERICKSON; HERSHMAN; SECTER, 2003, prefácio, p. 13).

Zeig destaca que a hipnose tradicional era definida operacionalmente como um aumento da suscetibilidade à sugestão; diferentemente, quanto mais Erickson progredia com seus estudos e experiências, passou a enfatizar "a importância da identificação, do acesso, do desenvolvimento e dos recursos internos da pessoa" (in ERICKSON; HERSHMAN; SECTER, 2003, prefácio, p. 13). Se nos primórdios da hipnose, profissionais sugeriam a seus clientes que adormecessem profundamente, com o advento da hipnose ericksoniana raramente esta metáfora vem sendo usada. Em suma, diferentemente de Freud, que apenas utilizou o método em seus estudos, abandonando-o quando não vislumbrou para ele novas aplicações, Erickson se deu conta da importância do estado hipnótico para acelerar os processos de mudanças necessárias a seus clientes, substituindo o transe tradicional por práticas mais sutis, muitas vezes imperceptíveis para o próprio paciente, conforme indicam os dez princípios anteriormente apresentados. 


\subsection{Hipnose: novos usos consagrados a partir de Erickson}

A hipnose ainda encontra restrições junto à comunidade médica bem como no campo da Psicologia. Embora possa ser praticada por qualquer pessoa que se dedique ao estudo e à prática de suas técnicas, a maioria dos médicos prefere procedimentos convencionais como a administração de medicamentos, assim como as correntes mais tradicionais da Psicologia abrem mão de utilizá-la, recorrendo a outras técnicas consagradas.

Segundo Haley (1991) "as preocupações do clínico com a hipnose podem limitar sua compreensão sobre o uso das habilidades hipnóticas". E contextualiza a técnica de acordo com o clima ideológico de cada época:

Quando a terapia era vista como uma experiência religiosa, a hipnose era um ritual místico. Com o desenvolvimento da teoria psicodinâmica, a hipnose passou a ser considerada um fenômeno de transferência. (...) Atualmente, atravessamos um período onde (sic) a hipnose é excessivamente examinada pelos cientistas. Um número considerável de pesquisas estão sendo desenvolvidas para demonstrar que a hipnose não existe, ou melhor, que nada pode ser realizado melhor em transe que num estado de alerta. Numa época científica, a hipnose passa ser definida como uma situação sem importância. Essas pesquisas são muito insignificantes para os clínicos, porque a hipnose pesquisada e a hipnose em terapia são duas ordens de fenômenos diferentes. (...) Se ela pode sobreviver ao período religioso, também sobreviverá ao período científico. O próximo passo será provavelmente redefini-la como fenômeno condicionador, se as terapias condicionantes se desenvolverem mais e se tornarem mais populares. Será necessário aprender a teoria, e o transe será explicado dentro desta moldura (HALEY, 1991, P. 22).

$\mathrm{Na}$ abordagem estratégica de Erickson, a hipnose é encarada como um tipo especial de enquadramento interpessoal, em que o objetivo do operador vai além da modificação do comportamento, da resposta sensorial e do comportamento de outra pessoa. O modelo ericksoniano busca, como objetivos subsidiários, ampliar a gama de experiências do cliente, bem como provê-lo de novos modos de pensar, sentir e se comportar. Como destaca Haley (1991): "Obviamente, esses são também os objetivos da terapia. Tanto o hipnotista quanto o terapeuta procuram, através do relacionamento com a pessoa, introduzir variedade e estender a série de habilidades". Um diferencial na terapia estratégica de Erickson quanto ao uso da hipnose resulta num paradoxo: "o hipnotista dirige a pessoa para que ela 
espontaneamente mude seu comportamento", uma vez que, conforme enfatiza, mediante o transe interacional é possível pesquisar e avaliar os anseios do cliente.

Na visão de Erickson (2003), a hipnose encontrou grande obstáculo por meio da visão divulgada por Charcot de que seria apenas outra forma de manifestação da histeria. Ao contrário, apóia a abordagem de Bernheim e de Liébault de que a sugestão era um fator importante na hipnose. Sobre Freud, comenta:

Freud ouviu falar dos trabalhos de Liébault e Bernheim e em 1890 chegou a Nancy. Ele e Breuer tinham usado a hipnose e estavam interessados em usar essa técnica para ajudar pessoas com distúrbios emocionais. Freud queria desenvolver suas próprias técnicas; estudou com Charcot e Bernheim. Para os seus objetivos achava, entretanto, que as curas eram muito superficiais e consequentemente abandonou o método. A rejeição da hipnose por parte de Freud infelizmente retardou o seu desenvolvimento em pelo menos cinquenta anos (ERICKSON; HERSHMAN; SECTER, 2003, p. 22-23).

Erickson afirma que a hipnose contribuiu para o desenvolvimento dos mais profundos insights freudianos sobre o comportamento humano, influenciando os trabalhos do psicanalista sobre a mente e sobre a recuperação das memórias submersas.

No que se refere a uma suposta fusão da hipnose com a psicanálise, destaca o trabalho do psicanalista alemão Ernst Simmel ${ }^{12}$, que durante a Primeira Guerra Mundial empregou a hipnose para o tratamento das neuroses de guerra, desenvolvendo a técnica que chamou hipnoanálise.

Para Erickson, a fusão da hipnose com a psicanálise foi um dos mais importantes avanços médicos decorrentes da I e da II Guerras Mundiais, despertando a curiosidade de Clark L. Hull, professor de psicologia em Yale e de outros profissionais espalhados pelas Universidades de Long Island, Roosevelt e Tufts, entre outras escolas americanas que mantém o ensino da hipnose em seus currículos.

O crescente interesse pela hipnoterapia ericksoniana, a partir dos anos 2000, pode ser comprovado pela ampliação dos Institutos Milton Erickson por diversos países 41 das 127 unidades foram inauguradas a partir dessa data. No Brasil, 9 das 14 unidades foram instaladas nos anos 2000. O pensamento e as práticas ericksonianas vão, aos poucos, ocupando seu lugar, aguardando a oportunidade de participar formalmente da literatura e da práxis da Psicologia atual.

\footnotetext{
${ }^{12}$ Autor do livro Hypnosis and suggestibility, 1933.
} 


\section{MODELO MILTON: POSTULADOS}

O campo da linguística oferece-nos um vasto recurso para compreender como os humanos processam os complexos segmentos de linguagem a níveis não-conscientes.

RICHARD BANDLER e JOHN GRINDER

Na década de 70, Richard Bandler e John Grinder, professores da Universidade da Califórnia e criadores da "Programação Neurolinguística" $(\mathrm{PNL})^{13}$, uma teoria sobre linguagem e terapia, compilaram e sistematizaram os padrões ericksonianos no Metamodelo da PNL e no Modelo Milton, que aqui serão assumidos como base teórica fundamental para as análises apresentadas nesta tese.

Buscando evidenciar o método oculto sob a aclamada "genialidade" de Erickson no tocante às suas habilidades acerca do emprego de padrões de linguagem como constituintes de um processo terapêutico para a geração de mudanças -, os autores elaboraram o "Modelo Milton", destacando uma série de padrões frequentemente empregados em suas sessões terapêuticas, focados especialmente em comandos verbais e não-verbais.

A finalidade deste capítulo é apresentar as origens do Modelo Milton, os principais conceitos da PNL a ele relacionados bem como as categorias e subcategorias que permitem sua compreensão e aplicação.

\subsection{Modelo Milton: a origem}

O interesse de Bandler e Grinder sobre o terapeuta surgiu durante sua pesquisa sobre PNL, a partir de uma recomendação de Gregory Bateson. O contato inicial entre Bandler e Erickson deu-se de maneira peculiar, conforme o seguinte relato:

$\mathrm{Na}$ década de 70, o dr. Erickson já era muito conhecido entre os profissionais da medicina e era até assunto de vários livros, mas

\footnotetext{
${ }^{13}$ Além do trabalho de Milton Erickson, os autores também basearam seus estudos para a concepção da PNL na Gramática Transformacional de Noam Chomsky, na abordagem de terapia familiar de Virgínia Satir e na gestaltterapia de Frederick (Fritz) Perls.
} 
poucos alunos seus conseguiam reproduzir seus trabalhos ou repetir seus resultados. Dr. Erickson frequentemente era chamado de "curandeiro ferido", visto que muitos colegas seus achavam que seus sofrimentos pessoais eram responsáveis por ele ter se tornado um terapeuta habilidoso e famoso mundialmente.

Quando Richard Bandler ligou pedindo uma entrevista, aconteceu de o dr. Erickson atender, pessoalmente, o telefone. Embora Bandler e Grinder fossem recomendados por Gregory Bateson, Erickson respondeu que era um homem muito ocupado. Bandler reagiu dizendo, "Algumas pessoas, dr. Erickson, sabem como achar tempo", enfatizando bem "dr. Erickson" e as duas últimas palavras. A resposta de Erickson foi, "Venha quando quiser", enfatizando também as duas últimas palavras em especial. Embora, aos olhos do dr. Erickson, a falta de um diploma de psicologia fosse uma desvantagem para Bandler e Grinder, o fato de esses dois jovens talvez serem capazes de descobrir o que tantos outros não haviam percebido o deixou intrigado. Afinal de contas, um deles havia acabado de falar com ele usando uma de suas próprias descobertas de linguagem hipnótica, hoje conhecida como um comando embutido. Ao enfatizar as palavras "dr. Erickson, achar tempo", ele havia criado uma frase separada dentro de uma outra maior que teve o efeito de um comando hipnótico (ANDREAS; FAULKNER, 1995, p. 35, destaques da Autora).

À medida que Bandler e Grinder conheciam de perto o trabalho de Erickson, este foi se tornando uma inspiração para eles, especialmente no que se refere à construção de um modelo para o embasamento da PNL, conforme declaram:

Milton Erickson é aclamado internacionalmente como o astro da prática da hipnose médica. Ele escreveu mais de uma centena de artigos sobre hipnose e tem praticado e falado sobre hipnose desde a década de 20. Mais que qualquer outro ser humano em sua área, ele está habilitado a explorar e demonstrar o vasto potencial que a hipnose tem a oferecer à humanidade. Sua habilidade zomba da mente científica e suas proezas típicas, não obstante, são vistas como milagres ou acusadas de impossibilidades, apesar das experiências apresentadas por ele em primeira mão como inegável realidade, um extraordinário contraste daquilo que a maioria das pessoas acredita ser possível a mente executar. Ademais, alguns de seus alunos aprenderam a exercitar as habilidades que Milton Erickson usa tão facilmente. O comportamento que Milton Erickson demonstra enquanto induz e utiliza os estados hipnóticos de consciência é extremamente complexo. Porém, ele é muito sistemático; é certo, seu comportamento apresenta padrões distintivos (BANDLER; GRINDER, 1975, p.1, tradução da Autora).

O Modelo Milton criado por Bandler e Grinder teve a aprovação do próprio Erickson que, no prefácio do Patterns, volume I, considerou-o uma explicação bem melhor do que a que ele mesmo poderia oferecer sobre a maneira como trabalhava. "Eu sei o 
que faço, mas explicar como faço é demasiado difícil para mim", afirmou (ERICKSON in BANDLER; GRINDER, 1975, prefácio).

O levantamento de tais padrões distintivos presentes nos atendimentos de Erickson tornou-se um desafio para Bandler e Grinder, bem como para outros pesquisadores e terapeutas de visão não-positivista que perpetuam seu trabalho, tais como Haley (1991), Zeig (1983), Rosen (1991) e Rossi (1986), entre outros.

\subsection{Conceitos relevantes da PNL para a compreensão do Modelo Milton}

Outros mecanismos ora apresentados são essenciais para que se possa compreender o Modelo Milton. Segundo Bandler e Grinder (1975), na indução de transes, o terapeuta precisa ser sensível à maneira particular como cada cliente organiza sua experiência - ou seja, é necessário estar atento ao modelo de mundo do cliente, aos seus sistemas representacionais, aos metamodelos por ele construídos e aos processos de modelagem por ele utilizados na construção desse modelo, visando estabelecer para com ele o efetivo espelhamento e o consequente rapport, como a descrição de tais conceitos poderá demonstrar.

\subsubsection{Modelo de mundo, sistemas representacionais e filtros}

O conceito de modelo de mundo, segundo a PNL, refere-se ao simulacro ou "recorte" da realidade conforme concebido pelo cliente. Reflete suas experiências internas, sejam elas elaboradas consciente ou inconscientemente. Identificar o modelo de mundo do cliente permite ao terapeuta compreendê-lo, ampliá-lo empregando o Metamodelo - que será descrito adiante - bem como estreitar seus laços com o cliente, estabelecendo mais facilmente o rapport desejável para o atendimento eficaz.

Os sistemas representacionais constituem os canais de input, por meio dos quais as informações que o mundo oferece são absorvidas. Como afirmam Bandler e Grinder: 
Cada um de nós, como ser humano, dispõe de um número de diferentes modos de representar nossa experiência do mundo. [...] Temos cinco sentidos reconhecidos de fazer contato com o mundo - nós vemos, ouvimos, sentimos, degustamos, cheiramos. Como complemento desses sistemas sensoriais, temos o sistema da linguagem, que usamos para representar nossa experiência. [...] Há três canais de input mais importantes através dos quais, como seres humanos, recebemos informações sobre o mundo à nossa volta visão, audição e cinestesia (sensações corporais) (BANDLER; GRINDER, 1977, p. 33).

Cada indivíduo representa, pois, suas experiências da realidade que lhe é apresentada por meio da linguagem. Bandler e Grinder (1977) destacam que tais representações são submetidas, além desta e dos sentidos, a outros três tipos de filtros, denominados restrições neurológicas, restrições sociais e restrições individuais.

Por ordem das restrições neurológicas, os seres humanos são capazes, por exemplo, de perceber apenas certos tipos de ondas eletromagnéticas (como as ondas sonoras abaixo de 20 ciclos/s ou acima de 20.000 ciclos/s). Nesse sentido, os autores explicam que "nosso sistema nervoso, (...), determinado geneticamente, constitui o primeiro grupo de filtros que distinguem o mundo - o território - de nossas representações do mesmo — o mapa” (BANDLER; GRINDER, 1977).

Por ordem das restrições sociais, de acordo com a própria linguagem de Bandler e Grinder, entende-se que

Uma segunda maneira pela qual nossa experiência do mundo difere do próprio mundo é através do conjunto de restrições ou filtros sociais (os óculos impostos) - referimo-nos a estes como fatores genéticos sociais ${ }^{14}$. Por genética social, referimo-nos a todas as categorias ou filtros aos quais estejamos sujeitos como membros de um sistema social: nossa língua, nossos meios aceitos de percepção, e todas as ficções aprovadas socialmente. Talvez o filtro genético social mais comumente reconhecido seja nosso sistema linguístico (BANDLER; GRINDER, 1977, p. 29).

\footnotetext{
14 Julgou-se conveniente reproduzir a nota de rodapé em que os autores esclarecem: "Adotamos esta terminologia incomum - genética social — para lembrar ao leitor que as restrições sociais no comportamento dos membros da sociedade têm um efeito tão profundo na formação de suas percepções quanto o têm as restrições neurológicas. Também, que as restrições neurológicas, de início determinadas geneticamente, estão sujeitas à contestação e à mudança, exatamente como estão as restrições determinadas, de início, socialmente. Por exemplo, o dramático sucesso que os pesquisadores tiveram em obter controle voluntário sobre partes do assim chamado sistema nervoso involuntário nos humanos (p.ex. onda alfa) como também em outras espécies, mostra que as restrições neurológicas são contestáveis." (Ibid., p. 31).
} 
Por ordem das restrições individuais, os autores as definem como as representações criadas, tomando por base a história pessoal do indivíduo, pois, "assim como cada pessoa tem um conjunto de impressões digitais distintas, assim, também, cada pessoa tem experiências incomuns de crescimento e vida e jamais a história de duas vidas será idêntica” (BANDLER; GRINDER, 1977).

Assim, os sistemas representacionais, submetidos ao sistema da linguagem e em concordância com os filtros citados, reforçam a tese das representações de caráter exclusivamente pessoal de modelo de mundo, variando de indivíduo para indivíduo, bem como justificam a limitação de suas escolhas disponíveis - somente as opções percebidas e "registradas" pela pessoa figurariam como "disponíveis".

No tocante à linguagem, Bandler e Grinder (1977) mencionam que esta "é adequada a preencher sua função como um sistema representativo [destaque da Autora]"; no entanto, "ela própria precisa fornecer um conjunto rico e complexo de expressões para representar nossas experiências possíveis". Este tem sido o desafio da Psicologia nos seus diversos campos e abordagens, ou seja, verificar a complexidade presente nas estruturas subjetivas a partir da representação verbal, linguística, oferecida pelos clientes. A complexidade que envolve a questão da subjetividade valoriza o papel da linguagem no trabalho terapêutico.

Convém observar que, à primeira vista, a PNL parece utilizar a linguagem como instrumento, com o propósito de implantar, por meio da modelagem, significados padronizados, visando à criação de um sentido universal. Todavia, os autores não se referem propriamente ao "uso" instrumental da linguagem, mas baseiam o metamodelo na própria estrutura - ou sistema - da linguagem, de acordo com o modelo da Gramática Gerativo-Transformacional. Resumidamente, os autores explicam que:

A linguagem humana é uma forma do ato de representação do mundo. A Gramática Transformacional é um modelo explícito do processo de representar e comunicar essa representação do mundo. Os mecanismos dentro da Gramática Transformacional e o modo pelo qual representamos nossa experiência são universais a todos os seres humanos. O significado semântico que estes processos representam é existencial, infinitamente rico e variado. O modo pelo qual estes significados existenciais são representados e comunicados é governado por regras. A Gramática Transformacional não modela o sentido existencial, mas o modo pelo qual se forma este conjunto infinito - as próprias regras de representações [destaques da Autora] (BANDLER; GRINDER, 1977, p. 62-62). 
A compreensão desse importante papel da linguagem na construção de sentidos levou Bandler e Grinder a elaborar o conceito de Metamodelo, peça-chave de sua abordagem teórica. As categorias e subcategorias propostas pelos autores a partir do discurso terapêutico ericksoniano, apresentam-se como ferramentas fundamentais para a realização das análises apresentadas nesta tese.

\subsubsection{Metamodelo}

O conceito de metamodelo é apresentado no livro de estréia de Bandler e Grinder, $\underline{A}$ estrutura da magia (BANDLER; GRINDER, 1977), definido como o modelo linguístico "exterior", por meio do qual o indivíduo busca traduzir suas representações interiores que constituem, segundo os autores, seu modelo de mundo.

Todas as realizações da raça humana, positivas ou negativas, envolveram o uso da linguagem. Nós como seres humanos usamos a linguagem de dois modos. Usamo-la, antes de tudo, para representar nossa experiência - chamamos essa atividade de raciocínio, pensamento, fantasia e narrativa. Quando estamos usando a linguagem como um sistema representativo, estamos criando um modelo da nossa experiência. Este modelo de mundo que criamos pelo nosso uso representativo da linguagem está baseado sobre nossas percepções do mundo.

[...] Em segundo lugar, usamos a linguagem para comunicar a outros nosso modelo ou representação do mundo. [...] Quando estamos usando a linguagem para comunicação, estamos apresentando nosso modelo a outros (BANDLER; GRINDER, 1977, p. 42-43).

O metamodelo pode ser mais claramente compreendido a partir da seguinte explicação: "em outras palavras, utilizamos a linguagem para representar nossa experiência - este é um processo particular. Utilizamos, então, a linguagem para representar nossa representação de nossa experiência - um processo social" (BANDLER; GRINDER, 1977, destaques da Autora).

Essa "representação representada" resulta em um "modelo de um modelo", estruturado e reconhecido como tal — daí a denominação metamodelo.

Por estar vinculado ao modelo de mundo particular de cada indivíduo, tendo passado pelo crivo dos três filtros anteriormente apresentados, o metamodelo, ao ser apresentado/comunicado a outrem, em geral é impreciso e "reduzido", 
requerendo uma "ampliação" para que possa ser mais bem compreendido. Para que tais significados subjacentes possam vir à tona, Bandler e Grinder desenvolveram um Metamodelo ${ }^{15}$ baseado nos conceitos de estrutura profunda e estrutura superficial, bem como no processo de derivação da Gramática GerativoTransformacional de Noam Chomsky. A passagem da enunciação formulada em estrutura profunda para estrutura superficial, por meio da derivação, proporciona ao cliente, como resultado final, um metamodelo "mais rico" de sua experiência:

[...] cada frase, dentro do modelo transformacional, é analisada em dois níveis de estrutura, correspondentes a dois tipos coerentes de intuições que os falantes nativos têm: Estrutura Superficial - na qual se dá uma representação de estrutura em árvore ${ }^{16}$ às suas intuições sobre a estrutura coerente - e Estrutura Profunda - na qual se dão suas intuições, sobre o que é uma representação completa das relações semânticas lógicas. Já que o modelo dá duas representações para cada frase (Estrutura Superficial e Estrutura Profunda), os linguistas têm o encargo de expor, explicitamente, como estes dois níveis se ligam. O modo pelo qual eles representam esta ligação é um processo ou derivação que é uma série de transformações (BANDLER; GRINDER, 1977).

A seguir, um exemplo da estrutura de árvores:

\footnotetext{
${ }^{15}$ Para maior clareza, neste estudo emprega-se o termo "Metamodelo", com a inicial maiúscula, referindo-se ao modelo concebido por Bandler e Grinder com suas categorias e subcategorias. Isto para distingui-lo do conceito original de metamodelo, que se refere à descrição apresentada pelo cliente acerca de seu próprio modelo de mundo.

${ }^{16} \mathrm{Na}$ estrutura em árvore, as transformações de uma dada enunciação são representadas esquematicamente, simulando "ramificações".
} 


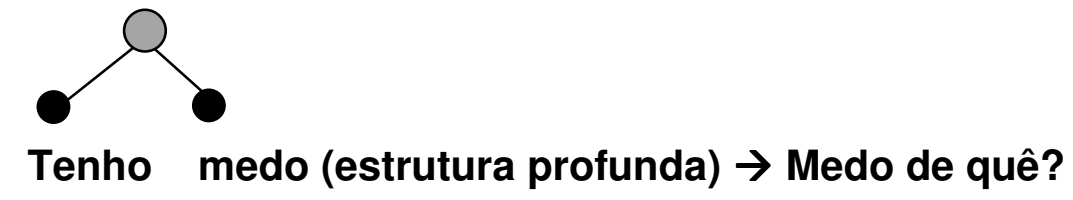

Figura 3 - Exemplo de consitutinte

(Derivação)

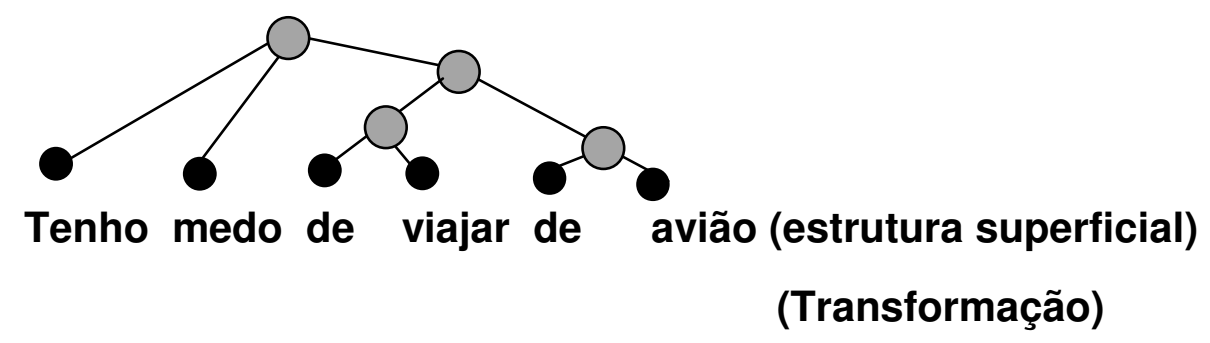

Figura 4 - Exemplo de transformação

A estrutura de árvores da teoria transformacional objetivava obter um conjunto de regras de reescrita que, por meio dos constituintes imediatos $(A=\operatorname{artigo}, N=$ nome/substantivo, $P=$ preposição, $V=$ verbo, etc.), gerassem todos os indicadores sintagmáticos ( $\mathrm{SN}$ = Sintagma Nominal, SV = Sintagma Verbal) capazes de conduzir à sequência terminal (Frase). $O$ esquema buscava evidenciar as regularidades presentes na construção de uma frase gramatical (MEIRELES; RAPOSO, in CHOMSKY, 1975). Os constituintes dos exemplos acima ("Tenho medo" $V+\mathrm{N}=\mathrm{SV}$ + "de viajar" $P+V=S V=$ "de avião" $P+N=S N$ ), aqui representados pelo símbolo $O$, mostram como os constituintes vão se juntando de maneira a conferir um sentido mais completo à frase final.

Bandler e Grinder observam que, analogamente, quando em terapia, os clientes, apresentam suas questões a partir da estrutura profunda. Sendo esta mais afeita ao inconsciente, muitos significados relevantes são ocultados pelo cliente e/ou subentendidos por quem se dedica à escuta. Torna-se necessário, pois, transformar esses significados de maneira que possam trazer dados mais precisos "à superfície". Tais transformações são obtidas por meio de perguntas formuladas ao cliente (Ex.: "E o que mais isto pode significar?"). "O processo de derivação consiste em uma série de transformações sucessivas, que ligam a estrutura profunda à estrutura superficial" (BANDLER; GRINDER, 1977). Tal como ocorre, analogamente, com os conteúdos latente e manifesto da abordagem freudiana. Em resumo: 
O metamodelo foi concebido para ensinar o ouvinte a ouvir e reagir à forma da comunicação de quem fala. O conteúdo pode variar infinitamente, mas a forma da informação dada propicia ao ouvinte a oportunidade de reagir de modo a obter o significado mais completo da comunicação. Com o metamodelo é possível perceber rapidamente a riqueza e os limites da informação dada, bem como os processos humanos de modelagem usados por quem fala. Ouvir e reagir segundo as definições propostas pelo metamodelo faz de qualquer comunicação a mais compreensível e profícua (CAMERONBANDLER $^{17}, 1991$, p.223).

Por tornar possível a identificação dos limites do modelo de mundo do emissor/cliente - consequentemente, sua representação para seus interlocutores, ou seja, da maneira como "seu mundo" é comunicado aos demais -, o uso do Metamodelo transforma-o numa ferramenta eficaz nos atendimentos da terapia estratégica, uma vez que permite extrair informações mais detalhadas e precisas a partir dos enunciados propostos pelo emissor/cliente.

Consequentemente, como corolário, "o Metamodelo fornece maneiras de recuperar informações específicas que estejam omitidas em alguma sentença” (BANDLER; GRINDER, 1984, p. 277). A partir de certos padrões de linguagem formulados em estrutura profunda recorrentes na linguagem comum do cotidiano, os autores identificaram as categorias e subcategorias por meio das quais criaram o Metamodelo da PNL.

Percebe-se, pelo desenvolvimento da abordagem da PNL, sua diferença epistemológica com o condutivismo, que recupera sentidos pelo encadeamento de respostas, enquanto o Metamodelo, diferentemente, os recupera pelo uso dessa estrutura sobre a realidade observável.

\subsubsection{Metamodelo: categorias e subcategorias}

Para aplicar o Metamodelo, Bandler e Grinder elaboraram três categorias - com suas respectivas subcategorias - que constituem a instrumentalidade para 0 terapeuta. São elas:

\footnotetext{
${ }^{17}$ Leslie Cameron-Bandler é apontada como co-criadora da PNL.
} 

A. Coleta de informações
B. Má-formação semântica
C. Limites do modelo do emissor

Em cada uma delas é possível identificar reduções de sentido causadas pela formulação de enunciados em estrutura profunda por parte do cliente. Quando submetidas ao processo de derivação, passando para a estrutura superficial, tais reduções ganham novos e esclarecedores significados que permitem a expansão do modelo de mundo do cliente, apontando novas direções que podem ser seguidas para acelerar as mudanças necessárias à adoção de novos comportamentos.

\section{A. Coleta de informações}

A coleta de informações visa a reconectar a linguagem do emissor à sua experiência por meio de perguntas cujas respostas forneçam descrições mais completas e precisas dessa experiência. Os autores apontam quatro subcategorias relativas à coleta de informações:

1. Nominalizações - Esta categoria trata de um processo de reificação que facilita a comunicação. "Palavras (processuais) que entram no lugar de um substantivo na sentença, mas não são tangíveis - não podem ser tocadas, sentidas nem ouvidas" (BANDLER; GRINDER, 1984, p. 278); qualquer substantivo que, metaforicamente, "não possa ser colocado num carrinho de mão". Palavras processuais, segundo os autores, são aquelas em que, figurativamente, um processo é transformado numa "coisa" ou evento como, por exemplo, aprendizagem (resultado do processo de aprender), hipnose (resultado do processo de hipnotizar), amor (resultado do processo de amar), fracasso (resultado do processo de fracassar).

Por serem inespecíficas, as nominalizações permitem que cada interlocutor atribua a elas o significado que melhor the convier para compor o sentido da frase. Ao empregar nominalizações, o emissor busca a aprovação consensual da plateia, gerando uma concordância automática - hipnótica sem correr o risco de dizer algo que contrarie a experiência interna de cada 
indivíduo nem gerar conflitos. Ex.: "Sei que cada um de vocês já enfrentou uma certa gama de dificuldades em sua vida, problemas que pareciam não ter solução..." Sem especificar o tipo de dificuldade, problema e solução a que se refere, o emissor induz qualquer interlocutor da plateia a concordar inicialmente com a afirmação posta, tomando-a por verdadeira a partir de suas experiências individuais.

A reversão das nominalizações ajuda o cliente a ver que aquilo que considerou um evento acima e além do seu controle é, de fato, um processo contínuo que pode ser mudado (CAMERON-BANDLER, 1991).

Para permitir que o cliente perceba a possibilidade de mudança, ampliando desta forma seu modelo de mundo, é preciso aplicar o processo de derivação, dirigindo a ele uma pergunta que empregue o verbo que deu origem à nominalização, revertendo-a, então, à sua condição de processo. Exs.:

- Não consigo reconhecimento por parte da chefia.

"Como você gostaria de ser reconhecido?"; ou "Como você saberia que é reconhecido?".

- Preciso de ajuda.

"Como você quer ser ajudado?".

2. Verbos não-específicos - Esta categoria trata da busca precisa da ação. Para Bandler e Grinder, nenhum verbo é completamente específico, descrevendo, na maioria das vezes, uma ação desvinculada de seu resultado e generalizada (embora alguns pareçam mais específicos que outros - beijar, por exemplo, é mais específico que acariciar). Com isso, o interlocutor também é forçado a suprir a frase de significados para a apreensão do sentido. Para aprofundar o significado e chegar ao resultado da ação, os autores sugerem a indagação "como, especificamente...?". Exs.:

- Pedro me rejeitou.

"Como, especificamente, ele a rejeitou?"; ou "Como ele fez isso?". 
- A Diretoria me persegue.

"Como, especificamente, a Diretoria faz isso?".

3. Índice referencial não-específico - Esta categoria pede a especificidade do sujeito. Semelhante à subcategoria anterior, aqui o sujeito da oração é inespecífico, em geral representado por pronomes indefinidos. Para atribuir responsabilidades ou definir foco sobre a ação engendrada, cabe perguntar "quem / o que, especificamente...?". Exs.:

- Ninguém me ama.

"Quem, especificamente, não o ama?"

- Nada dá certo em minha vida.

"O que, especificamente, não dá certo em sua vida?"

- As pessoas adoram falar mal da vida alheia.

"Quais pessoas, especificamente, falam mal da vida alheia?"

- A diretoria não aprovará o projeto.

"Quem da diretoria, especificamente, vetará o projeto?"

4. Omissão - Esta categoria pede um complemento. Neste caso, uma oração subordinada fundamental à construção do sentido é completamente omitida deixando no ar certa expectativa, buscando, novamente, que o interlocutor a subentenda de acordo com sua própria experiência, mediante a relevância do significado frente ao seu modelo de mundo. A fim de buscar um significado comum a ambos, cliente e terapeuta, as perguntas-chave são: "(d)o quê?" ou "(de) quem?". Exs.:

- Sei que você está curioso.

"Curioso sobre o quê?"

- Tenho muito medo.

"De quem? ou "Do quê?"

Estas subcategorias mostram táticas empregadas pelo terapeuta para decodificar o discurso do cliente, tornando-o mais compreensível para ambos. 


\section{B. Má-formação semântica}

Além de aprofundar o sentido dos enunciados oferecidos pelos clientes, é vital, para o trabalho do terapeuta, que este possa se valer de técnicas de interpretação como as que se apresentam nesta categoria.

A má-formação semântica (também traduzida como "formação semântica deficiente") reduz a possibilidade de escolhas do indivíduo, à medida que atribui um sentido aparentemente único e inequívoco à frase. Apresenta as seguintes subcategorias:

1. Modelo causal ou vinculação - Esta categoria trata da aplicação de palavras que implicam, artificialmente, numa relação de causa e efeito "entre algo que está ocorrendo e algo que o comunicador quer que ocorra". "A formação semântica de causa e efeito envolve a crença de que uma ação por parte de uma pessoa pode levar outra pessoa a agir de um modo particular ou a experimentar uma determinada emoção ou um determinado estado subjetivo. Devido a essa crença, a pessoa que está reagindo às experiências não tem escolha. Desafiar essa crença permite à pessoa examinar se a conexão causal é de fato verdadeira", destaca Cameron-Bandler (1991, p. 227).

Bandler e Grinder destacam três tipos de vinculação, aos quais atribuem graus variados de força, em ordem crescente a partir dos exemplos a seguir:

a. O emprego de conjunções aditivas para conectar fenômenos não relacionados. Exs.:

- Você está ouvindo a minha voz e pode começar a relaxar.

- Você inspira, expira e sua mente se abre para novas experiências.

- Você tem curso superior e pode ser facilmente hipnotizado.

b. O emprego de preposições e conjunções que indiquem relações temporais para conectar afirmações. Exs.:

- É fácil sentir-se confiante quando estou por perto.

- Você relaxa mais intensamente enquanto mexe seu pescoço suavemente para frente e para trás. 
c. $\mathrm{O}$ emprego de verbos que, declaradamente, implicam causalidade. Exs.:

- Fechar os olhos e pensar na cor verde causa uma sensação relaxante.

- Comprar um vestido novo faz com que você se sinta feliz.

Cameron-Bandler destaca também, nesta subcategoria, a relevância do uso de verbos reflexivos de teor pejorativo (aborrecer-se, incomodar-se, frustrarse, etc.) no tocante às relações de causa e efeito. Exs.: Você me aborrece (me irrita, me frustra, me incomoda, etc.). Para a ampliação do modelo de mundo ante tais afirmações, a autora recomenda buscar novas alternativas de reação assim que a verdadeira causa da situação desagradável for identificada ("O que essa pessoa faz que me aborrece?" Ou: "Como essa pessoa faz para que eu me sinta irritada?"). Um novo e positivo comportamento pode ser gerado a partir da identificação do processo causador do aborrecimento ou da irritação.

2. Leitura da mente - Através deste instrumento, o emissor age como se soubesse exatamente como a outra pessoa sente/pensa mediante uma dada ação ou experiência; cria, assim, uma espécie de cumplicidade para com o interlocutor, tornando-se confiável. No entanto, se o comentário parecer presunçoso demais, contrariando a experiência do interlocutor, o elo se desfaz, provocando um efeito contrário, de separação e afastamento. Exs.:

- Sei quanta desconfiança existe em relação à PNL.

- Você deve estar se perguntando: quanto tempo falta para acabar a aula?

3. Performativo ausente (ou índice referencial, segundo Cameron-Bandler) Esta subcategoria trata das reações generalizadas não atribuídas a um sujeito específico. Afirmações que encerram algum tipo de avaliação ou julgamento com sujeito indefinido; encerram uma generalização sobre o mundo, o senso comum, em vez de expressar alguma experiência própria do modelo de mundo do emissor, induzindo os interlocutores a compartilharem as regras e opiniões sugeridas pelo emissor. Exs.: 
- É bom fazer, pelo menos, cinco pequenas refeições ao dia.

- É errado brincar com os sentimentos dos outros.

- Este é o melhor jeito (ou o jeito mais rápido) de emagrecer. Para estes casos, Cameron-Bandler sugere perguntar: "É bom para quem?"; "Errado em relação a quê?"; "Melhor para quem?"

O terapeuta é um profissional que dispõe de ampla diversidade de caminhos para ajudar o cliente a interpretar a si mesmo e o conteúdo gerado pelos diálogos que se apresentam durante a sessão terapêutica. A partir da desconstrução da máformação semântica apresentada pelo cliente, a gama de escolhas que the são oferecidas é ampliada consideravelmente.

\section{Limites do modelo do emissor}

Esta subcategoria trata de questionar o valor da informação dada, recategorizando a escala de valores por meio de generalizações tanto abrangentes quanto imprecisas, através das quais, o locutor busca gerar consenso com os interlocutores apoiando-se novamente no senso comum; para isso, vale-se das seguintes subcategorias:

1. Quantificadores universais - Indicadores de uma supergeneralização includente - todos, tudo, todo mundo, sempre - ou excludente - nenhum, nada, ninguém, nunca. Exs.:

- Isso sempre me acontece (afirma alguém, depois de entornar a xícara de cafezinho). "Sempre?? Todas as vezes, sem exceção??"

- Jamais conseguirei emagrecer. "Quantas vezes já tentou? Que métodos utilizou?"

- Todos os homens são iguais (afirma a solteira desiludida, em tom pejorativo, referindo-se aos solteiros que não querem compromisso de casamento). "Quantos homens você conhece? Conhece algum que já foi solteiro e, de repente, decidiu se casar?".

- Nenhum homem presta (afirma a mesma solteira desiludida). "Nenhum?? Seu pai e seu irmão são homens? Eles também não prestam?" 
2. Operadores modais - Nesta subcategoria, os valores são revistos a partir do jogo de forças que representa o poder. Sejam eles de necessidade ("tenho de", "preciso", "é necessário", "devo") ou de impossibilidade ("não posso", "é impossível", "não consigo"), indicam ausência de opção, consolidando crenças limitantes. Exs.:

- Não posso ficar até mais tarde hoje. ("Senão perderei a carona" comentário interno).

$\mathrm{Na}$ verdade, a pessoa pode, mas opta pela carona. Usando a expressão "não posso", no entanto, ameniza a contrariedade experimentada pelo chefe que contava com sua colaboração, pois o impedimento tem efeito de real, intransponível.

- Tenho de entregar o relatório até dez horas.

Talvez o prazo pudesse ser negociado e a entrega postergada por mais uma hora - quem sabe por um dia. No entanto, ao receber a instrução do emissor/chefe, o interlocutor/subalterno, embora tivesse uma série de outras atividades importantes a desempenhar, sequer argumentou sobre a possibilidade de postergar a entrega e amargou a angústia do prazo exíguo.

- É impossível trabalhar após passar a noite inteira acordado.

Realmente é desagradável trabalhar sem dormir o tempo suficiente; a produtividade pode até cair, mas não é "impossível" trabalhar...

Através do que Bandler e Grinder categorizaram neste terceiro critério, o terapeuta tem à sua disposição mais uma fonte de poder por meio do reconhecimento - ou não - da ação apresentada pelo cliente. Integrando as três categorias pode-se perceber a amplitude dos recursos disponibilizados ao terapeuta pela PNL.

No Modelo Milton, tais estratégias discursivas desenvolvidas para o Metamodelo estão disponíveis para o terapeuta para serem empregadas "ao contrário", de forma a tornar o discurso do terapeuta "artisticamente vago". Tal estratégia visa a reduzir o sentido dos enunciados, buscando trabalhar, tanto quanto possível, apenas em estrutura profunda, evitando o processo de derivação. O Modelo Milton será explicado e exemplificado no tópico 3.3. 


\subsubsection{Espelhamento e rapport}

Bandler e Grinder (1982) aprofundam a explicação do sucesso dos atendimentos terapêuticos de Erickson recorrendo a dois conceitos - espelhamento e rapport que revelam mais nuances da terapia estratégica em ação. Os autores entendem espelhamento (pacing) como o acompanhamento do comportamento do cliente, tanto verbal quanto não-verbal; essa ação terapêutica permite que o cliente possa se ver no terapeuta como se mirasse um espelho.

Este recurso abre caminho para o estabelecimento do rapport, que é uma relação em processo entre o cliente e o terapeuta para facilitar a comunicação entre ambos visando a possíveis mudanças de comportamento. O rapport estabelece um sistema de trocas simbólicas e define os papeis específicos a serem vivenciados nessa relação terapeuta/cliente. Segundo os autores:

O espelhamento é a base do que a maioria das pessoas denominam de relacionamento (rapport), havendo tantas dimensões dele quantas forem as que sua experiência sensorial conseguir discriminar. Podese espelhar os predicados e a sintaxe de outra pessoa, sua postura corporal, sua respiração, sua tonalidade de voz e o andamento em que fala, sua expressão facial, as piscadas de seus olhos, etc. (BANDLER; GRINDER,1982, p. 95).

No espelhamento (pacing) verbal, os autores destacam duas categorias de descrição fundamentais. A primeira categoria compreende as descrições fundadas no sensorial (observáveis) e depende, fundamentalmente, da acuidade do terapeuta em distinguir certos padrões ao observar e ouvir o que o cliente diz e como isso se incorpora ao seu comportamento. Por exemplo, o terapeuta é capaz de observar o ritmo respiratório do cliente e marcar seu compasso através da silabação de certas palavras ("Você inspira su-a-ve-men-te... e ex-pi-ra...");

\section{A segunda categoria compreende as descrições fundadas no não-sensorial} (não-observáveis) e permite oferecer ao cliente procedimentos gerais que serão utilizados por ele de maneira idiossincrática; portanto, as interpretações que ele fizer terão um significado pessoal. Mesmo que o terapeuta não alcance esse significado, é capaz de conectá-lo às descrições observáveis para alcançar seus propósitos de ajudá-lo na busca de alternativas (enriquecimento de seu modelo de mundo). 
O terapeuta hábil pode transitar de uma categoria a outra, explorando os recursos que cada uma lhe oferece para conduzir o cliente na direção que melhor o ajude a alcançar o estado de relaxamento desejável. Pode, por exemplo, observar a fisionomia do cliente relaxar - a expressão das pálpebras e das linhas da testa vão suavizando (mas ele não sabe, ao certo, o que o cliente está realmente pensando/sentindo) -; a partir de então, pode criar a conexão entre o que é observável (sensorial) com o que supõe ser a sensação do cliente (não-observável) usando um conectivo: "Você ins-pi-ra... ex-pi-ra... e sente uma agradável sensação de conforto e serenidade...").

Tal como ocorre na explicação do espelhamento (pacing), Bandler e Grinder destacam também dois tipos de espelhamento não-verbal: o direto, como, por exemplo, quando o terapeuta passa a respirar no mesmo ritmo e com a mesma profundidade que o cliente. O segundo, é chamado espelhamento cruzado (crossover mirroring), podendo se dar dentro do mesmo canal ou em canais diferentes. No primeiro caso, o terapeuta pode, por exemplo, movimentar suavemente sua mão acompanhando o ritmo da respiração do cliente, evidenciada pelo movimento de subida e de descida do seu peito (mesmo canal, movimento corporal). No segundo caso, o terapeuta pode pausar sua fala de acordo com o ritmo respiratório do paciente (canal fonológico-auditivo em consonância com o sensório-corporal). Assim, o terapeuta é capaz, à medida que conhece os processos da PNL anteriormente apresentados, de se valer desses recursos para "espelhar" (pace) e "conduzir" (lead) o comportamento do cliente. Para Bandler e Grinder (1982), o espelhamento não-verbal constitui um mecanismo inconsciente poderoso que todo ser humano usa para se comunicar efetivamente.

Depois de explicar os conceitos de espelhamento e rapport, Bandler e Grinder analisam táticas que facilitam a elaboração dessas ações como, por exemplo, os sistemas representacionais do cliente e sua valia para estabelecer espelhamento. $O$ modelador experiente observa a sequência dos canais de input mais utilizados para a concepção do modelo de mundo do cliente. Assim, é capaz de perceber se o cliente apresenta traços evidentemente visuais ao relatar seu metamodelo, valendose, por exemplo, de imagens e/ou, palavras como "imagine", "vejo", "colorido", "belo", além de apresentar o olhar perdido ao longe, ter a fala mais rápida - na tentativa de 
acompanhar os detalhes das cenas que descreve -, consequentemente, ter a respiração mais curta e torácica.

Já um cliente que elabora seu modelo de mundo dando preferência a estímulos auditivos - tomando por base, por exemplo, coisas sobre as quais "ouviu falar" apresentará seu metamodelo com voz pausada, em tom agradável, com gestos contidos, respiração suave e uniforme, olhar baixo, como quem estabelece previamente um diálogo interior.

Já um tipo mais cinestésico apresentará uma postura mais relaxada, talvez projetando seu corpo na direção do terapeuta, como quem quer alcançá-lo ou tocálo, uma vez que privilegia o conforto físico e as sensações ligadas a tato, paladar e olfato. Referindo-se ao próprio metamodelo, empregará palavras como "duro", "estressado", "pesado", "suave", "gostoso", "pressionar" e outras que denotem sensações físicas. Em geral, nesses casos, a voz é baixa, ressonante, acompanhando uma respiração profunda.

Uma vez explicados os conceitos de espelhamento e rapport e sua importância na relação cliente/terapeuta, fica mais fácil compreender por que Erickson despertou o interesse de tantos estudiosos à procura de evidenciar os padrões que tornaram sua terapia estratégica um método de sucesso.

\subsubsection{Modelagem}

Ainda há um conceito requerido para a compreensão do Metamodelo:, o conceito de "modelagem" (modeling), uma espécie de técnica descritiva "passo a passo" sobre como o terapeuta faz/realiza mudanças a partir de modelos que tivessem seu knowhow desvelado. Segundo afirmam Bandler e Grinder:

Denominamo-nos [os terapeutas da PNL] modeladores. O que fazemos essencialmente é prestar muito pouca atenção ao que dizem as pessoas e uma enorme atenção ao que fazem. A seguir, construímos para nós um modelo do que as pessoas fazem. (...) Não temos a menor ideia do que seja a natureza "real" das coisas e também não estamos especialmente interessados no que seja "verdadeiro". A função da modelagem é atingir descrições que sejam úteis. (BANDLER; GRINDER, 1982, p. 21, comentário da Autora). 
Apoiando-se na analogia cérebro/máquina, Bandler sintetiza o processo de modelagem afirmando tratar-se de uma representação da maneira como alguém realiza algo, de forma a poder gerar e perpetuar um modelo que possa ser reproduzido:

A modelagem coloca o computador para fazer o mesmo que um ser humano. Como conseguir que uma máquina ligue e desligue as luzes na hora certa e resolva um problema de matemática? Os seres humanos fazem isto. Alguns sempre bem, outros de vez em quando e outros ainda nunca conseguem fazê-lo bem. O modelador tenta obter a melhor representação da maneira como uma pessoa desempenha uma tarefa e torna-a disponível para a máquina (BANDLER, 1987, p. 25).

Em suma, para a PNL, "modelar" é criar modelos reproduzíveis a partir da observação de comportamentos que ofereçam resultados "desejáveis", acompanhando, passo a passo, como tais comportamentos são gerados.

Erickson foi minuciosamente "modelado" por Bandler e Grinder. A dupla de estudiosos acompanhou-o em vários atendimentos e workshops, observando a linguagem do terapeuta em relação às categorias e subcategorias do Metamodelo, seu espelhamento verbal e não-verbal diante dos clientes e como tudo isso se traduzia em rapport, de forma a estabelecer um forte elo de confiança entre ambos. A partir do uso incomum dessas capacidades, Erickson era capaz de criar um modelo preciso de seus pacientes, para facilmente entrar em rapport com eles, conduzindo-os, na sequência, às mudanças de comportamento almejadas.

Estar atento ao modelo de mundo do cliente, buscando criar para ele um metamodelo útil e exequível, em consonância com suas próprias experiências, são características marcantes na terapia estratégica de Erickson, desveladas pela modelagem empreendida por Bandler e Grinder. Suas extraordinárias habilidades foram observadas, modeladas e categorizadas por Bandler e Grinder, que conceberam uma síntese do trabalho de Erickson denominada Modelo Milton, conforme será vista a partir dos tópicos seguintes. 


\subsection{Modelo Milton na prática}

Nesta seção e até o final deste capítulo, será apresentado o Modelo Milton, tal como foi sintetizado por Bandler e Grinder, que servirá como base para a análise do discurso terapêutico de Erickson nos casos selecionados

Como visto, Erickson era capaz de utilizar os canais de output do próprio cliente como um mecanismo de feedback de sua experiência subjetiva, criando uma semelhança de seu próprio comportamento com o do cliente, tanto no nível consciente/observável quanto no nível inconsciente/não-observável. Embora ele próprio não tivesse uma descrição clara sobre como se estabelecia o rapport com seu cliente, seus colaboradores e seguidores foram capazes de apontar e organizar uma série de padrões presentes em seus atendimentos, que serviram como base para o Modelo Milton.

Ao levantamento de Bandler e Grinder publicado em 1975 (BANDLER; GRINDER, 1975) seguiram-se os "padrões adicionais" apontados pelos autores em 1981, os levantados por Haley em 1986 e por Zeig em 1989 (in ERICKSON; HERSHMAN; SECTER, 2003, prefácio), apenas para mencionar os principais estudiosos dedicados ao tema.

Para melhor compreensão, tais padrões são apresentados a seguir.

\subsubsection{Os padrões ericksonianos de linguagem}

Zeig (1983, s/d) e Haley (1991) destacam, em seus estudos, alguns padrões linguísticos presentes na abordagem terapêutica ericksoniana que caracterizariam, potencialmente, um método; os autores atribuem parte do sucesso obtido por Erickson no tratamento de seus clientes ao emprego de padrões tais como:

- $\quad$ utilização do contexto, de indicações (denotações) e de injunções (conotações) a fim de promover mudanças;

- uso da comunicação indireta (discurso indireto);

- emprego de anedotas, metáforas e analogias na construção de novos significados a partir dos conteúdos oferecidos pelo paciente; 
- utilização de associações e confrontações indiretas;

- elaboração de predições a seus pacientes (este padrão, bem como os anteriores, foram apontados por Zeig);

- encorajamento da resistência e de uma possível recaída por parte do paciente, a fim de criar empatia;

- provocação de alguma frustração, a fim de obter uma resposta (reação) do paciente;

- uso do espaço e de posições;

- ênfase nos aspectos positivos levantados pelo paciente;

- efeito de continuidade, unindo significados diferenciados (através de conectores argumentativos, em especial conjunções aditivas no lugar de adversativas);

- utilização dos desvios comportamentais do paciente a fim de provocar um colapso em seu sistema de significações, visando consequente reorganização;

- estímulo à "desaprendizagem" de comportamentos que resultam nocivos ao paciente;

- omissão de interpretações sobre as supostas causas dos comportamentos nocivos cultivados pelo paciente (padrões apontados por Haley).

A estes padrões de linguagem, somam-se outros, apresentados por Bandler e Grinder sob o nome "padrões adicionais (ao Metamodelo) do Modelo Milton", detalhados a seguir.

\subsubsection{Modelo Milton: inversão das categorias do Metamodelo}

Segundo Bandler e Grinder, o Modelo Milton atua no sentido inverso do Metamodelo da PNL. Por exemplo, no Metamodelo, através das nominalizações, busca-se esmiuçar o não-dito, passando-se da estrutura profunda para a estrutura superficial. O Modelo Milton evita esse recurso, conforme dito por seus elaboradores:

Frequentemente, o Modelo Milton tem sido chamado o inverso do Metamodelo. (...) O Metamodelo é um conjunto de padrões linguísticos que pode ser usado para especificar mais completamente a experiência. O Modelo Milton, ao contrário, fornece ao usuário 
maneiras de ser 'artisticamente vago'. Ser artisticamente vago permite ao comunicador fazer colocações que soem específicas e que, todavia, sejam suficientemente gerais para espelharem adequadamente a experiência do ouvinte, independente do que ela seja. O Metamodelo fornece maneiras de recuperar informações específicas que estejam omitidas em alguma sentença; o Modelo Milton fornece maneiras de construir sentenças nas quais praticamente todas as informações específicas estejam omitidas. Isto requer do ouvinte que ele preencha as lacunas com sua própria experiência interna (BANDLER; GRINDER, 1984, p. 277-278).

Como se pode constatar nesta citação, todas as categorias e subcatregorias do Matamodelo devem ser exploradas na direção inversa no Modelo Milton. Por exemplo: no Metamodelo, as nominalizações são debeladas através de perguntas que busquem clarificar seu significado ("Preciso de ajuda" - De que maneira você quer ser ajudado?) revertendo, pois, a nominalização em processo, a fim de ampliar o modelo de mundo do cliente. Já no Modelo Erickson, o terapeuta "nomeia" as descrições fundadas no não-observável de forma a provocar no cliente um determinado estado ou comportamento de caráter reducionista ("À medida que você senta nesta poltrona e relaxa, estará apto a receber a minha ajuda'). Ao relacionar um dado estado de conforto físico à ajuda desejada pelo cliente, o terapeuta permite que o cliente preencha as lacunas que se abrem entre o relaxamento alcançado e a ajuda almejada no tratamento; este é um dos exemplos do que Bandler e Grinder chamam de "ser artisticamente vago".

\subsubsection{Modelo Milton: novas categorias}

Em suma, o Modelo Milton oferece estratégias ao terapeuta para que este construa um discurso, durante o atendimento, de forma a conduzir o cliente na direção da auto-regulagem necessária para alcançar as mudanças desejáveis.

Além da inversão do Metamodelo analisada no tópico anterior, o Modelo Milton agrega outras três categorias compostas por "importantes padrões linguísticos", de aplicação específica: 


\section{Pressuposições \\ II. Padrões de eliciação indireta \\ III. Padrões na metáfora}

\section{Pressuposições}

Bandler e Grinder apresentam as pressuposições como poderosos padrões linguísticos que podem ser usados por um comunicador que não queira admitir questionamentos a respeito de um enunciado. "O modo de determinar aquilo que está pressuposto e fechado a questionamento numa sentença é negando a sentença e encontrando aquilo que ainda resta de verdadeiro. $O$ tipo mais simples de pressuposição é a existência”, (BANDLER; GRINDER, 1984, p. 281). Baseandonos no exemplo por eles apresentado, se alguém afirma que "João comeu o bolo", pressupõe-se a existência de João e do bolo; ao aplicarmos a negativa ("João não comeu o bolo"), tanto João quanto o bolo continuam existindo.

Em Patterns I, os autores apresentam um detalhado apêndice no qual relacionam indicativos sintáticos para a identificação de pressuposições na língua inglesa "natural" (ou seja, baseada no modelo gerativo-transformacional). Bandler e Grinder evidenciam duas subcategorias de pressuposições: as simples e as complexas. Dentre as pressuposições simples - aquelas nas quais a existência de uma entidade é necessária para que a frase adquira sentido - destacam:

a. Nomes próprios: "Paulo saiu cedo para trabalhar" (pressupõe a existência de alguém chamado Paulo).

b. Pronomes pessoais (ele, ela, o, a, etc.): "Eu o vi sair" (pressupõe a existência de alguém do sexo masculino).

c. Descrições de definição: "Eu gosto do rapaz de cabelos longos" (pressupõe a existência de um rapaz de cabelos longos em detrimento de outros, provavelmente com cabelos curtos).

d. Nomes genéricos que representem toda uma classe: "Os metalúrgicos entraram em greve" (pressupõe a existência da classe dos metalúrgicos). 
e. Alguns tipos de quantificadores como todos, cada, alguns, uns poucos, uns: "Bastam alguns adolescentes para a festa tornar-se uma bagunça" (pressupõe a existência de adolescentes).

Embora as pressuposições simples não contribuam significativamente para a análise de casos baseada no Modelo Erickson que integrará esta tese, optou-se por apresentá-las somente em contraposição à subcategoria das pressuposições complexas, aquelas em que, segundo Bandler e Grinder (1975, p. 258), "mais do que a simples existência de um elemento é pressuposta". Tais pressuposições complexas abrangem:

1. Pronomes relativos: complexos substantivos argumentativos com um substantivo seguido de um enunciado iniciado por que, o qual, quem ou aquele: "Cada um os homens que Ihe dirigiram a palavra foram insultados" (pressupõe que alguns homens tenham dirigido a palavra a alguém);

2. Cláusulas (sentenças) temporais subordinadas - emprego de advérbios e expressões temporais como antes, depois, durante, enquanto, quando, uma vez que, à medida que. Ex.: "Você pode relaxar tranquilamente na poltrona enquanto entra em transe" permite pressupor que a pessoa alcançará o transe hipnótico; ou "Você ficará bem depois que concluir o tratamento" pressupõe que a pessoa concluirá o tratamento;

3. Frases de efeito (cleft sentences): originalmente, cleft sentences são frases que "interrompem" a formação sintática clássica (ex.: sujeito + predicado + objeto), dando ênfase a uma parte da sentença, empregando, por vezes, um complemento. Ex.: A frase "Eu gosto de ir ao cinema" no formato "cleft sentence" poderia ser formulada das seguintes maneiras: "Cinema, isto sim, eu gosto!"; ou "Cinema: ah, como eu gosto!". O exemplo original de Bandler e Grinder destaca a presença do verbo impessoal haver + substantivo como em "Houve uma pressão extra que estilhaçou a janela" (pressupõe que algo estilhaçou a janela) 
4. Pseudo-frases de efeito, (pseudo-cleft sentences) identificadas através da fórmula $\mathbf{O}$ que [enunciado] é [enunciado]: "O que João espera conseguir é um emprego melhor" (pressupõe que João espera conseguir algo).

5. Frases assinaladas (ou acentuadas - stressed sentences) através de grafia diferenciada (linguagem escrita) ou tom de voz ou velocidade/intensidade da fala: "Se ALGUÉM está esperando por aumento, pode esquecer 0 assunto" (pressupõe alguém, especificamente - com uma expectativa - que não será contemplada.

6. Adjetivos complexos como novo, velho, anterior, posterior, presente, prévio: "Quando Matilde vir meu novo carro, morrerá de inveja" (pressupõe a existência de um carro anterior).

7. Ordenação - uso de numerais ordinais ou expressões equivalentes para ordenar práticas ou ações (geralmente recomendadas pelo terapeuta a fim de alcançar um resultado). Ex.: "Vou lhe explicar como ocorre o transe hipnótico: primeiramente sua respiração entra num ritmo pausado e confortável; em segundo lugar, seu corpo relaxa e você é capaz de desligar-se do mundo"; as duas afirmações, assim ordenadas, conferem assertividade ao hipnotista, fazendo o cliente pressupor que o transe acontece dessa forma, evitando confrontos e questionamentos, pois a ordenação organiza os enunciados de acordo com um modelo lógico. Ou em "Se você desvendar também o terceiro mistério do jogo, eu lhe dou o prêmio" (pressupõe que a pessoa já tenha desvendado dois mistérios anteriores).

8. Uso de comparativos como maior, melhor, mais esperto, menos inteligente: "Paulo é melhor nadador que Joaquim" pressupõe que Joaquim também é nadador; "Este quadro é maior que aquele" pressupõe a existência de um quadro menor.

9. Uso de comparativos através das fórmulas tão/tanto quanto ou assim como: "Se Paulo for tão inteligente quanto Joaquim, passará no vestibular" (pressupõe que Joaquim é inteligente); "É tão fácil entrar em 
transe assim como fechar os olhos e dormir" (pressupõe ser fácil fechar os olhos e-automaticamente - dormir).

10. Repetição de palavras que contenham teor de insinuação como também, novamente, de novo, outra vez: "Se ele me provocar novamente, terei de agredi-lo" (pressupõe uma provocação anterior); "Se ela também vier, terei de arrumar mais um lugar à mesa" (pressupõe que mais alguém virá).

11. Verbos e advérbios de teor repetitivo como repetir, retornar, refazer, recolocar: "Após a reforma recolocaremos as cortinas" (pressupõe que as cortinas já foram colocadas alguma vez); "Ela se fartou de sobremesa repetidamente" (pressupõe que já se fartara de sobremesa anteriormente).

12. Qualificadores (qualifyers) como apenas, exceto, mesmo: "Apenas João sabia a verdade" (pressupõe que João sabia a verdade); "Todos sabiam a verdade, exceto João" (pressupõe que João não sabia a verdade).

13. Verbos que representam mudança de lugar (change-of-place verbs) como ir, partir, chegar, voltar, entrar, sair: "Se João sair sozinho, facilmente se perderá" (pressupõe que João se encontra em algum lugar); "Se você voltar para a casa de sua mãe, está tudo acabado entre nós" (pressupõe que a pessoa não se encontra na casa de sua mãe).

14. Verbos e advérbios indicativos de ação temporal (change-of-time verbs and adverbs) como começar, terminar, parar, continuar, já, ainda - "Pode continuar estudando" (pressupõe que a pessoa estava estudando, embora pudesse estar simplesmente lendo um livro ou vendo um álbum de fotografias); ou "Você ainda gosta de futebol?" (pressupõe que a pessoa apreciava este esporte anteriormente).

15. Verbos que representam mudança de estado (change-of-state verbs) como mudar, transformar, tornar-se: "Tinja os cabelos de louro e torne-se uma mulher sensual" (pressupõe que a mulher não era sensual anteriormente); "Transforme suas habilidades em dinheiro" 
(pressupõe que a pessoa não ganhava dinheiro com suas habilidades).

16. Verbos e adjetivos de teor diplomático (tactive verbs and adjectives) como excêntrico, consciente, constrangido, saber, compreender, lamentar: "É constrangedor falar alto ao telefone" (pressupõe que tal atitude causa constrangimento às demais pessoas presentes); "Lamento tê-lo feito esperar" (pressupõe que o alguém submeteu outra pessoa a um período de espera).

17. Adjetivos e advérbios que introduzam um comentário - tais como felizmente, necessariamente, afortunadamente: "Felizmente você já sabe do que se trata" pressupõe o conhecimento do interlocutor sobre o assunto em questão; ou "Não é preciso, necessariamente, que você me conte os detalhes" (porque eu já os pressuponho...). Os advérbios de modo, especialmente, potencializam o sentido do que vem a seguir, conferindo, por vezes, novo significado à frase: "Seu cabelo é estranhamente liso" mergulha o interlocutor num mar de dúvidas, passando este a pressupor: "Isto é bom ou ruim?", diferentemente da simples declaração "Seu cabelo é liso".

18. Cláusulas contrafactuais com efeito condicionante (counterfactual conditional clauses) obtidas através do emprego de verbos no tempo subjuntivo como em "Se você tivesse ouvido sua mãe, não estaria nesta situação constrangedora" (pressupõe que a pessoa não ouviu as recomendações de sua mãe e foi penalizada por isso).

19. Flexão de verbo em tempo futuro que contrarie a expectativa - ou a ação - presente (contrary-to-expectation should) como em "Quando você decidir contar a verdade, bastará me ligar" (pressupõe que o interlocutor não sabe a verdade, mas quer e espera saber).

20. Restrições seletivas como "Se Darcy ficar grávida, ficarei surpresa" (pressupõe que Darcy é mulher - quando o nome é utilizado tanto para pessoas do sexo feminino quanto do masculino. Este exemplo não tem um correspondente ideal em língua portuguesa, como ocorre no inglês, cujo exemplo apresentado é "If my professor gets 
pregnant, I'll be disappointed". Em português, substantivos comuns de dois gêneros geralmente são designados por um artigo, adjetivo ou pronome que o antecede como em "Se minha colega ficar grávida, será substituída".

21. Perguntas que admitem uma resposta direta como "Quem está com o dinheiro?" (pressupõe que alguém está com o dinheiro).

22. Perguntas de negação (negative questions): "Você não quer falar comigo?" (pressuponho que você queira falar comigo, mas não o faz por algum motivo especial).

23. Perguntas retóricas: "Quem se preocupa se ela vai à aula ou não?" (pressupõe a preocupação por parte de alguém).

24. Falsa negativa: "Imagino que você não esteja tendo um caso" (pressupõe que a pessoa esteja tendo um caso).

No apêndice da tradução para o português do Modelo Milton (BANLDER; GRINDER, 1984), Bandler e Grinder apresentam ainda três padrões de pressuposições que não figuram no modelo proposto em Patterns I:

25. Emprego da expressão "ou" - "Você pode me entregar o relatório quarta-feira no final do expediente ou na quinta, à primeira hora"; tal comando pressupõe que a pessoa, de fato, estará apta a entregar o trabalho nas datas sugeridas - e que concorda com isso!

26. Predicados de conscientização - verbos como saber, perceber, notar, conscientizar-se permitem interpretar o enunciado seguinte como um pressuposto: "Você sabe o quanto este relatório é importante para mim"; ou "Você percebeu que ninguém concorda com seu ponto de vista".

27. Uso de advérbios e adjetivos - "Você deve estar curioso para saber o que vem depois" (pressupõe a curiosidade do interlocutor ao mesmo tempo que a desperta); ou "Quão rapidamente você é capaz de entregar o relatório?” - (pressupõe que a pessoa é, sem dúvida, capaz de elaborar o relatório). 
Segundo Bandler e Grinder, quanto mais informações forem pressupostas "mais difícil será para o ouvinte deslindar a sentença e pôr em questão qualquer um dos pressupostos". Como no exemplo por eles elaborado:

E não sei quanto tempo será preciso para você tomar conhecimento das aprendizagens que seu inconsciente já realizou, porque não é importante que você saiba antes de ter, confortavelmente, dado prosseguimento ao processo de relaxamento e de haver consentido que o outro lado seu aprenda alguma coisa de mais útil e gostoso por você (BANDLER; GRINDER, 1984, p. 283, destaques da Autora).

Erickson usava as pressuposições com maestria conferindo, assim, um poder singular a seus enunciados frente aos clientes. Apesar de parecerem um tanto óbvias nos exemplos apresentados, inseridas no contexto de uma sessão terapêutica, promovem efeitos inusitados, como será demonstrado nas análises dos Casos Selecionados apresentados adiante.

\section{Padrões de eliciação indireta}

Os padrões de eliciação indireta são úteis na obtenção de respostas específicas de forma indireta, sem a necessidade de empreender questionamentos ostensivos. Observa-se que, da mesma forma que Bandler e Grinder destacam que os processos de generalização e eliminação podem ser considerados formas específicas de distorção, assim também alguns dos padrões de eliciação indireta parecem induzir pressuposições. Apresentam as seguintes subcategorias:

1. Ordens embutidas - ao invés de apresentar abertamente as instruções para que o cliente as siga, tais procedimentos induzem um resultado final almejado: "Tome duas pílulas ao dia e você se sentirá melhor" (Você deve se sentir melhor); ou "Após alguns segundos, você começará a sentir-se relaxado" (Você deve relaxar).

2. Assinalação de análogos - este procedimento destaca um reforço não-verbal num dado comando (seja ele explícito ou uma ordem embutida) tal como um gesto, modulação da voz, velocidade da fala. Por exemplo, ao dizer "Após alguns segundos respirando pausadamente, você começará a sentir-se re-la-xa-do..." (baixando o 
tom de voz, reduzindo a velocidade da fala e fazendo um gesto de suave ondulação com uma das mãos).

3. Perguntas embutidas - representam um questionamento, mas não admitem a forma interrogativa: "Estou curioso para saber o que hipnose representa para você..."; ou "Fico me perguntando o que, realmente, você pensa de mim".

4. Ordens negativas - um comando negativo induz, inicialmente, a representação da contra-ordem positiva. "A negação não existe como experiência primária de imagens visuais, de sons e de sentimentos; negação só existe como experiência secundária: na representação simbólica da linguagem e das matemáticas" (BANLDER; GRINDER, 1984, P. 284). Assim, quando se diz "Não pense numa maçã vermelha", a imagem é primeiramente processada para, em seguida, ser negada ou apagada. Erickson usava este comando quando queria que alguém resistente estivesse presente como auxiliar no tratamento de um paciente; ao emitir uma ordem negativa do tipo "Diga a seu marido que não quero que ele participe das sessões", recebia como resposta, na sessão seguinte, a presença do marido "desprezado" ou "impedido" de participar.

5. Postulados de conversação - perguntas que admitiriam respostas do tipo sim/não, mas que induzem um feedback mais profundo. Como nas "conversas de elevador": quando alguém diz "Será que vai chover?" recebe, como resposta, um comentário em vez de simples sim ou não ("O homem do tempo disse que vem aí uma frente fria"; ou "Detesto chuva!"). Da mesma maneira, respostas a perguntas do tipo: "Tem horas?" ou "Sabe o que vai passar na tv hoje à noite?" admitem respostas mais abrangentes como "São dez e meia" ou "Novela, futebol e telejornal".

6. Ambiguidade - ocorre quando uma palavra ou enunciado admitem mais de um significado. Ao gerar um grau moderado de confusão ou desorientação, pode induzir estados alterados, sendo de grande valia para a hipnose. No Metamodelo, um dos principais propósitos é esclarecer as ambiguidades. Já no Modelo Milton, estas possibilitam 
ao cliente encontrar mais de um significado para a palavra ou o enunciado proferidos, resultando em eventuais "soluções". O uso proposital de nominalizações, verbos não-específicos, índices referenciais não-especificados e omissões pode intensificar a ambiguidade da mensagem. Os autores destacam:

a) A ambiguidade fonológica - o uso proposital de homófonos como em "Aquele cachorro não gosta de mim" (dependendo do contexto, o locutor pode estar-se referindo a um animal ou a um homem, no sentido pejorativo); ou, como na piada a respeito da uma dançarina de ritmos populares, que inquirida por um famoso entrevistador de TV sobre "seu hobby preferido" teria respondido "azul de seda" (numa referência a um robe, peça do vestuário).

b) A ambiguidade sintática - "O hipnotizador hipnotizar pode ser complicado" (o que pode ser complicado: o hipnotizador conseguir hipnotizar alguém ou ser hipnotizado?); ou "João tirou a camisa de Paulo" (a camisa que Paulo usava ou a camisa que era de Paulo - e João estava vestindo?).

c) A ambiguidade de escopo - "Participarão do seminário vendedores e atendentes muito competentes" (somente os atendentes são muito competentes ou podemos estender o elogio aos vendedores?).

d) A ambiguidade de pontuação - se destaca quando dois enunciados são apresentados em sequência, sendo que a última palavra do primeiro é repetida no início do segundo: "Se eu confiar esta quantia a você, você promete que não gasta tudo de uma vez?" Ou quando o significado de dois enunciados se confunde pela ausência ou inadequação da pontuação - especialmente na enunciação verbal não pontuada: "O sonho acabou com a crise" ("O sonho / acabou com a crise" ou "O sonho acabou / com a crise"?). 


\section{Padrões de metáfora}

Bandler e Grinder destacam que, apesar de existirem vários padrões para o uso de metáforas, dois deles são os mais eficientes para a constituição do Modelo Milton:

33. Violações das restrições seletivas - atribuição de qualidades a alguém ou a algo que, naturalmente, não poderia contar com essas qualidades. "Pitty era uma cachorrinha tão esperta que conversava comigo" (é claro que a cachorra não falava, mas o significado de sua comunicação era "como se fosse" verbal, de tão eficiente). "As pedras da sua gigantesca ignorância ser-me-ão leves como plumas" (pedras, em geral, não são leves, principalmente se forem gigantes como a ignorância do interlocutor; a metáfora serve para dizer que o locutor não será atingido, não importa a carga pejorativa que se abata sobre ele).

34. Citações - formulação de uma afirmação como se tal já tivesse sido empregada com sucesso por alguém num outro tempo e lugar; permitem apresentar qualquer conteúdo sem implicar responsabilidade do locutor sobre o enunciado; o interlocutor, por sua vez, será capaz de identificar-se inconscientemente com a mensagem ou mesmo interpretá-la sem se sentir enredado/manipulado por seu conteúdo: "Minha mãe sempre dizia: cautela e caldo de galinha não fazem mal a ninguém" (= Seja cauteloso!); "Soube de um funcionário que dois anos atrás desobedeceu a chefia e foi demitido na hora!" (= Seja obediente!).

A identificação e compreensão das categorias do Modelo Milton permitem localizálas em meio aos padrões de linguagem correntes no dia-a-dia. Tais modelos subvertem as estruturas linguísticas tradicionalmente aprendidas - segundo as regras da gramática, da sintaxe e da semântica -, promovendo nas pessoas efeitos hipnóticos instantâneos.

Cabe observar que todas as categorias e subcategorias ora apresentadas faziam parte do discurso terapêutico de Erickson que, de maneira inconsciente, explorava as potencialidades da língua para induzir seus clientes às ações que julgava adequadas, para neles promover as mudanças necessárias. Tais regularidades, 
observadas por seus seguidores, em especial Bandler e Grinder, organizadores do Modelo Milton, encontram-se agora disponíveis a todos aqueles que queiram induzir transes - e até mesmo a ações que induzam a novos comportamentos "artisticamente", reduzindo os índices de conflito - tanto interiormente, pelo próprio cliente, como também entre este e seu terapeuta.

O próximo capítulo vai elaborar, através da análise de casos, uma base empírica para se verificar tais regularidades no modelo terapêutico de Erickson, principal objetivo desta tese. 


\section{MODELO MILTON: ANÁLISES DE CASOS SELECIONADOS}

"E minha voz seguirá com você onde quer que você vá..."

MILTON ERICKSON

A realização dos objetivos propostos para esta tese direciona o foco das análises para o exame da vida de Milton Erickson, de sua obra como um todo, de sua aproximação e distanciamento com a Psicanálise e de suas técnicas terapêuticas. Os capítulos anteriores devem ter informado ao leitor sobre o lugar de Milton Erickson como autor de uma das grandes narrativas da Psicologia, bem como sobre sua compreensão da subjetividade humana, sua visão acerca dos problemas humanos denominados clínicos e as soluções por ele apontadas. A análise da obra de Erickson seria tarefa meramente especulativa se parasse nesse escrutínio teórico. Para complementá-la, uma análise empírica da própria obra ericksoniana é apresentada neste capítulo, tomando por base três casos clínicos narrados pelo próprio Erickson, como expressão representativa de sua obra. Pretende-se, nesta etapa, criar alguma fundamentação empírica demonstrável a partir do próprio discurso ericksoniano em ação, que confirme e explicite os juízos sobre sua obra apresentados nos capítulos anteriores. Assim, a visão do escopo desta tese fica completa.

Para melhor compreensão das aplicações das categorias e subcategorias do Metamodelo e do Modelo Milton apresentadas no capítulo anterior, foram selecionados três casos como estratégia de pesquisa empírica em que o discurso terapêutico de Erickson é analisado conforma será explicitado a seguir. $O$ texto integral correspondente a cada um deles está publicado no Anexo I.

\subsection{Estratégia}

O método de Erickson explora as potencialidades do discurso, permitindo ao indivíduo o confronto com a sua própria realidade e com a realidade maior ao redor dele. Em vista disso, o exame do discurso ericksoniano pode ser realizado através 
de ampla diversidade de caminhos. Podem ser analisadas suas regularidades semânticas e sintáticas, a evolução histórica de seu pensamento ou suas técnicas de persuasão e de hipnose. Todas as alternativas possíveis permitem a compreensão de sua obra, embora a partir de pontos de vista distintos. Assim, a comparação entre os diversos caminhos possíveis revelou que a identificação das categorias de análise que a literatura identifica em seu método terapêutico seria um ponto de vista que ofereceria elementos para conhecimento da racionalidade ericksoniana e de sua forma de compreensão da subjetividade humana, da relação entre esta e o mundo ao redor, bem como dos instrumentos terapêuticos para intervenção que têm em vista a cura. Para tanto, tomou-se como objeto de análise os casos terapêuticos descritos e apresentados pelo próprio Erickson, recolhidos por Haley (1991). Embora Erickson tenha publicado incansavelmente ao longo de sua vida, são os casos clínicos que oferecem uma visão global de sua obra, seus fundamentos epistemológicos e sua tradução na prática profissional como terapeuta.

A realização dessa tarefa exigiu a seleção dos casos e a elaboração de uma metodologia de análise dos mesmos. A escolha dos casos foi realizada quase que aleatoriamente após diversas leituras flutuantes dos casos selecionados por Haley (1991). O exame prévio dos casos clínicos oferecidos pelo próprio Erickson revelou que seus conceitos e técnicas podiam ser neles observados, embora, em alguns, de forma mais completa que em outros. Em vista disso, foram escolhidos três casos nos quais seria possível identificar a obra ericksoniana como uma espécie de laboratório de observação da mesma.

É sabido que a análise do discurso é um estudo peculiar, que se prende ao significado que as palavras adquirem nos contextos específicos em que se apresentam. Em vista disso, é preferível que os sentidos sejam apreciados nos textos, a partir da língua original. No entanto, nesta tese, optou-se por trabalhar com os textos traduzidos, mesmo correndo-se o risco de certas imprecisões da tradução, pois um dos objetivos da tese é mostrar a universalidade dos padrões ericksonianos, aplicáveis a qualquer idioma. Assim, tentou-se, sempre que possível, evidenciar exemplos da língua portuguesa que se aproximassem tanto quanto possível das palavras e construções sintático-semânticas apresentadas no discurso terapêutico de Erickson na sua língua nativa, o inglês americano. O exame prévio dos três casos mostrou elementos suficientemente representativos da obra de Erickson e das 
categorias de análise propostas por Bandler e Grinder.O passo seguinte foi a elaboração da metodologia de análise dos casos, que é apresentada a seguir.

Conforme explicitado nos capítulos anteriores, Milton Erickson utilizava a hipnose e um conjunto de táticas terapêuticas que podem ser assumidas como o eixo de sua proposta, de acordo com o conteúdo detalhado no capítulo 3. A regularidade em seu trabalho inspirou o desenho de uma metodologia que poderia aqui ser denominada de integração das leituras vertical e horizontal da obra ericksoniana nos três casos selecionados.

Entende-se por leitura vertical o escrutínio de cada caso em seu próprio contexto, no qual são apontadas as tecnicalidades e categorias da obra ericksoniana. Desse escrutínio, se pode apreender o que é a grande narrativa de Milton Erickson e o que ele propõe como intervenção terapêutica. Cada um dos três casos é, nesta etapa, submetido a essa varredura separadamente.

Para a realização dessa estratégia de pesquisa, os casos foram transcritos de modo a diferenciar as falas e comentários de Erickson, bem como as falas dos pacientes durante as sessões. Cada uma dessas falas - comentários de Erickson, falas dos pacientes e falas de Erickson - foi registrada numa coluna diferente, de tal forma a tornar possível a visualização dos conteúdos e da dinâmica das relações entre o terapeuta e o paciente e entre o terapeuta e a sociedade.

Nessa estrutura dos casos, em três colunas, a leitura vertical foi realizada mediante a interpretação das passagens nas quais ocorriam as categorias e subcategorias do Metamodelo bem como as categorias e subcategorias do Modelo Milton apresentadas no capítulo 3. Em cada uma das passagens, as categorias foram identificadas por uma sigla acompanhada pelo número e o nome da subcategoria correspondente. Isto capacita o leitor a verificar a presença das técnicas ericksonianas na sequência em que são apresentadas, em cada um dos casos.

Entende-se por leitura horizontal a trajetória inversa, ou seja, a identificação dos conceitos e técnicas nos três casos apresentados, porém, simultaneamente. $\mathrm{O}$ objetivo é expor a transversalidade dos conceitos para as mais diferentes situações clínicas.

A leitura horizontal, diferentemente, foi realizada através da busca, nos três casos, das recorrências de cada subcategoria a elas consignadas. Nessa leitura, pode-se 
observar o "comportamento" da referida subcategoria de análise nas ocorrências destacadas dos três casos escolhidos, apreendendo-se mais facilmente seu efeito sobre os clientes de forma generalizada, independentemente do contexto em que se aplica.

A metodologia ora apresentada inspirou-se em técnicas tradicionais como a análise de conteúdo e a análise do discurso.

\subsection{Descrição dos casos selecionados}

O primeiro caso selecionado apresenta Ann, uma jovem de 21 anos com a autoestima destruída pelo histórico familiar, carente de afeto, de estudo e de oportunidades profissionais.

Logo à primeira consulta, Erickson promove intenso espelhamento verbal, exagerando as deficiências da cliente, de modo a fazê-la sentir quão "sincero e confiável" ele seria, dizendo-lhe "toda a verdade" a seu respeito. Sessão após sessão, o terapeuta passa a atribuir a ela as mais inusitadas tarefas, construindo uma narrativa que a conduz a profundas reflexões sobre sua aparência e trajetória de vida, conseguindo, por fim, recuperar sua autoestima.

O segundo caso refere-se a um menino de dez anos com problema de incontinência urinária, que chegou ao consultório de Erickson literalmente arrastado pelos pais. A fim de estabelecer rapport com a criança, o terapeuta impede a entrada dos mesmos na sessão, compartilhando com seu jovem cliente uma série de comportamentos infantis de contestação, partindo do ato de gritar como forma de se rebelar contra a situação, desviando, a seguir, sua atenção para assuntos "de menino" - a começar pelos esportes praticados por ele, até criar a oportunidade de Ihe apresentar detalhes sobre sua própria anatomia - utilizando metáforas para explicar a importância dos músculos para a retenção da urina, tendo alcançado sucesso na terapia sem se ocupar de discutir diretamente a questão envolvida.

Por fim, no terceiro caso, apresenta-se um menino de doze anos que havia transformado uma espinha em grave ulceração, por mexer nela constantemente. Após ouvir sugestões médicas sobre o possível agravamento da ferida, sem acatá- 
las, o menino passou a ser castigado pelo pai, sendo privado de alguns de seus brinquedos favoritos. Como a mãe não concordava com o rigor dos castigos, encaminhou o menino a Erickson, com o consentimento do pai.

Examinando o caso e identificando a questão de poder envolvida no relacionamento entre pai e filho, Erickson designou tarefas para ambos - uma espécie de "castigo produtivo", já que havia criticado duramente o pai quanto à ineficácia de subtrair do menino os seus brinquedos mais queridos visando à cura. Assim, ordenou que o menino aprimorasse sua caligrafia e ortografia - ele costumava suprimir algumas letras quando escrevia - copiando textos incansavelmente e, ao pai, que cuidasse do jardim - tarefa antes designada ao menino.

Determinou também uma curiosa inversão de papéis - o menino deveria inspecionar o trabalho do pai, quando antes ocorria o contrário. E associou a escrita caprichada à cura da úlcera - quanto mais se dedicasse a escrever, mais rapidamente estaria curado.

Empregando, em cada caso, inúmeras das categorias e subcategorias anteriormente apresentadas, é possível perceber os efeitos de cada uma delas no processo terapêutico em cada um dos casos. Alguns padrões são empregados com notável recorrência, outros em menor constância, havendo mesmo alguns deles ausentes na amostra trabalhada. Importante, porém, observar como cada um deles é empregado no momento adequado, de acordo com o contexto criado por Erickson. Para melhor compreensão, recomenda-se, primeiramente, a leitura completa dos casos no Anexo I, seguida da leitura vertical, em que os casos se encontram também na íntegra, mas com a assinalação das devidas categorias/subcategorias nos contextos pertinentes a cada caso, complementada, posteriormente, pela leitura horizontal, que agrupa exemplos dos três casos a partir de cada categoria/subcategoria. 


\subsection{Análise dos casos selecionados: leitura vertical}

Nesta seção, é apresentada a primeira parte da metodologia, a leitura vertical. Para a compreensão da leitura vertical sob a ótica ericksoniana, após cada ocorrência é apresentada em negrito, entre colchetes - [ ] - a sigla referente à categoria destacada, seguida do número e do nome correspondentes à(s) subcategoria(s) identificada(s) no trecho.

SIGLAS (referentes às categorias):

$\mathbf{C l}=$ Coleta de informações

LME = Limites do modelo do emissor

MFS = Má-formação semântica

$\mathbf{P}=$ Pressuposições

PEI = Padrões de eliciação indireta

Caso 1 - Ann

\begin{tabular}{|c|c|c|}
\hline NARRAÇÃO (ERICKSON) & FALA (ANN) & FALA (ERICKSON) \\
\hline $\begin{array}{l}\text { Certa feita, um problema mais } \\
\text { grave apresentou-se a Erickson. } \\
\text { Uma mulher de vinte e um anos } \\
\text { lhe telefonou pedindo ajuda, } \\
\text { dizendo ter certeza de que ele } \\
\text { não a receberia. Quando chegou } \\
\text { ao consultório, disse: }\end{array}$ & $\begin{array}{l}\text { É como eu lhe disse, agora } \\
\text { vou embora. Meu pai está } \\
\text { morto, minha mãe está morta, } \\
\text { minha irmã está morta, e isto } \\
\text { é tudo que me resta. }\end{array}$ & \\
\hline $\begin{array}{l}\text { Eu pedi com insistência que se } \\
\text { sentasse e, após pensar } \\
\text { rapidamente, percebi que a única } \\
\text { maneira possível de me comunicar } \\
\text { com ela era através da dureza e da } \\
\text { brutalidade. Teria de usar de } \\
\text { brutalidade para convencê-la de } \\
\text { minha sinceridade. Ela interpretaria } \\
\text { mal qualquer amabilidade e não } \\
\text { conseguiria acreditar na linguagem } \\
\text { cortês [MFS - } 2 \text { - Leitura da } \\
\text { mente]. Teria que convencê-la } \\
\text { totalmente de que a compreendia } \\
\text { e reconhecia seu problema, e que } \\
\text { não tinha medo de falar aberta, } \\
\text { livremente, sem nenhuma emoção } \\
\text { e com franqueza. }\end{array}$ & & \\
\hline
\end{tabular}

Quadro 3 - Caso Ann (continua) 


\section{(continuação)}

\begin{tabular}{|c|c|c|}
\hline NARRAÇÃO (ERICKSON) & FALA (ANN) & FALA (ERICKSON) \\
\hline $\begin{array}{l}\text { Retomei sua história } \\
\text { resumidamente e, a seguir, fiz } \\
\text { duas perguntas importantes: }\end{array}$ & & $\begin{array}{l}\text { Qual é sua altura e seu peso? } \\
\text { [P - 21 - Pergunta que admite } \\
\text { uma resposta direta] }\end{array}$ \\
\hline $\begin{array}{l}\text { Com um olhar de sofrimento } \\
\text { extremo, ela respondeu: }\end{array}$ & $\begin{array}{l}\text { Tenho um metro e sessenta. } \\
\text { Peso noventa e cinco quilos. } \\
\text { Sou uma bobalhona gorda } \\
\text { comum. Ninguém olharia } \\
\text { para mim, a não ser com } \\
\text { repulsa }\end{array}$ & \\
\hline $\begin{array}{l}\text { Este comentário me ofereceu a } \\
\text { abertura conveniente, e eu lhe } \\
\text { disse: }\end{array}$ & & 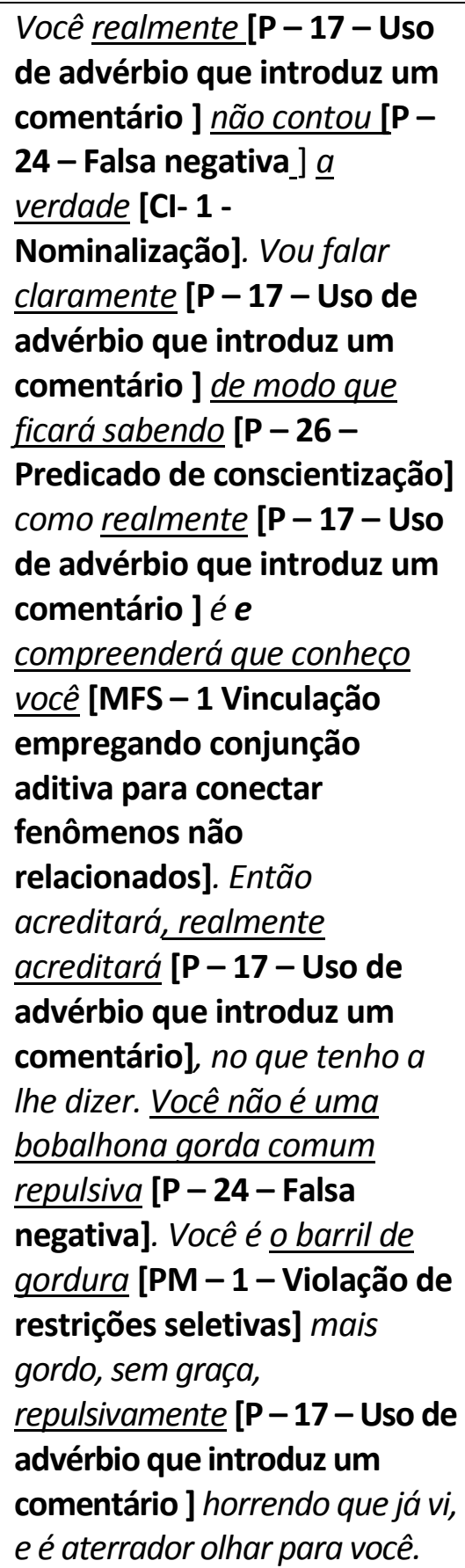 \\
\hline
\end{tabular}


(continuação)

\begin{tabular}{|c|c|c|}
\hline NARRAÇÃO (ERICKSON) & FALA (ANN) & FALA (ERICKSON) \\
\hline & & 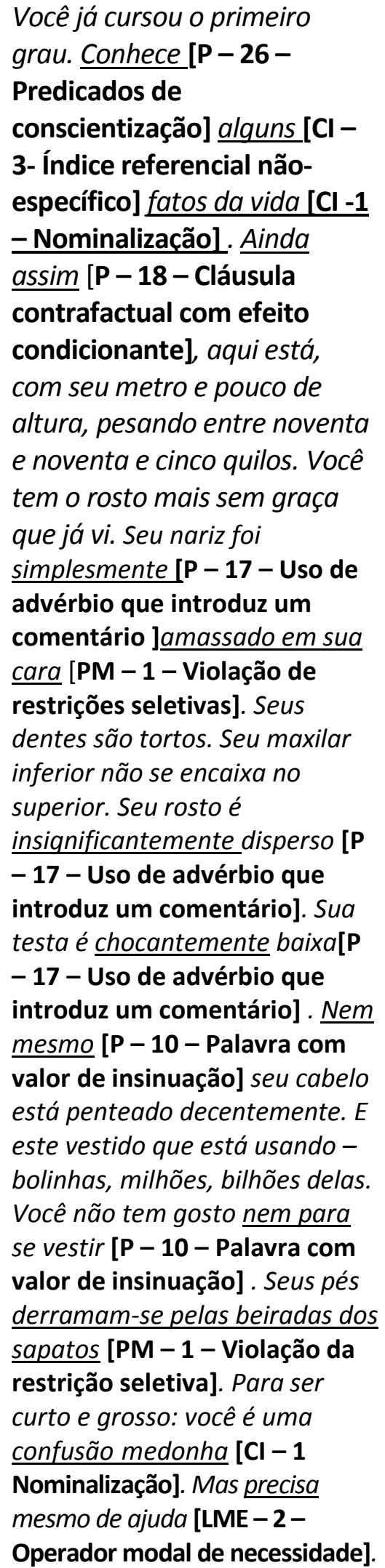 \\
\hline
\end{tabular}

(continua) 
(continuação)

\begin{tabular}{|c|c|c|}
\hline NARRAÇÃO (ERICKSON) & FALA (ANN) & FALA (ERICKSON) \\
\hline & & 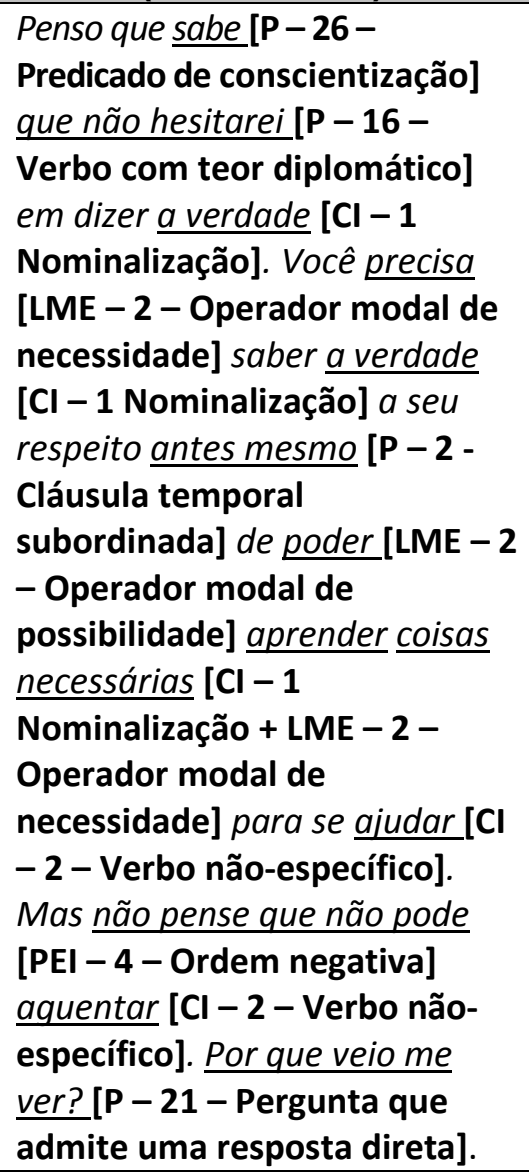 \\
\hline Ela respondeu: & $\begin{array}{l}\text { Pensei que talvez pudesse ser } \\
\text { hipnotizada para conseguir } \\
\text { perder peso }\end{array}$ & \\
\hline Respondi: & & 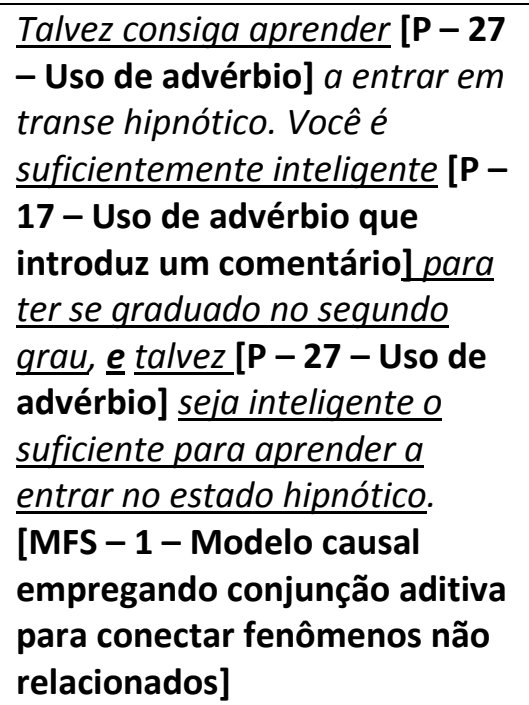 \\
\hline
\end{tabular}

(continua) 
(continuação)

\begin{tabular}{|c|c|c|}
\hline NARRAÇÃO (ERICKSON) & FALA (ANN) & FALA (ERICKSON) \\
\hline & & 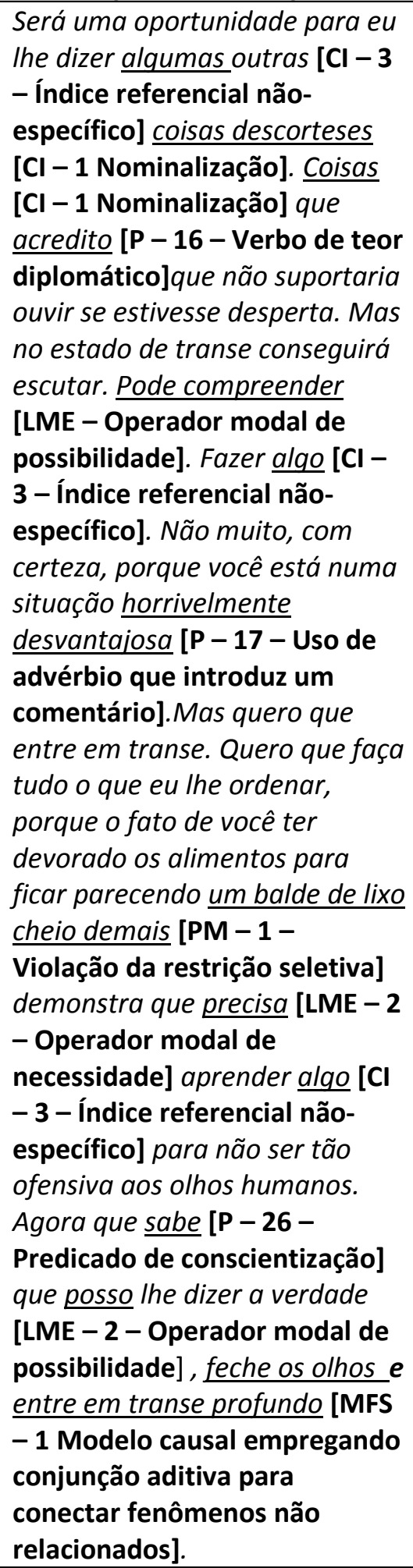 \\
\hline
\end{tabular}


(continuação)

\begin{tabular}{|c|c|c|}
\hline NARRAÇÃO (ERICKSON) & FALA (ANN) & FALA (ERICKSON) \\
\hline & & 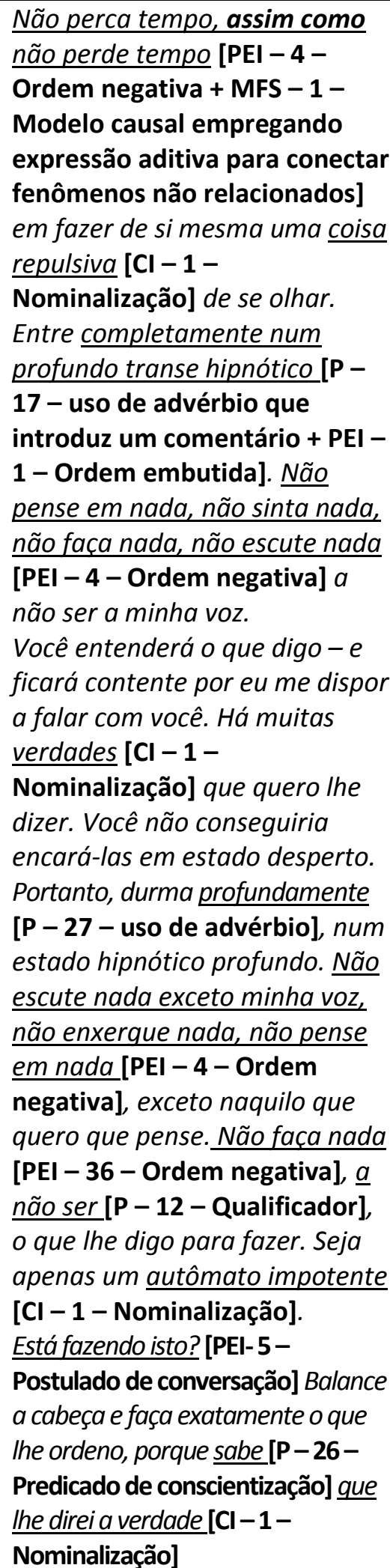 \\
\hline
\end{tabular}


(continuação)

\begin{tabular}{|c|c|c|}
\hline NARRAÇÃO (ERICKSON) & FALA (ANN) & FALA (ERICKSON) \\
\hline & & $\begin{array}{l}\text { A primeira coisa que farei [P-7- } \\
\text { Ordenação] é fazer com que-ou } \\
\text { melhor, ordenar a você - conte } \\
\text { certos fatos a seu respeito. Você } \\
\text { pode [LME - 2-Operador modal } \\
\text { de possibilidade] falar, embora } \\
\text { esteja em transe profundo. } \\
\text { Responda a cada pergunta de } \\
\text { maneira simples, mas } \\
\text { informativa. O que há de } \\
\text { importante sobre seu pai?" }\end{array}$ \\
\hline Sua resposta foi: & $\begin{array}{l}\text { Ele me odiava. Era um bêbado. } \\
\text { Vivíamos em guerra. Ele } \\
\text { costumava me chutar. Isto é } \\
\text { tudo que lembro de meu pai. } \\
\text { Bêbado, batendo em mim, me } \\
\text { chutando, me odiando”. "E sua } \\
\text { mãe?". "Era igual, mas } \\
\text { morreu primeiro. Ela me } \\
\text { odiava ainda mais de que meu } \\
\text { pai. Me tratava ainda pior do } \\
\text { que ele. Só me mandaram ao } \\
\text { ginásio porque sabiam que eu } \\
\text { odiava a escola. Tudo o que eu } \\
\text { podia fazer durante o ginásio } \\
\text { era estudar. Eles me fizeram } \\
\text { morar na garagem com minha } \\
\text { irmã. Ela nasceu deficiente. } \\
\text { Era pequena e gorda. Tinha a } \\
\text { bexiga do lado de fora do corpo. } \\
\text { Estava sempre doente. Tinha } \\
\text { uma doença dos rins. Nós nos } \\
\text { amávamos. Só tínhamos uma à } \\
\text { outra para amar. Quando ela } \\
\text { morreu da doença renal, eles } \\
\text { disseram: 'Ótimo'. Não me } \\
\text { deixaram ir ao enterro. Apenas } \\
\text { enterraram a única coisa que } \\
\text { eu amava. Eu era uma caloura } \\
\text { no ginásio. No ano seguinte, } \\
\text { minha mãe se matou de tanto } \\
\text { beber. E meu pai se casou com } \\
\text { uma mulher pior do que minha } \\
\text { mãe. Ela não me deixava entrar } \\
\text { em casa. }\end{array}$ & \\
\hline
\end{tabular}


(continuação)

\begin{tabular}{|c|c|c|}
\hline NARRAÇÃO (ERICKSON) & FALA (ANN) & FALA (ERICKSON) \\
\hline & $\begin{array}{l}\text { Trazia um mingau para a } \\
\text { garagem e me fazia comer. } \\
\text { Dizia que eu podia me } \\
\text { consumir até morrer. Que já } \\
\text { iria tarde. Era uma bêbada } \\
\text { como minha mãe. A assistente } \\
\text { social também não gostava } \\
\text { de mim, mas me encaminhou } \\
\text { para fazer alguns exames } \\
\text { médicos. Os médicos não } \\
\text { gostavam de me tocar. Agora } \\
\text { minha madrasta e minha } \\
\text { irmã estão mortas. O seguro } \\
\text { social me mandou procurar } \\
\text { um emprego. Consegui um, } \\
\text { onde tenho que esfregar o } \\
\text { chão. Os homens do lugar } \\
\text { caçoam de mim. Eles } \\
\text { oferecem dinheiro uns aos } \\
\text { outros para ter uma relação } \\
\text { comigo, mas ninguém, aceita. } \\
\text { Não sirvo para nada. Mas } \\
\text { gostaria de viver. Tenho onde } \\
\text { morar. Um barracão velho. } \\
\text { Não ganho muito - como } \\
\text { papa de farinha de milho e } \\
\text { batatas, ou algo assim. } \\
\text { Pensei que talvez pudesse me } \\
\text { hipnotizar e fazer algo por } \\
\text { mim. Mas acho que não vai } \\
\text { adiantar nada. }\end{array}$ & \\
\hline $\begin{array}{l}\text { Da maneira mais insensível e } \\
\text { peremptória perguntei: }\end{array}$ & & $\begin{array}{l}\text { Sabe o que é uma biblioteca? } \\
\text { [PEI - } \mathbf{5} \text { - Postulado de } \\
\text { conversação] Quero que vá a } \\
\text { uma biblioteca e retire livros de } \\
\text { antropologia. Quero que olhe } \\
\text { todos os tipos chocantes de } \\
\text { mulheres com que os homens se } \\
\text { casam. Há fotografias delas nos } \\
\text { livros da biblioteca. Selvagens } \\
\text { primitivos [P - } \mathbf{d} \text { - Nomes } \\
\text { genéricos] se casarão com } \\
\text { coisas [CI - } \mathbf{1} \text { - Nominalização] } \\
\text { que têm uma aparência pior do } \\
\text { que a sua. }\end{array}$ \\
\hline
\end{tabular}

(continua) 
(continuação)

\begin{tabular}{|c|c|c|}
\hline NARRAÇÃO (ERICKSON) & FALA (ANN) & FALA (ERICKSON) \\
\hline & & $\begin{array}{l}\text { Olhe um livro atrás do outro e } \\
\text { fique curiosa }[\mathrm{Cl}-\mathbf{3} \text { - Índice } \\
\text { referencial não-específico]. } \\
\text { Então leia livros que narrem } \\
\text { como mulheres e homens se } \\
\text { desfiguram, fazem tatuagens, } \\
\text { se mutilam para parecerem } \\
\text { ainda mais horrorosos [P-8 - } \\
\text { Uso de comparativos]. Passe a } \\
\text { maior parte do tempo que } \\
\text { puder na biblioteca. Faça isto } \\
\text { direito e volte em duas } \\
\text { semanas. }\end{array}$ \\
\hline $\begin{array}{l}\text { Eu a despertei do transe com essas } \\
\text { sugestões pós-hipnóticas, e ela saiu } \\
\text { do consultório da mesma maneira } \\
\text { acachapada que tinha entrado. } \\
\text { Voltou duas semanas mais tarde. } \\
\text { Eu lhe disse para não perder tempo } \\
\text { - para entrar em transe profundo } \\
\text { imediatamente. Perguntei se havia } \\
\text { encontrado alguma fotografia que } \\
\text { achasse desagradável. Ela contou } \\
\text { que havia encontrado retrato das } \\
\text { mulheres esteatopígicas dos } \\
\text { hotentotes, e das mulheres com } \\
\text { lábios tipo bico de pato, de } \\
\text { escarificação em algumas tribos } \\
\text { africanas, de estranhos rituais de } \\
\text { mutilação. } \\
\text { Ordenei a ela que se dirigisse para a } \\
\text { área mais movimentada da cidade } \\
\text { (em estado desperto) e observasse } \\
\text { as formas peculiares e as faces das } \\
\text { coisas [CI - 1- Nominalização] com } \\
\text { que os homens se casam. Ela } \\
\text { deveria [LME-2 - Operador } \\
\text { modal de necessidade] fazer isto } \\
\text { durante uma semana. Na semana } \\
\text { seguinte [P-7-Ordenação], } \\
\text { deveria [LME-2 - Operador } \\
\text { modal de necessidade] olhar } \\
\text { formas e faces peculiares das coisas } \\
\text { [CI-3-Índice referencial não- } \\
\text { específico] com que as mulheres se } \\
\text { casam, e se assombrar com isto. }\end{array}$ & & \\
\hline
\end{tabular}

(continua) 


\section{(continuação)}

\begin{tabular}{|c|c|c|}
\hline NARRAÇÃO (ERICKSON) & FALA (ANN) & FALA (ERICKSON) \\
\hline $\begin{array}{l}\text { Obedientemente, ela retornou } \\
\text { para a entrevista seguinte, } \\
\text { entrou em transe à simples } \\
\text { menção do assombro com que } \\
\text { observara mulheres quase tão } \\
\text { sem graça quanto ela usando } \\
\text { alianças. Ela havia visto homens e } \\
\text { mulheres que pareciam marido e } \\
\text { mulher, ambos horrivelmente } \\
\text { gordos e desengonçados. Disse- } \\
\text { Ihe que estava começando a } \\
\text { aprender alguma coisa [Cl - } 3 \text { - } \\
\text { Índice referencial não-específico } \\
\text { + Cl - } 1 \text { - Nominalização]. } \\
\text { Sua tarefa seguinte era ir à } \\
\text { biblioteca e ler todos os livros } \\
\text { que conseguisse sobre a história } \\
\text { da cosmetologia - descobrir o } \\
\text { que constitui a beleza desejável } \\
\text { aos olhos humanos. Ela fez uma } \\
\text { ampla pesquisa e, na semana } \\
\text { seguinte, entrou no consultório } \\
\text { sem timidez, mas ainda } \\
\text { continuava vestida com a roupa } \\
\text { de bolinhas. Então disse-lhe que } \\
\text { voltasse à biblioteca e se } \\
\text { dedicasse aos livros que } \\
\text { tratavam e costumes humanos, } \\
\text { vestuário e aparência - para } \\
\text { descobrir alguma coisa [Cl - } \mathbf{3} \text { - } \\
\text { Índice referencial não-específico } \\
+ \text { Cl - } 1 \text { - Nominalização] } \\
\text { retratada que tivesse, no } \\
\text { mínimo, quinhentos anos e ainda } \\
\text { fosse bonita . Ann voltou, } \\
\text { desenvolveu um transe assim } \\
\text { que entrou no consultório, } \\
\text { sentou-se e falou longo tempo } \\
\text { sobre o que havia visto nos } \\
\text { livros. } \\
\text { Disse-Ihe que sua próxima tarefa } \\
\text { seria muito difícil. Durante duas } \\
\text { semanas, ela deveria entrar na } \\
\text { primeira loja de vestuário } \\
\text { feminino que encontrasse, } \\
\text { depois noutra, usando seu } \\
\text { assustador vestido de bolinhas. }\end{array}$ & & \\
\hline
\end{tabular}

(continua) 
(continuação)

\begin{tabular}{|c|c|c|}
\hline NARRAÇÃO (ERICKSON) & FALA (ANN) & FALA (ERICKSON) \\
\hline $\begin{array}{l}\text { Deveria perguntar à vendedora o } \\
\text { que deveria usar - perguntar tão } \\
\text { séria e honestamente que } \\
\text { obteria uma resposta. Depois } \\
\text { desta tarefa, ela relatou que } \\
\text { várias mulheres mais velhas a } \\
\text { haviam chamado de "queridinha" } \\
\text { e Ihe explicado por que não } \\
\text { deveria usar milhões e milhões } \\
\text { de bolinhas. Explicaram-Ihe por } \\
\text { que não deveria usar vestidos } \\
\text { que não lhe caíam bem e } \\
\text { acentuavam sua gordura. } \\
\text { A próxima tarefa era gastar duas } \\
\text { semanas com pensamentos } \\
\text { obsessivos: por que ela, que } \\
\text { deveria ter nascido com menos } \\
\text { de três quilos, teria adquirido } \\
\text { aquela enorme quantidade de } \\
\text { gordura? Por que havia se } \\
\text { enrolado em gordura? [P - } 23 \text { - } \\
\text { Perguntas retóricas] No relato } \\
\text { desta tarefa, ela declarou que } \\
\text { não conseguiria chegar a } \\
\text { nenhuma conclusão. } \\
\text { De novo em estado de transe, } \\
\text { dei-lhe outra tarefa. Desta vez, } \\
\text { descobrir se realmente havia } \\
\text { alguma razão para ela pesar o } \\
\text { que pesava - querer saber como } \\
\text { seria sua aparência se pesasse } \\
\text { somente sessenta quilos e se } \\
\text { vestisse de modo apropriado [P - } \\
\text { 19- Flexão de verbo em tempo } \\
\text { futuro que contrarie a ação } \\
\text { presente]. Ela deveria acordar no } \\
\text { meio da noite com esta questão } \\
\text { em mente, para em seguida } \\
\text { tornar a adormecer } \\
\text { tranquilamente. Após alguns } \\
\text { outros transes, nos quais reviu } \\
\text { todas as suas tarefas, solicitei-Ihe } \\
\text { que recordasse, uma por uma, } \\
\text { cada tarefa, e percebesse [P - } 26 \\
\text { - Predicado de conscientização] } \\
\text { dirigidas }\end{array}$ & & \\
\hline
\end{tabular}

(continua) 
(continuação)

\begin{tabular}{|c|c|c|}
\hline NARRAÇÃO (ERICKSON) & FALA (ANN) & FALA (ERICKSON) \\
\hline $\begin{array}{l}\text { Ann tinha consultas a cada } \\
\text { quinze dias. Dentro de seis } \\
\text { meses, ela entrou, com grande } \\
\text { interesse, para explicar que não } \\
\text { conseguiria encontrar nenhuma } \\
\text { razão para pesar tanto - ou para } \\
\text { se vestir tão mal [MFS - 1 - } \\
\text { Vinculação - embora, neste } \\
\text { caso, Erickson empregue a } \\
\text { expressão "ou", fica implícito o } \\
\text { vínculo que ele estabelece entre } \\
\text { "pesar tanto" e "vestir-se mal”]. } \\
\text { Ela havia lido bastante sobre } \\
\text { cosmetologia, penteados e } \\
\text { maquilagem. Havia lido livros } \\
\text { sobre cirurgia plástica, sobre } \\
\text { ortodontia. Perguntou, } \\
\text { tristemente, se não lhe seria } \\
\text { permitido saber o que poderia } \\
\text { fazer a seu respeito. } \\
\text { Depois de um ano, estava } \\
\text { pesando sessenta e cinco quilos. } \\
\text { Seu gosto para roupas era } \\
\text { excelente, e estava num } \\
\text { emprego muito melhor. Estava se } \\
\text { inscrevendo na universidade e, } \\
\text { embora ainda pesasse sessenta e } \\
\text { três quilos, estava noiva e ia se } \\
\text { casar. Ela extraíra e substituíra } \\
\text { dois dentes que haviam crescido } \\
\text { fora de alinhamento. Seu sorriso } \\
\text { era realmente atraente. } \\
\text { Trabalhava como artista de moda } \\
\text { para catálogos e jornais. }\end{array}$ & & \\
\hline $\begin{array}{l}\text { Ann trouxe o noivo para me } \\
\text { conhecer. Ela entrou no } \\
\text { consultório primeiro e disse: }\end{array}$ & $\begin{array}{l}\text { Este maldito tolo é tão burro! } \\
\text { Ele pensa que sou bonita. E } \\
\text { eu nunca vou desiludi-lo. } \\
\text { Seus olhos brilham quando } \\
\text { olha pra mim. Mas tanto você } \\
\text { quanto eu sabemos a } \\
\text { verdade. Tenho dificuldade } \\
\text { em manter peso-e tenho } \\
\text { medo de engordar de novo. } \\
\text { Mas realmente sei que ele me } \\
\text { ama como sou }\end{array}$ & \\
\hline
\end{tabular}

(continua) 
(continuação)

\begin{tabular}{|l|l|l|}
\hline NARRAÇÃO (ERICKSON) & FALA (ANN) & FALA (ERICKSON) \\
\hline Eles estão casados há quinze & Quando você falou aquelas & \\
anos e têm três belos filhos. & coisas horrorosas a meu & \\
Ann fala livremente sobre sua & respeito, foi tão franco! Sabia & \\
terapia, pois se lembra de & que me dizia a verdade. Mas, & \\
tudo que lhe foi dito. Mais de & $\begin{array}{l}\text { se não tivesse me colocado } \\
\text { em transe, não teria feito }\end{array}$ & \\
uma vez, afirmou: & nenhuma das coisas que me & \\
& fezfazer. & \\
\hline
\end{tabular}

Quadro 3 - Caso Ann (final) 


\begin{tabular}{|c|c|c|}
\hline NARRAÇÃO (ERICKSON) & FALA (MENINO) & FALA (ERICKSON) \\
\hline $\begin{array}{l}\text { Uma mãe me procurou e contou } \\
\text { sobre o filho de dez anos que } \\
\text { molhava a cama todas as noites. } \\
\text { Eles [os pais] haviam feito tudo o } \\
\text { que era possível para que } \\
\text { parasse. Eles o arrastaram para } \\
\text { me ver - literalmente. O pai } \\
\text { segurava por uma mão, a mãe } \\
\text { pela outra, e o menino arrastava } \\
\text { os pés. Eles os [sic] deitaram com } \\
\text { o rosto para o chão no meu } \\
\text { consultório. Empurrei os pais } \\
\text { para fora e fechei a porta. O } \\
\text { menino urrava. } \\
\text { Quando parou para recuperar o } \\
\text { fôlego, eu disse: }\end{array}$ & & $\begin{array}{l}\text { Que maneira estúpida de trazer } \\
\text { você aqui! Não gosto nem um } \\
\text { pouco. }\end{array}$ \\
\hline $\begin{array}{l}\text { Ele ficou surpreso de eu ter dito } \\
\text { isto. Hesitou, enquanto tomava } \\
\text { fôlego, e eu lhe disse que podia ir } \\
\text { em frente e berrar de novo. Ele } \\
\text { deixou escapar um grito e, } \\
\text { quando fez uma pausa para } \\
\text { respirar, soltei um grito. Ele se } \\
\text { voltou e me encarou, e eu disse: }\end{array}$ & & É a minha vez. \\
\hline Então disse: & & Agora é a sua vez (...) \\
\hline $\begin{array}{l}\text { (...) e ele gritou de novo. Eu } \\
\text { gritei, e então disse que era a vez } \\
\text { dele. Sugeri: }\end{array}$ & & $\begin{array}{l}\text { Poderíamos continuar fazendo } \\
\text { turnos, mas isso seria } \\
\text { extremamente cansativo [P - } \mathbf{1 7} \\
\text { - Uso de advérbio que introduz } \\
\text { um comentário]. Na minha vez, } \\
\text { vou simplesmente me sentar [P } \\
\text { - } 17 \text { - Uso de advérbio que } \\
\text { introduz um comentário] } \\
\text { naquela cadeira. Há uma outra } \\
\text { vaga, do outro lado. [PEI - 1- } \\
\text { Ordem embutida] }\end{array}$ \\
\hline $\begin{array}{l}\text { Quando chegou a minha vez, } \\
\text { sentei-me na cadeira e ele } \\
\text { sentou-se na outra. A expectativa } \\
\text { havia sido estabelecida - eu } \\
\text { estabelecera que nos } \\
\text { revezássemos nos gritos, e mudei } \\
\text { o jogo ao propor turnos para } \\
\text { sentar. A seguir, disse: }\end{array}$ & & $\begin{array}{l}\text { Sabe, seus pais me mandaram } \\
\text { curar você do hábito de molhar } \\
\text { a cama. Quem eles pensam que } \\
\text { são para me dar ordens? [P - } 23 \\
\text { - Pergunta retórica] }\end{array}$ \\
\hline
\end{tabular}

Quadro 4 - Menino de dez anos (continua) 


\section{(continuação)}

\begin{tabular}{|c|c|c|}
\hline NARRAÇÃO (ERICKSON) & FALA (MENINO) & FALA (ERICKSON) \\
\hline $\begin{array}{l}\text { Ele havia recebido muitos } \\
\text { castigos dos pais, de modo que, } \\
\text { ao dizer isso, assinalei de que } \\
\text { lado da cerca eu estava. Disse } \\
\text { então: }\end{array}$ & & 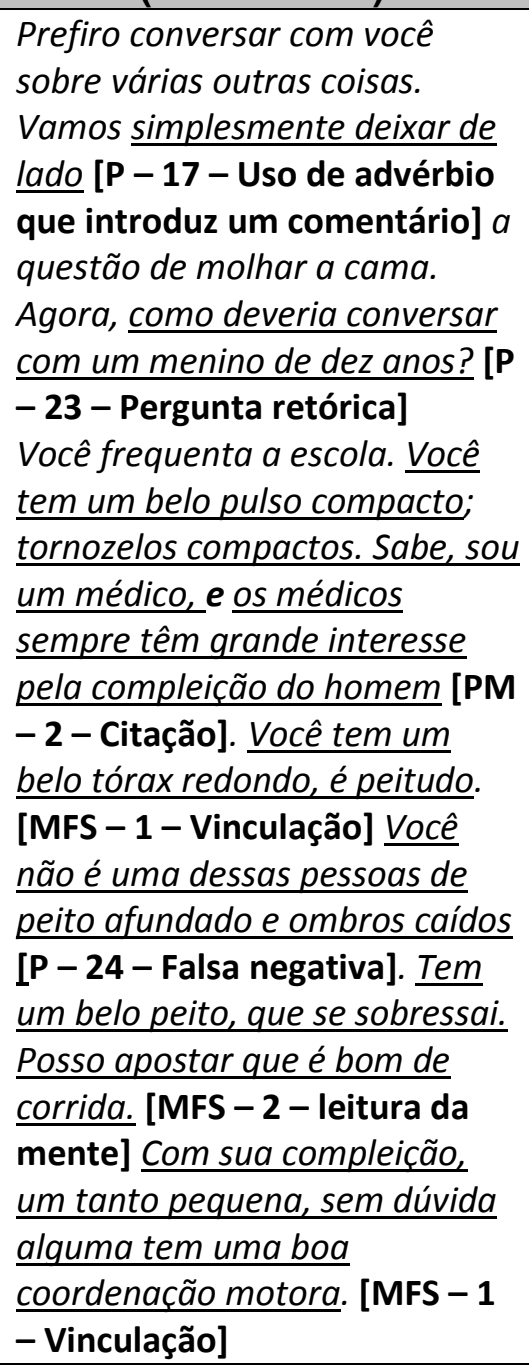 \\
\hline 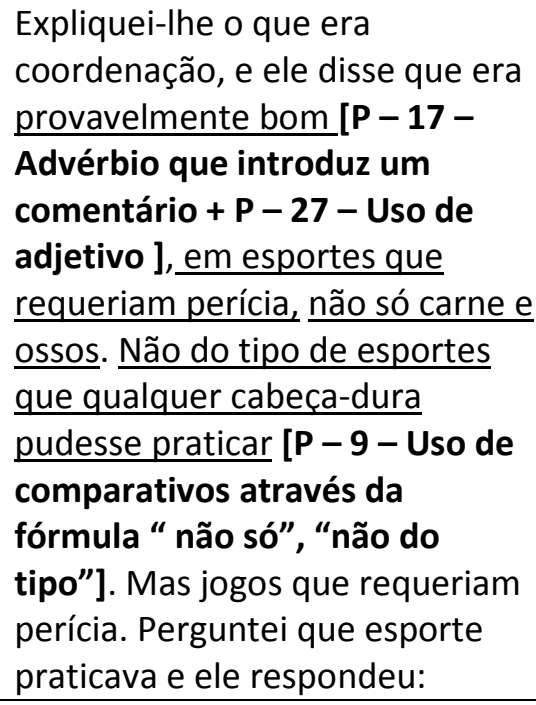 & $\begin{array}{l}\text { Jogo beisebol e atiro com } \\
\text { arco e flecha. }\end{array}$ & \\
\hline Perguntei: & & $\begin{array}{l}\text { Você é bom [P - } 27 \text { - Uso de } \\
\text { adjetivo ]com o arco? }\end{array}$ \\
\hline Ele respondeu: & Muito bom. & \\
\hline
\end{tabular}

(continua) 
(continuação)

\begin{tabular}{|c|c|c|}
\hline NARRAÇÃO (ERICKSON) & FALA (MENINO) & FALA (ERICKSON) \\
\hline Eu disse: & & $\begin{array}{l}\text { Bem, naturalmente isto requer } \\
\text { [P-17-Advérbio que introduz } \\
\text { um comentário] olhos, mãos, } \\
\text { braços e coordenaçẫo corporal. }\end{array}$ \\
\hline $\begin{array}{l}\text { Veio à tona que seu irmão mais } \\
\text { moço jogava futebol, que era } \\
\text { mais robusto do que ele [P - - - } \\
\text { Uso de comparativo]ou qualquer } \\
\text { outro membro da família }\end{array}$ & & $\begin{array}{l}\text { O futebol é um belo jogo para } \\
\text { quem é só um monte [CI - - - } \\
\text { Índice referencial não- } \\
\text { específico ]de músculos. Uma } \\
\text { porção [CI - } 3 \text { - Índice } \\
\text { referencial não-específico ]de } \\
\text { sujeitos grandes, } \\
\text { demasiadamente crescidos, [P - } \\
17 \text { - Advérbio que introduz um } \\
\text { comentário] gosta dele. }\end{array}$ \\
\hline $\begin{array}{l}\text { Assim, continuamos conversando } \\
\text { sobre isto ou aquilo [CI - 3- } \\
\text { Índice referencial não- } \\
\text { específico] e sobre a } \\
\text { coordenação muscular. Eu disse: }\end{array}$ & & $\begin{array}{l}\text { Você sabe, quando recua com } \\
\text { seu arco e mira a sua flecha, } \underline{0} \\
\text { que supõe que a pupila dos } \\
\text { olhos faça? [P - 23- Pergunta } \\
\text { retórica] Ela se fecha. }\end{array}$ \\
\hline $\begin{array}{l}\text { Expliquei que havia músculos } \\
\text { chatos, músculos curvos, } \\
\text { músculos longos - e também } \\
\text { circulares (...) }\end{array}$ & & 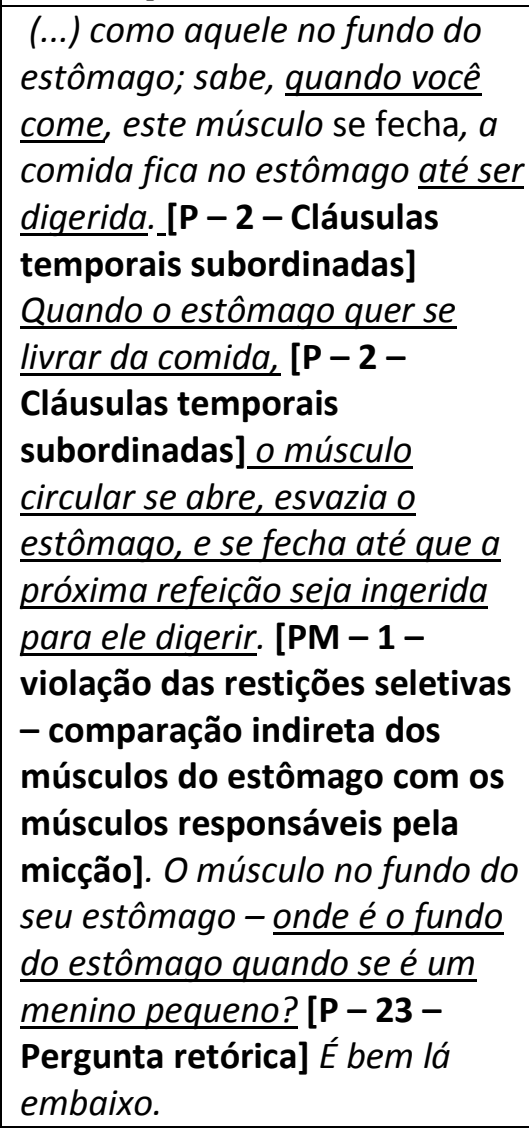 \\
\hline
\end{tabular}

(continua) 


\section{(continuação)}

\begin{tabular}{|c|c|c|}
\hline NARRAÇÃO (ERICKSON) & FALA (MENINO) & FALA (ERICKSON) \\
\hline $\begin{array}{l}\text { Assim, discutimos o assunto } \\
\text { durante uma hora e no sábado } \\
\text { seguinte ele veio me ver sozinho. } \\
\text { Conversamos um pouco mais } \\
\text { sobre esportes, sobre isto e } \\
\text { aquilo - sem nenhuma menção a } \\
\text { molhar a cama. Falamos sobre os } \\
\text { escoteiros e sobre } \\
\text { acampamentos, tudo [LMI - 1- } \\
\text { Quantificador universal ]o que } \\
\text { pudesse interessar a um menino } \\
\text { pequeno. Na quarta entrevista } \\
\text { ele apareceu com um grande } \\
\text { sorriso. Disse: }\end{array}$ & $\begin{array}{l}\text { Sabe, há anos minha mãe } \\
\text { tenta perder seu hábito. Mas } \\
\text { não consegue. }\end{array}$ & \\
\hline $\begin{array}{l}\text { A mãe fumava e estava tentando } \\
\text { parar. Eu disse: }\end{array}$ & & $\begin{array}{l}\text { É, algumas pessoas [Cl-3- } \\
\text { Índice referencial não- } \\
\text { específico] conseguem romper } \\
\text { hábitos [Cl - } 1 \text { Nominalização] } \\
\text { rapidamente [P - 17 - Advérbio } \\
\text { que introduz um comentário], } \\
\text { mas outras falam muito sobre } \\
\text { isto e não fazem nada [LMI - } 1 \\
\text { - Quantificador universal]. }\end{array}$ \\
\hline $\begin{array}{l}\text { Então mudamos a conversa para } \\
\text { outros assuntos. } \\
\text { Uns seis meses depois, ele veio } \\
\text { me visitar socialmente e voltou } \\
\text { aparecer quando entrou para o } \\
\text { segundo grau. Agora está na } \\
\text { faculdade. } \\
\text { Tudo o que eu fiz foi conversar } \\
\text { sobre os músculos circulares } \\
\text { existentes no fundo do } \\
\text { estômago, que podiam se fechar } \\
\text { e segurar os conteúdos. [PM -1- } \\
\text { Violação das restrições seletivas] } \\
\text { Linguagem simbólica, } \\
\text { naturalmente, mas toda aquela } \\
\text { bela compleição de olhos, mãos } \\
\text { e coordenação corporal deixou } \\
\text { de molhar a cama sem nunca ter } \\
\text { discutido o assunto. }\end{array}$ & & \\
\hline
\end{tabular}

Quadro 4 - Menino de dez anos (final) 


\begin{tabular}{|c|c|c|}
\hline NARRAÇÃO (ERICKSON) & FALA (PAI / MENINO) & FALA (ERICKSON) \\
\hline $\begin{array}{l}\text { Durante dois anos, um menino } \\
\text { de doze anos cutucava uma } \\
\text { ferida, uma espinha, na testa, e } \\
\text { ela havia se tornado uma } \\
\text { contínua ulceração. O pai e a } \\
\text { mãe haviam esgotado todas as } \\
\text { maneiras de punição para } \\
\text { impedi-lo de coçar a ferida. Os } \\
\text { professores e colegas de escola } \\
\text { haviam tentado reformá-lo. } \\
\text { Médicos haviam-lhe falado sobre } \\
\text { o câncer, posto bandagens e } \\
\text { tampado a ferida, e feito tudo o } \\
\text { que podiam fazer para que ele } \\
\text { não a tocasse. O menino } \\
\text { conseguia enfiar o dedo sob o } \\
\text { curativo e cutucar a ferida. } \\
\text { Explicava que não conseguia } \\
\text { controlar o impulso. } \\
\text { A mãe e o pai haviam feito o } \\
\text { possível para conseguir que o } \\
\text { menino parasse, mas } \\
\text { discordavam quanto ao valor da } \\
\text { punição. O pai chegou ao } \\
\text { extremo de privar o menino de } \\
\text { todos os brinquedos; havia } \\
\text { vendido sua bicicleta e quebrado } \\
\text { seu arco e flecha. } \\
\text { Finalmente, os pais trouxeram o } \\
\text { menino para me ver. Tive uma } \\
\text { entrevista com a mãe, para } \\
\text { descobrir alguma coisa sobre a } \\
\text { qual trabalhar. Fiquei } \\
\text { conhecendo os valores e os } \\
\text { deveres da casa, incluindo o fato } \\
\text { de que o menino era obrigado a } \\
\text { prestar pequenos serviços. } \\
\text { Cuidava do amplo gramado e do } \\
\text { jardim da casa. } \\
\text { Fiquei sabendo também que a } \\
\text { mãe tendia a ficar do lado do } \\
\text { menino, e que ele estava bravo } \\
\text { com o pai por vários castigos, em } \\
\text { particular pela quebra do seu } \\
\text { arco e flecha. }\end{array}$ & & \\
\hline
\end{tabular}

Quadro 5 - Menino de doze anos (continua) 


\section{(continuação)}

\begin{tabular}{|c|c|c|}
\hline NARRAÇÃO (ERICKSON) & FALA (PAI / MENINO) & FALA (ERICKSON) \\
\hline $\begin{array}{l}\text { Deste modo, o menino podia } \\
\text { chamar o comportamento do pai } \\
\text { de estúpido, mas, ao fazê-lo, } \\
\text { estaria também dando-lhe um } \\
\text { crédito por ser bem-intencionado. } \\
\text { Então perguntei quanto tempo } \\
\text { deveríamos discutir os } \\
\text { medicamentos que não haviam } \\
\text { funcionado. Ou podíamos } \\
\text { esquecê-los? Eu disse: }\end{array}$ & & $\begin{array}{l}\text { Você os tem tomado por dois } \\
\text { anos. [P - 26-Predicado de } \\
\text { conscientização] Todos [LME - } \\
1 \text { - Quantificadores universais] } \\
\text { os remédios, desde a quebra do } \\
\text { arco e da flecha até a venda da } \\
\text { bicicleta, [P - } \mathbf{2} \text { - Cláusulas } \\
\text { temporais subordinadas] não } \\
\text { deram certo. O que devemos } \\
\text { fazer? }[\mathbf{P}-\mathbf{2 3} \text { - Pergunta } \\
\text { retórica] }\end{array}$ \\
\hline $\begin{array}{l}\text { O menino sugeriu que eu me } \\
\text { encarregasse da questão. } \\
\text { Eu lhe disse: }\end{array}$ & & $\begin{array}{l}\text { Certo, eu me encarregarei. Mas } \\
\text { você não vai qostar [P - 24- } \\
\text { Falsa negativa] do modo como } \\
\text { vou conduzi-la. Porque vou fazer } \\
\text { algo [Cl - } \mathbf{3} \text { - Índice referencial } \\
\text { não-específico] que vai limpara } \\
\text { a úlcera. Você não vai gostar } \\
\text { nem um pouco; [P - 24 - Falsa } \\
\text { negativa] só [P - 12- } \\
\text { Qualificador] vai gostar de que } \\
\text { a úlcera sare - disso você vai } \\
\text { gostar de verdade [P - 3- Frase } \\
\text { de efeito (cleft sentence)].[PEI } \\
\text { - 6c - Ambiguidade de escopo] }\end{array}$ \\
\hline $\begin{array}{l}\text { Disse-lhe que queria que } \\
\text { dedicasse todos os fins de } \\
\text { semana à cura da ferida em sua } \\
\text { testa - enquanto o pai faria os } \\
\text { trabalhinhos de fim de semana } \\
\text { para ele. [P - 2 - Cláusula } \\
\text { temporal subordinada] O } \\
\text { menino lançou um olhar } \\
\text { triunfante para mim e para o pai. } \\
\text { Continuamos conversando sobre } \\
\text { a faina doméstica e discutimos o } \\
\text { corte da grama, como varrer o } \\
\text { gramado com o ancinho, como } \\
\text { limpara a sujeira do cachorro, } \\
\text { semear o jardim e todo o resto. } \\
\text { Perguntei quem inspecionava o } \\
\text { gramado quando o menino } \\
\text { aparava a grama. O pai } \\
\text { inspecionava o trabalho. Eu disse: }\end{array}$ & & $\begin{array}{l}\text { Bem, sábado, nos intervalos de } \\
\text { seu trabalho de curar sua } \\
\text { úlcera, [P - } \mathbf{2} \text { - Cláusula } \\
\text { temporal subordinada] porque } \\
\text { não pode trabalhar nela sem } \\
\text { parar, você pode sair e } \\
\text { inspecionar como seu pai está } \\
\text { executando as tarefas. }\end{array}$ \\
\hline
\end{tabular}

(continua) 


\section{(continuação)}

\begin{tabular}{|c|c|c|}
\hline NARRAÇÃO (ERICKSON) & FALA (PAI / MENINO) & FALA (ERICKSON) \\
\hline $\begin{array}{l}\text { Neste ponto, o menino estava } \\
\text { muito curioso a respeito do que } \\
\text { faria no fim de semana para } \\
\text { curar sua úlcera, e eu comecei o } \\
\text { procedimento de digressão. De } \\
\text { uma maneira um tanto lenta, } \\
\text { irritante, prolongada, } \\
\text { emaranhada, [P - 27 - Uso de } \\
\text { adjetivos] ofereci-lhe um plano } \\
\text { terapêutico. Quando agimos } \\
\text { assim, o paciente inclina-se a } \\
\text { desejar que cheguemos ao fim de } \\
\text { tudo aquilo - ele quer saber o } \\
\text { que, afinal, terá de fazer. Dá } \\
\text { valor ao cuidado deliberado que } \\
\text { tomamos em nossa } \\
\text { apresentação. Sabe que não } \\
\text { vamos empurrar as coisas para } \\
\text { cima dele. E fica esperando que } \\
\text { cheguemos ao que importa, e } \\
\text { quando, finalmente, o fazemos, } \\
\text { ele está motivado para aceitar o } \\
\text { plano. }\end{array}$ & & \\
\hline Disse ao menino: & & $\begin{array}{l}\text { Descobri que sua ortografia é } \\
\text { muito ruim. [P - } 27 \text { - Uso de } \\
\text { adjetivo] Sua ortografia é fraca } \\
\text { [P - } 27 \text { - Uso de adjetivo] } \\
\text { porque, quando escreve uma } \\
\text { palavra, você em geral deixa } \\
\text { letras de fora. }\end{array}$ \\
\hline Então, continuei: & & $\begin{array}{l}\text { Penso que deve [LME - 2 - } \\
\text { Operador modal de } \\
\text { necessidade] começar a curar } \\
\text { sua úlcera no sábado de manhã, } \\
\text { mais ou menos às seis horas [P } \\
-18 \text { - Cláusula contrafactual } \\
\text { com efeito condicionate]. Você } \\
\text { sabe [P - } 26 \text { - Predicado de } \\
\text { conscientização] que levará as } \\
\text { coisas muito mais a sério se se } \\
\text { levantar cedo [P - 18 - Cláusula } \\
\text { contrafactual com efeito } \\
\text { condicionate] para fazê-las, } \\
\text { porque este é um neqócio [CI - } \\
1 \text { - Nominalização] muito sério. }\end{array}$ \\
\hline
\end{tabular}

(continua) 
(continuação)

\begin{tabular}{|c|c|c|}
\hline NARRAÇÃO (ERICKSON) & FALA (PAI / MENINO) & FALA (ERICKSON) \\
\hline & & 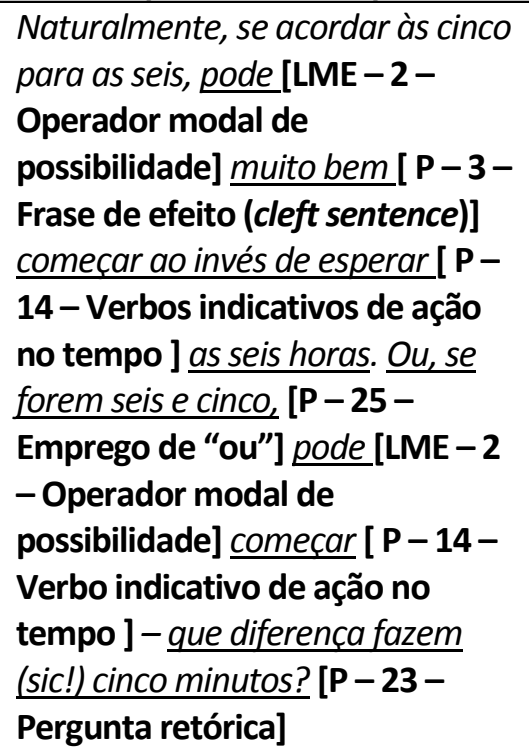 \\
\hline E prossegui: & & 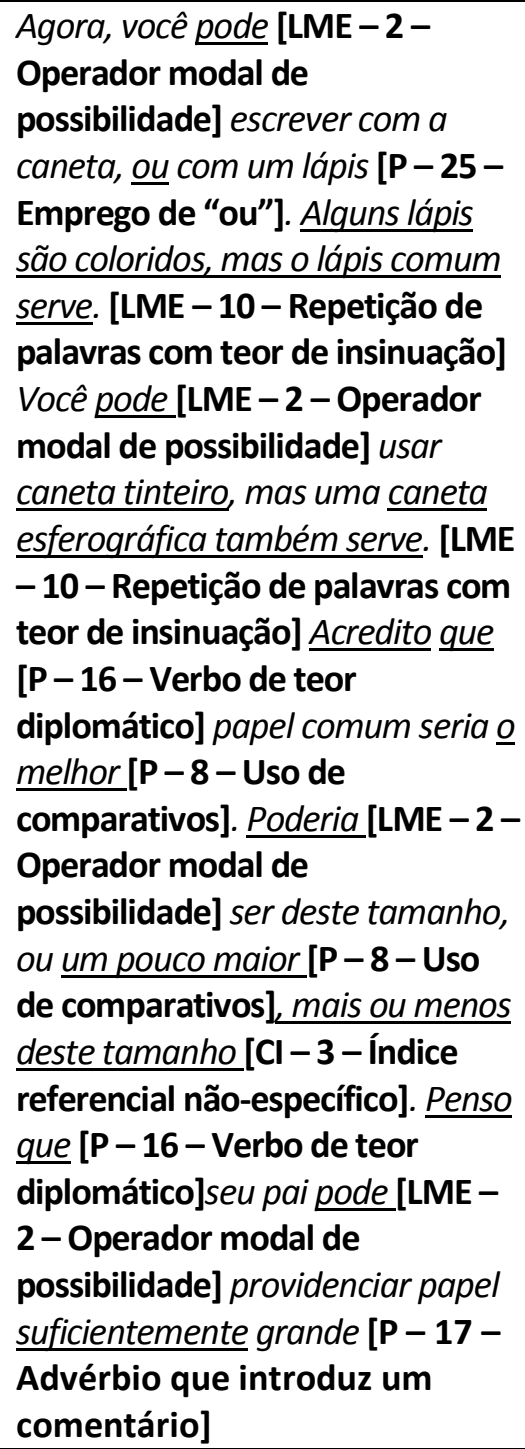 \\
\hline
\end{tabular}


(continuação)

\begin{tabular}{|c|c|c|}
\hline NARRAÇÃO (ERICKSON) & FALA (PAI / MENINO) & FALA (ERICKSON) \\
\hline $\begin{array}{l}\text { Finalmente, disse-Ihe o que ele } \\
\text { estava curioso por ouvir: }\end{array}$ & & $\begin{array}{l}\text { Esta é a frase que deve escrever: } \\
\text { 'Não acho uma boa idéia cutucar } \\
\text { a ferida em minha testa'. }\end{array}$ \\
\hline $\begin{array}{l}\text { Repeti a frase lentamente e com } \\
\text { cuidado, dizendo: }\end{array}$ & & 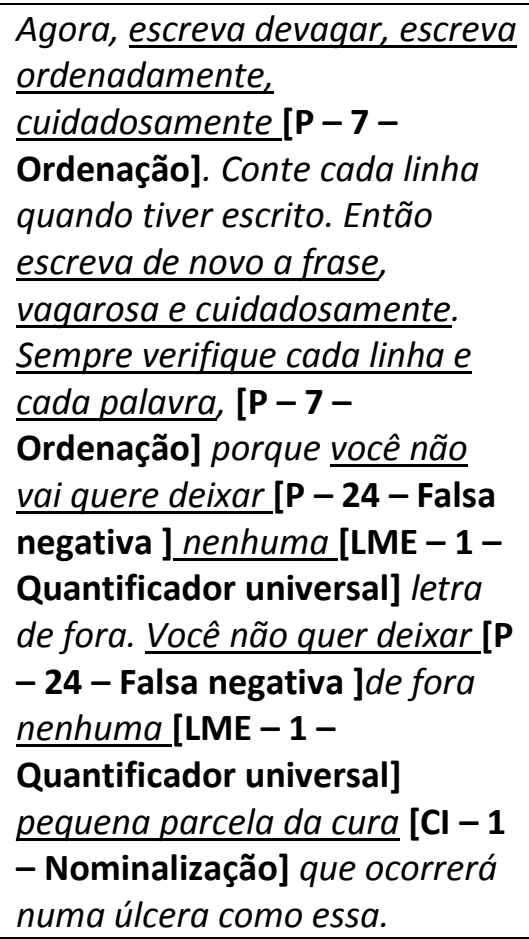 \\
\hline 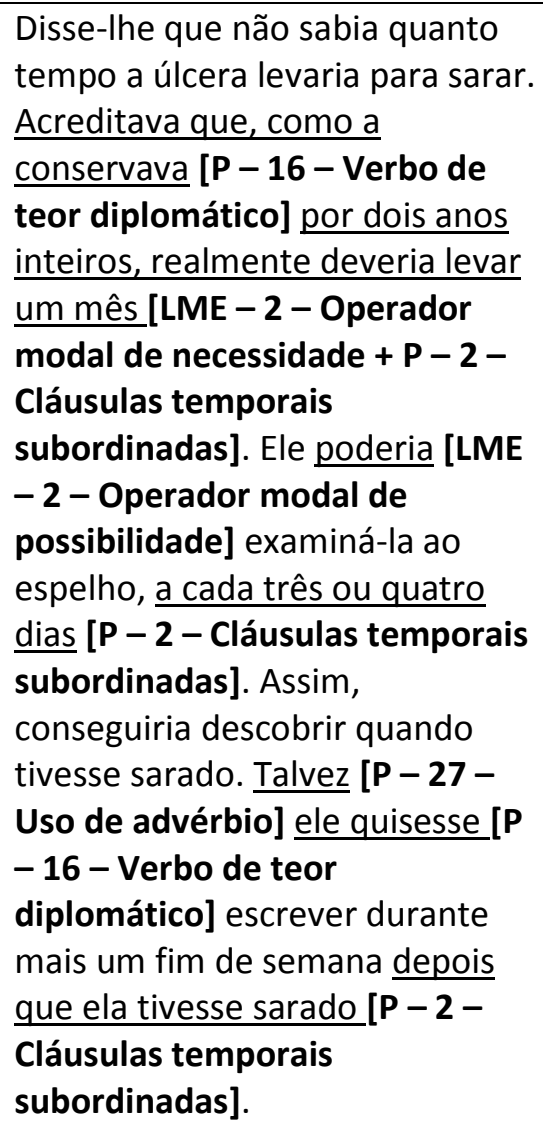 & & \\
\hline
\end{tabular}

(continua) 


\section{(continuação)}

\begin{tabular}{|c|c|c|}
\hline NARRAÇÃO (ERICKSON) & FALA (PAI / MENINO) & FALA (ERICKSON) \\
\hline 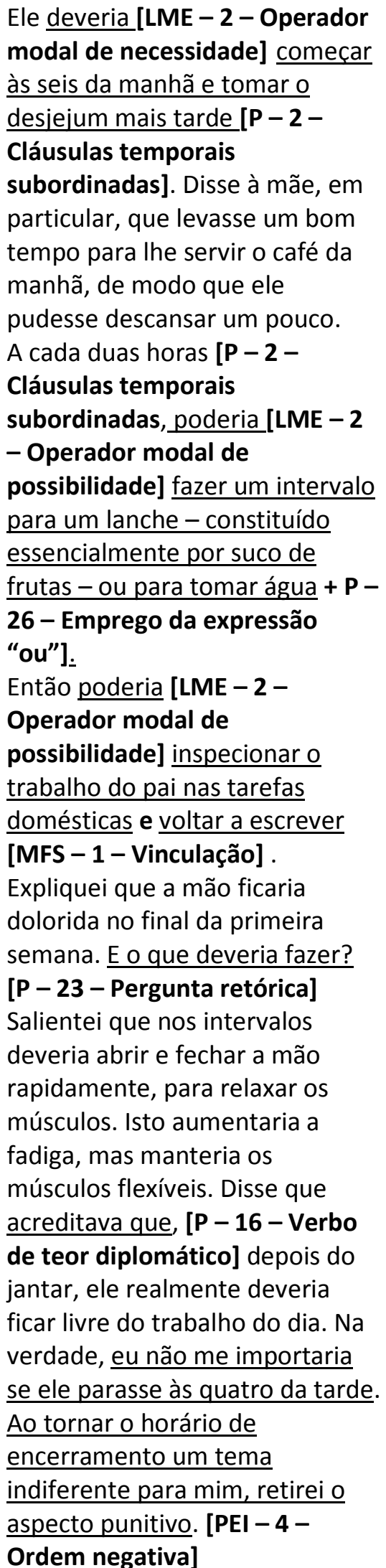 & & \\
\hline
\end{tabular}

(continua) 


\section{(continuação)}

\begin{tabular}{|c|c|c|}
\hline NARRAÇÃO (ERICKSON) & FALA (PAI / MENINO) & FALA (ERICKSON) \\
\hline $\begin{array}{l}\text { O menino escreveu o dia inteiro, } \\
\text { no sábado e no domingo; todos } \\
\text { os fins de semana. [P - } \mathbf{2}- \\
\text { Cláusulas temporais } \\
\text { subordinadas] Recebi uma } \\
\text { imensa pilha de papeis contendo } \\
\text { a frase - tudo escrito com } \\
\text { orgulho e contentamento. O pai } \\
\text { não precisava instigá-lo, e tanto } \\
\text { ele quanto a mãe estavam } \\
\text { surpresos com o orgulho que o } \\
\text { menino sentia com sua caligrafia. } \\
\text { A sentença, mil vezes escrita, foi } \\
\text { lindamente executada. Deixei } \\
\text { claro aos pais que a inspeção da } \\
\text { caligrafia era de minha } \\
\text { competência. Se ele quisesse } \\
\text { mostrar aos pais, tudo bem, mas } \\
\text { eu era o inspetor. Eu examinava } \\
\text { cada página. Disse ao menino } \\
\text { que deveria [LME - } 2 \text { - Operador } \\
\text { modal de necessidade] dar uma } \\
\text { olhada rápida, apressada, em } \\
\text { cada página, e perguntei se havia } \\
\text { alguma à qual eu deveria [LME - } \\
\mathbf{2}-\text { Operador modal de } \\
\text { necessidade] prestar mais } \\
\text { atenção. Deste modo, ele me } \\
\text { absolveu do exame rápido. } \\
\text { Quanto mais escrevia, mais } \\
\text { justificativas tinha para } \\
\text { inspecionar o trabalho do pai. } \\
\text { Quanto mais escrevia, mais } \\
\text { caprichado ficava o que escrevia. } \\
\text { [P - } 9 \text { - Uso de comparativos } \\
\text { através da fórmula "quanto } \\
\text { mais... mais"] Todos os dados } \\
\text { estavam voltados para o } \\
\text { progresso. Com este método, fiz } \\
\text { com ele (sic!) deixasse de cutucar } \\
\text { compulsivamente a ferida e o } \\
\text { obriguei a escrever } \\
\text { compulsivamente, com capricho, } \\
\text { algo do que poderia ter um } \\
\text { enorme orgulho. }\end{array}$ & & \\
\hline
\end{tabular}

(continua) 
(continuação)

\begin{tabular}{|c|c|c|}
\hline NARRAÇÃO (ERICKSON) & FALA (PAI / MENINO) & FALA (ERICKSON) \\
\hline O pai comentou: & $\begin{array}{l}\text { Pai - Eu sabia o que tinha } \\
\text { que fazer. Fiz um belo } \\
\text { trabalho naquele gramado. }\end{array}$ & \\
\hline $\begin{array}{l}\text { Num mês a úlcera estava curada. } \\
\text { Um ano mais tarde, não havia } \\
\text { voltado. Daquela úlcera crônica, } \\
\text { indolente, horrível, não havia } \\
\text { nem mesmo uma cicatriz. } \\
\text { Coloquei a pilha de papel escrita } \\
\text { pelo menino no meu arquivo e } \\
\text { perguntei-Ihe por quanto tempo } \\
\text { deveria guardá-la. Enchia } \\
\text { completamente um arquivo. Ele } \\
\text { respondeu que acreditava que eu } \\
\text { gostaria de guardá-la durante } \\
\text { alguns meses [P - } \mathbf{1 6 - V e r b o ~ d e ~} \\
\text { teor diplomático]. Perguntei-lhe } \\
\text { o que deveria fazer depois. Ele } \\
\text { respondeu: }\end{array}$ & $\begin{array}{l}\text { Menino - Ah, a esta altura } \\
\text { será somente um monte de } \\
\text { papel usado. }\end{array}$ & \\
\hline
\end{tabular}

Quadro 5 - Menino de doze anos (final) 


\subsection{Análise dos casos selecionados: leitura horizontal}

Nesta seção, é apresentada a segunda parte da metodologia, a leitura horizontal. Os trechos assinalados no quadro da leitura vertical foram compilados na leitura horizontal de acordo com as categorias e subcategorias do Metamodelo e do Modelo Milton, visando oferecer uma visão mais ampla dos efeitos destas no discurso ericksoniano, identificados em cada um dos três casos selecionados - "Ann", "Menino de dez anos" e "Menino de doze anos" - e comentados na sequência.

\subsubsection{Ocorrências referentes à primeira categoria do Metamodelo}

Diferentemente do efeito provocado no Metamodelo, em que a categoria Coleta de Informações busca promover uma descrição mais completa e precisa da experiência do emissor (cliente), no Modelo Milton as informações são lançadas pelo terapeuta de maneira a oferecer ao cliente informações sucintas, visando impedir questionamentos de sua parte. As "soluções" apontadas pelo terapeuta devem ser acatadas como "eficazes", de modo que as tarefas, quando propostas, não precisam, necessariamente, ser compreendidas em relação ao seu sentido e aos efeitos que proporcionarão ao cliente - é suficiente que sejam entendidas para que possam ser executadas.

A categoria Coleta de Informações compreende três subcategorias Nominalizações, Verbos não-específicos e Índices referenciais não-específicos - verificadas a seguir nos casos selecionados.

Erickson se vale de nominalizações, mediante as quais cada cliente possa thes atribuir o significado que deseje para compor o sentido da frase/ação. Às vezes, é conveniente ao cliente que simplesmente pareça entender o significado implícito na nominalização para entrar em rapport com Erickson, consequentemente, executar a tarefa "salvadora" que the é designada por este.

Algumas nominalizações empregadas por Erickson: 
Ann

- Você realmente não contou a verdade

- Conhece alguns fatos da vida

- Para ser curto e grosso: você é uma confusão medonha

- Penso que sabe que não hesitarei em dizer a verdade

- Você precisa saber a verdade a seu respeito antes mesmo de poder aprender coisas necessárias para se ajudar

- Será uma oportunidade para eu lhe dizer algumas outras coisas descorteses

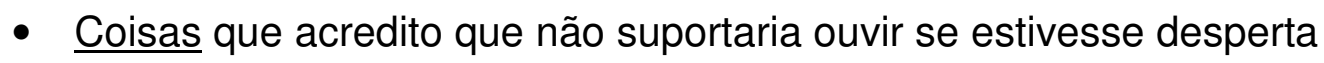

- Não perca tempo, assim como não perde tempo em fazer de si mesma uma coisa repulsiva de se olhar

- Há muitas verdades que quero lhe dizer

- Seja apenas um autômato impotente

- Balance a cabeça e faça exatamente o que the ordeno, porque sabe que lhe direi a verdade

- Selvagens primitivos se casarão com coisas que têm uma aparência pior do que a sua

- Ordenei a ela que se dirigisse para a área mais movimentada da cidade (em estado desperto) e observasse as formas peculiares e as faces das coisas com que os homens se casam

- Na semana seguinte, deveria olhar formas e faces peculiares das coisas com que as mulheres se casam, e se assombrar com isto

- Disse-lhe que estava começando a aprender alguma coisa.

- Então disse-lhe que voltasse à biblioteca e se dedicasse aos livros que tratavam e costumes humanos, vestuário e aparência - para descobrir alguma coisa 


\section{Menino de 10 anos}

- É, algumas pessoas conseguem romper hábitos rapidamente, mas outras falam muito sobre isto e não fazem nada

\section{Menino de 12 anos}

- Você sabe que levará as coisas muito mais a sério se se levantar cedo para fazê-las, porque este é um negócio muito sério

- Você não quer deixar de fora nenhuma pequena parcela da cura que ocorrerá numa úlcera como essa

Note-se que a palavra "coisa" é empregada inúmeras vezes, com teor totalmente subjetivo, pois não carrega em si nenhum traço de especificidade. Igualmente o conceito "a verdade" é lançado sobre o cliente com o peso de algo extremamente significativo, do qual Erickson parece ser o "dono" enquanto, ao cliente, o significado constitui um mistério.

Nos exemplos destacados, Erickson não deixa claro quais as "coisas" que precisam ser aprendidas ou constituirão algum tipo de ajuda ou, especificamente, deverão ser resgatadas pela pesquisa iconográfica de Ann. Também não explica ao menino que "hábitos" podem ser rompidos rapidamente. Permite que seus clientes preencham os claros desses subentendidos, como se fossem pressupostos compartilhados por ambos, por meio de um espelhamento eficaz Estabelece, por meio do rapport, um forte laço de cumplicidade com os mesmos - como se ambos, terapeuta e cliente, compartilhassem de um repertório comum e inequívoco, principalmente no tocante às emoções.

Erickson também se vale do uso de verbos não-específicos, que sugerem uma possível ação sem determiná-la de fato: 
Ann

- Você precisa saber a verdade a seu respeito antes mesmo de poder aprender coisas necessárias para se ajudar

- Mas não pense que não pode aguentar.

Erickson deixa em suspenso a ação efetiva que determinaria como Ann poderia/iria "se ajudar".

Igualmente não explica "O quê?", "Como?", "Quanto?" Ann precisaria aguentar. Nada disso é descrito na ação subsequente, mas o terapeuta afirma que ela é capaz de "aguentar", usando ainda o recurso da dupla negação "não pense que não pode" - "negação negada" = afirmação.

Aqui também, sendo "artisticamente vago", reforça as competências de sua cliente, afirmando que Ann será capaz de "se ajudar" e de "aguentar" - ela que, à primeira vista, era pura fragilidade e incapacidade de autogerir a própria vida.

Quanto ao uso de índice referencial não-específico por Erickson, vários exemplos foram localizados:

Ann

- Conhece alguns fatos da vida

- Será uma oportunidade para eu lhe dizer algumas outras coisas descorteses

- Pode compreender. Fazer algo

- ... o fato de você ter devorado os alimentos para ficar parecendo um balde de lixo cheio demais demonstra que precisa aprender algo

- Olhe um livro atrás do outro e fique curiosa

- Disse-lhe que estava começando a aprender alguma coisa

- ...disse-Ihe que voltasse à biblioteca e se dedicasse aos livros que tratavam e costumes humanos, vestuário e aparência - para descobrir alguma coisa retratada que tivesse, no mínimo, quinhentos anos e ainda fosse bonita 


\section{Menino de 10 anos}

- O futebol é um belo jogo para quem é só um monte de músculos. Uma porção de sujeitos grandes, demasiadamente crescidos, gosta dele

- Assim, continuamos conversando sobre isto ou aquilo e sobre a coordenação muscular

- É algumas pessoas conseguem romper hábitos rapidamente, mas outras falam muito sobre isto e não fazem nada

\section{Menino de 12 anos}

- Porque vou fazer algo que vai limpar a úlcera

- Poderia ser deste tamanho, ou um pouco maior, mais ou menos deste tamanho

- Ah, a esta altura será somente um monte de papel usado

O uso de expressões como "algo", "alguma coisa", "um monte de", "uma porção" permite ao cliente substitui-las por qualquer resultado que vislumbrem alcançar durante a terapia. Este recurso, como os das duas subcategorias anteriores, foi empregado por Erickson na contramão do uso indicado pelo Metamodelo, conforme apontam Bandler e Grinder: em vez de oferecer ao cliente opções para a ampliação de seu modelo de mundo, o terapeuta se apoia na ausência de especificidade das palavras escolhidas como quem põe um ponto final à discussão, evitando questionamentos, já que vários significados podem ser abstraídos a partir do caráter inespecífico que o enunciado adquire.

\subsubsection{Ocorrências referentes à segunda categoria do Metamodelo}

Na segunda categoria do Metamodelo, Má-formação semântica, destacam-se as subcategorias Modelo causal/vinculação, Leitura da mente e Performativo ausente. 
Erickson emprega o Modelo causal ou vinculação fazendo uso de conjunção/expressão aditiva para conectar fenômenos/ações não relacionados:

Ann

- Vou falar claramente de modo que ficará sabendo como realmente é e compreenderá que conheço você

- Você é suficientemente inteligente para ter se graduado no segundo grau, e $\underline{\text { talvez seja inteligente o suficiente para aprender a entrar no estado hipnótico }}$

- Agora que sabe que posso lhe dizer a verdade, feche os olhos e entre em transe profundo

- $\quad$ Não perca tempo, assim como não perde tempo em fazer de si mesma uma coisa repulsiva de se olhar.

- ... que não conseguiria encontrar nenhuma razão para pesar tanto - ou para se vestir tão mal (embora, neste caso, Erickson empregue a expressão "ou", fica implícito o vínculo que ele estabelece entre "pesar tanto" e "vestir-se mal")

\section{Menino de 10 anos}

- Sabe, sou um médico, e os médicos sempre têm grande interesse pela compleição do homem.

- Com sua compleição, um tanto pequena, sem dúvida alguma tem uma boa coordenação motora.

\section{Menino de 12 anos}

- Então poderia inspecionar o trabalho do pai nas tarefas domésticas e voltar a escrever

Desta maneira, Erickson desafia as estruturas lógicas construídas pela língua em torno da causalidade - o conhecido modelo causa/efeito. - uma vez que os fenômenos/ações apresentados na primeira proposição não têm relação direta com 
a que é sugerida logo após (ex.: não há ume relação de cusalidade lógica entre "ter cursado o segundo grau" e "aprender a entrar no estado hipnótico".

Diferentemente do que sugere o Metamodelo, aqui também o terapeuta apresenta seus argumentos de modo irrefutável, confundindo o cliente quanto à relação causal que estabelece, gerando um efeito hipnótico. Nenhuma derivação se apresenta no diálogo com o cliente, que aceita o vínculo como possível, acatando prontamente as sugestões de Erickson.

A Leitura da mente se apresenta em dois dos casos estudados nas intervenções de Erickson:

Ann

- Ela interpretaria mal qualquer amabilidade e não conseguiria acreditar na linguagem cortês

\section{Menino de 10 anos}

- Posso apostar que é bom de corrida.

A leitura da mente reforça o rapport estabelecido entre Erickson e seu cliente à medida que permite a este último supor que o terapeuta "sabe perfeitamente" o que ele pensa e como se sente, colocando também um ponto final a questionamentos por parte do mesmo, diferentemente dos desafios sugeridos pelo Metamodelo ante este tipo de construção frasal.

A terceira subcategoria é o Performativo ausente evidenciado nos seguintes casos amostrais:

\section{Menino de 10 anos}

- Ele disse que era provavelmente bom

- Você é bom com o arco? 


\section{Menino de 12 anos}

- Acredito que papel comum seria o melhor.

Nesses casos, Erickson não deixa claro "bom em relação a quê?", "melhor por quê?" ou "melhor em relação a quê?". Tais colocações, no entanto, reforçam sua "sabedoria" no jogo de poder que se estabelece durante a consulta terapêutica, fortalecendo o rapport entre ambos, baseado na confiança que o cliente deposita no terapeuta: Erickson sabe o que é "bom" ou "melhor" para o cliente. Assim, é sua escala de valores do terapeuta que vigora na relação.

\subsubsection{Ocorrências referentes à terceira categoria do Metamodelo}

A terceira categoria do Metamodelo, Limites do modelo do emissor, apresenta, como subcategorias, Quantificadores universais (de inclusão e exclusão) e Operadores Modais (de necessidade e de possibilidade). Foram encontradas as seguintes ocorrências desta categoria nos casos estudados:

\section{Quantificadores universais}

\section{Menino de 10 anos}

- Falamos sobre os escoteiros e sobre acampamentos, tudo o que pudesse interessar a um menino pequeno.

- É algumas pessoas conseguem romper hábitos rapidamente, mas outras falam muito sobre isto e não fazem nada

\section{Menino de 12 anos}

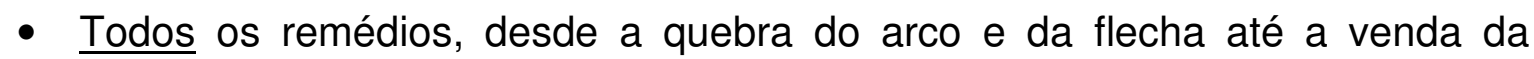
bicicleta, não deram certo

- Sempre verifique cada linha e cada palavra, porque você não vai querer deixar nenhuma letra de fora. 
- Você não quer deixar de fora nenhuma pequena parcela da cura que ocorrerá numa úlcera como essa

Aqui também, contrariando as expectativas do Metamodelo, Erickson emprega os quantificadores de modo reducionista e generalista. É claro que, no caso do menino de 12 anos, nem "todos" os remédios haviam sido experimentados, mas, apoiado nessa afirmação, o terapeuta propõe um "remédio" incomum - uma mudança de hábito, que substitui "coçar" por "escrever" compulsivamente. À medida que outros benefícios vão sendo destacados - como o aprimoramento da grafia e melhora na ortografia - o novo hábito torna-se prazeroso, não mais compulsivo. Enquanto isso, a ferida, deixada de lado, encontrou seu tempo para a cicatrização. "Nenhuma pequena parcela da cura" proposta por Erickson foi ignorada - e foi esta que, realmente, vingou.

Operadores modais também se apresentam constantemente no discurso ercksoniano. Alguns destaques de Operadores modais de necessidade empregados por Erickson:

\section{Ann}

- Você precisa saber a verdade a seu respeito antes mesmo de poder aprender coisas necessárias para se ajudar

- Mas precisa mesmo de ajuda

- [...] o fato de você ter devorado os alimentos para ficar parecendo um balde de lixo cheio demais demonstra que precisa aprender algo

- Ela deveria fazer isto durante uma semana

- Na semana seguinte, deveria olhar formas e faces peculiares das coisas com que as mulheres se casam

\section{Menino de 12 anos}

- Penso que deve começar a curar sua úlcera no sábado de manhã, mais ou menos às seis horas 
- Acreditava que, como a conservava por dois anos inteiros, realmente deveria levar um mês.

- Ele deveria começar às seis da manhã e tomar o desjejum mais tarde

- Disse ao menino que deveria dar uma olhada rápida, apressada, em cada página, e perguntei se havia alguma à qual eu deveria prestar mais atenção

O operador modal de necessidade simboliza o jogo de forças inerente ao poder: "manda quem pode, obedece quem tem juízo". Assim, Erickson se vale de sua autoridade no papel de terapeuta, instituindo o que deve ser feito. O cliente entra no jogo sabendo que precisa fazer a sua parte para alcançar o resultado desejado ao final do tratamento.

Nesse jogo de poder instituído no cenário do atendimento terapêutico, Erickson, por vezes, parece amenizar o tom autoritário acenando para o cliente com certas "possibilidades" mediante o uso dos Operadores modais de possibilidade, presentes nos casos como destacado a seguir:

Ann

- Você precisa saber a verdade a seu respeito antes mesmo de poder aprender coisas necessárias para se ajudar

- Pode compreender. Fazer algo

- Agora que sabe que posso the dizer a verdade, feche os olhos e entre em transe profundo

\section{Menino de 12 anos}

- Naturalmente, se acordar às cinco para as seis, pode muito bem começar ao invés de esperar as seis horas

- Agora, você pode escrever com a caneta, ou com um lápis

- Você pode usar caneta tinteiro, mas uma caneta esferográfica também serve

- Poderia ser deste tamanho, ou um pouco maior, mais ou menos deste tamanho 
- Ele poderia examiná-la ao espelho, a cada três ou quatro dias

- A cada duas horas, poderia fazer um intervalo para um lanche - constituído essencialmente por um suco de frutas - ou para tomar água

- Então poderia inspecionar o trabalho do pai nas tarefas domésticas e voltar a escrever

- Penso que seu pai pode providenciar papel suficientemente grande

Aqui também, diferentemente do proposto pelo Metamodelo em que a manipulação se dá por meio de declarações de impossibilidade ("não posso", "não consigo", "é impossível") - estas sim, devendo ser debeladas pelo processo de derivação Erickson apresenta a seus clientes as tarefas que Ihes atribui como "possibilidades" que amenizam seu autoritarismo.

Como demonstrado através dos exemplos destacados, as categorias e subcategorias do Metamodelo são, realmente, exploradas por Erickson em suas sessões terapêuticas, na direção contrária da derivação. Ao usá-las "artisticamente", Erickson promove o efeito por ele desejado nos atendimentos: envolver o cliente de modo a fazê-lo aderir às suas recomendações, sem maiores questionamentos.

Após explorar o Metamodelo, a seguir serão apontadas as ocorrências dos padrões relacionados às categorias e subcategorias do Modelo Milton.

\subsubsection{Ocorrências referentes à primeira categoria do Modelo Milton}

A primeira categoria proposta por Bandler e Grinder para o Modelo Milton é a das Pressuposições. Dentre as pressuposições simples, foi encontrada a seguinte subcategoria nos casos estudados: 


\section{Nomes genéricos}

Ann

- Selvagens primitivos se casarão com coisas que têm uma aparência pior do que a sua

Nesta subcategoria, um nome genérico representa toda uma classe. No exemplo anterior, Erickson recorre aos "selvagens primitivos" para demonstrar a Ann outros sensos estéticos, afirmando que alguns povos promovem casamentos entre pessoas ainda mais feias que a própria Ann. A generalização amplifica o efeito da ação "para todo um povo", minimizando o problema de Ann.

As demais subcategorias das pressuposições simples oferecem mais difícil identificação, por isso foram omitidas aqui.

Quanto às pressuposições complexas foram identificadas nas seguintes subcategorias:

\section{2 - Cláusula temporal subordinada}

Ann

- Você precisa saber a verdade a seu respeito antes mesmo de poder aprender coisas necessárias para se ajudar

\section{Menino de 10 anos}

- [...] quando você come, este músculo se fecha, a comida fica no estômago até ser digerida. Quando o estômago quer se livrar da comida, o músculo circular se abre, esvazia o estômago, e se fecha até que a próxima refeição seja ingerida para ele digerir

\section{Menino de 12 anos}

- Todos os remédios, desde a quebra do arco e da flecha até a venda da bicicleta, não deram certo 
- Disse-lhe que queria que dedicasse todos os fins de semana à cura da ferida em sua testa - enquanto o pai faria os trabalhinhos de fim de semana para ele

- Bem, sábado, nos intervalos de seu trabalho de curar sua úlcera, porque não pode trabalhar nela sem parar, você pode sair e inspecionar como seu pai está executando as tarefas

- Acreditava que, como a conservava por dois anos inteiros, realmente deveria levar um mês

- Ele poderia examiná-la ao espelho, a cada três ou quatro dias

- Talvez ele quisesse escrever durante mais um fim de semana depois que ela tivesse sarado

- Ele deveria começar às seis da manhã e tomar o desjejum mais tarde

- A cada duas horas, poderia fazer um intervalo para um lanche - constituído essencialmente por um suco de frutas - ou para tomar água

- O menino escreveu o dia inteiro, no sábado e no domingo; todos os fins de semana

Empregando advérbios temporais como "antes", "quando", "durante" e organizando ações no tempo, Erickson consegue subordinar tais ações, de modo a criar uma agenda de procedimentos para o cliente - "a cada duas horas", "a cada três ou quatro dias" - ou gerar a sensação de simultaneidade - o menino, por exemplo, deveria cuidar da ferida "enquanto" o pai cuidaria do jardim; o músculo do estômago se fecha "quando" este quer se livrar da comida. Desta forma, o terapeuta organiza as ações e os pensamentos do cliente, que segue a agenda por ele estabelecida, acreditando firmemente que os resultados surgirão no tempo previsto.

\section{3 - Frase de efeito (Cleft sentence)}

\section{Menino de 12 anos}

- Naturalmente, se acordar às cinco para as seis, pode muito bem começar ao invés de esperar as seis horas 
O recurso aparece aqui como uma maneira de enfatizar os "ganhos" do menino, motivando-o a seguir suas recomendações.

\section{7 - Ordenação}

Ann

- A primeira coisa que farei é fazer com que - ou melhor, ordenar a você conte certos fatos a seu respeito

- Ela deveria fazer isto durante uma semana. Na semana seguinte, deveria olhar formas e faces peculiares das coisas com que as mulheres se casam, e se assombrar com isto.

\section{Menino de doze anos}

- Agora, escreva devagar, escreva ordenadamente, cuidadosamente

- Conte cada linha quando tiver escrito. Então escreva de novo a frase, vagarosa e cuidadosamente. Sempre verifique cada linha e cada palavra

Embora nem sempre os numerais estejam presentes na fala de Erickson, é notável sua capacidade de construir sequências de ações numa determinada ordem, com a finalidade de organizá-las para o cliente. Assim organizadas, tal como um pai ou educador atencioso, o terapeuta reforça os laços de confiança no rapport com seu cliente.

\section{8 - Uso de comparativos}

Ann

- Então leia livros que narrem como mulheres e homens se desfiguram, fazem tatuagens, se mutilam para parecerem ainda mais horrorosos

\section{Menino de 12 anos}

- Poderia ser deste tamanho, ou um pouco maior, mais ou menos deste tamanho 
9 - Uso de comparativos através das fórmulas "não só", "não do tipo", "quanto mais... mais"

\section{Menino de dez anos}

- Expliquei-Ihe o que era coordenação, e ele disse que era provavelmente bom em esportes que requeriam perícia, não só carne e ossos. Não do tipo de esportes que qualquer cabeça-dura pudesse praticar.

\section{Menino de 12 anos}

- Quanto mais escrevia, mais justificativas tinha para inspecionar o trabalho do pai. Quanto mais escrevia, mais caprichado ficava o que escrevia

As comparações apresentadas nas subcategorias 8 e 9 são empregadas por Erickson de maneira a contextualizar uma situação ou o próprio cliente no cenário desenhado pelo terapeuta. Parece ter efeito esclarecedor, mas também aponta o lugar exato do cliente na narrativa criada por Erickson. Novamente, a liderança do terapeuta frente ao cliente é consolidada por esta estratégia.

\section{0 - Palavra com valor de insinuação}

Ann

- Nem mesmo seu cabelo está penteado decentemente

- Você não tem gosto nem para se vestir

\section{Menino de 12 anos}

- Você pode usar caneta tinteiro, mas uma caneta esferográfica também serve

As insinuações que contém a expressão "nem mesmo" são empregadas por Erickson na forma de provocação, em geral exagerando uma característica negativa. 
Com isso, o terapeuta desperta o cliente para uma possível autoanálise crítica. Já o uso da palavra "também" sugere mais opções, ao mesmo tempo que reforça a confiança do cliente em relação ao terapeuta, estreitando o rapport que se estabelece entre ambos.

\section{2 - Qualificador}

Ann

- Não faça nada, a não ser o que lhe digo para fazer

\section{Menino de 12 anos}

- Você não vai gostar nem um pouco; só vai gostar de que (sic!) a úlcera sare disso você vai gostar de verdade

O uso de qualificadores, como nos exemplos apresentados, gera um desconforto baseado numa construção de contradição, que confunde o cliente, gerando efeito hipnótico imediato. Isto permite que o terapeuta enfatize a parte mais conveniente para mobilizar o cliente - nestes casos, "fazer exatamente o que o terapeuta diz que deve ser feito" ou "gostar que a úlcera sare".

\section{4 - Inclusão de verbo/advérbio indicativo de ação temporal}

\section{Menino de 12 anos}

- Naturalmente, se acordar às cinco para as seis, pode muito bem começar ao invés de esperar as seis horas

Aqui os verbos relacionados ao tempo ajudam a organizar as ações do cliente, reforçando o direcionamento ostensivo do terapeuta, bem próprio da terapia estratégica.

\section{6 - Verbo de teor diplomático}

Ann

- Penso que sabe que não hesitarei em dizer a verdade. 
- Coisas que acredito que não suportaria ouvir se estivesse desperta

\section{Menino de 12 anos}

- Acredito que papel comum seria o melhor.

- Penso que seu pai pode providenciar papel suficientemente grande

- Acreditava que, como a conservava por dois anos inteiros, realmente deveria levar um mês.

- Talvez ele quisesse escrever durante mais um fim de semana depois que ela tivesse sarado

- Disse que acreditava que, depois do jantar, ele realmente deveria ficar livre do trabalho do dia

- Ele respondeu que acreditava que eu gostaria de guardá-la durante alguns meses

Apesar de fazer uso, muitas vezes, de palavras ásperas, na tentativa de exagerar os problemas apresentados por seus clientes, Erickson sabia também mostrar-se polido em algumas situações, a fim de estabelecer rapport com seus clientes, apelando para um modelo mais diplomático, capaz de amenizar seu tom característico de "dono da verdade". "Pensar que", "acreditar que" são colocações mais amenas do que "saber" e parecem oferecer ao cliente o beneplácito da dúvida. No entanto, como se pode ver na leitura vertical dos mesmos trechos anteriormente assinalados, tal "diplomacia" era apenas mais um recurso para envolver o cliente: os passos seguintes engendrados por Erickson apontavam sempre numa inequívoca direção.

\section{7 - Uso de advérbio que introduz um comentário}

Ann

- Você realmente não contou a verdade.

- Vou falar claramente de modo que ficará sabendo como realmente é

- Então acreditará, realmente acreditará 
- Você é o barril de gordura mais gordo, sem graça, repulsivamente horrendo que já vi

- Seu rosto é insignificantemente disperso

- Sua testa é chocantemente baixa

- Você é suficientemente inteligente para ter se graduado no segundo grau

- [‥] você está numa situação horrivelmente desvantajosa

- Entre completamente num profundo transe hipnótico

\section{Menino de 10 anos}

- Poderíamos continuar fazendo turnos, mas isso seria extremamente cansativo

- Na minha vez, vou simplesmente me sentar naquela cadeira.

- Vamos simplesmente deixar de lado a questão de molhar a cama

- Ele disse que era provavelmente bom

- Bem, naturalmente isto requer olhos, mãos, braços e coordenação corporal

- Uma porção de sujeitos grandes, demasiadamente crescidos, gosta dele

- É algumas pessoas conseguem romper hábitos rapidamente, mas outras falam muito sobre isto e não fazem nada

\section{Menino de 12 anos}

- Penso que seu pai pode providenciar papel suficientemente grande

O uso de advérbios, especialmente os de modo, é bastante explorado por Erickson e é possível averiguar seu efeito "potencializador" ou "amenizador" em relação às afirmações que os sucedem. Dizer que alguém é "repulsivamente horrendo" ou que está numa situação "horrivelmente desvantajosa" torna o horror ainda mais desagradável e a desvantagem ainda mais penosa, exagerando o grau de impotência do cliente frente ao próprio problema. Já quando o terapeuta afirma "vou simplesmente me sentar naquela cadeira", confere leveza à atitude, tornando o ato 
prosaico, corriqueiro, banal. Erickson promove efeitos hipnóticos com o uso comum de tais advérbios, à medida que os aplica associados a um adjetivo, ativando as escalas de exagero ou de contenção que subvertem o sentido original que as frases teriam, caso não fossem empregados.

\section{P - 18 - Cláusula contrafactual com efeito condicionante Menino de 12 anos}

- Penso que deve começar a curar sua úlcera no sábado de manhã, mais ou menos às seis horas. Você sabe que levará as coisas muito mais a sério se se levantar cedo para fazê-las, porque este é um negócio muito sério

Aqui Erickson atribui um dia e horário aleatoriamente para que a "cura" comece a acontecer. Apesar do caráter aleatório de sua solicitação, condiciona o ato de "levar a cura a sério" ao de "se levantar (ainda) mais cedo" - quanto mais cedo levantar, mais cedo o menino há de se curar. Os fatos não encontram relação na realidade, mas o terapeuta os vincula como se um fosse condição necessária para a realização do outro.

\section{P - 19 - Flexão de verbo em tempo futuro que contrarie a ação presente}

\section{Ann}

- [...] querer saber como seria sua aparência se pesasse somente sessenta quilos e se vestisse de modo apropriado

- [...] por que ela, que deveria ter nascido com menos de três quilos, teria adquirido aquela enorme quantidade de gordura? Por que havia se enrolado em gordura?

Incitar o cliente a imaginar uma ação futura, mesmo contrariando a realidade presente, também era recurso empregado por Erickson em seus atendimentos. Um exercício de imaginação capaz de induzir estados hipnóticos.

\section{P - 21 - Perguntas que admitem uma resposta direta}


Ann

- Qual é sua altura e seu peso?

- $\quad$ Por que veio me ver?

Essa categoria pressupõe que o cliente sabe a resposta para a pergunta formulada pelo terapeuta. É um postulado de conversação que facilita o rapport, uma introdução, um "começo de conversa".

\section{P- 23 - Pergunta retórica}

Ann

- $\quad$ Por que ela, que deveria ter nascido com menos de três quilos, teria adquirido aquela enorme quantidade de gordura? Por que havia se enrolado em gordura?

\section{Menino de 10 anos}

- Quem eles pensam que são para me dar ordens?

- Agora, como deveria conversar com um menino de dez anos?

- Você sabe, quando recua com seu arco e mira a sua flecha, o que supõe que a pupila dos olhos faça?

- O músculo no fundo do seu estômago - onde é o fundo do estômago quando se é um menino pequeno?

\section{Menino de 12 anos}

- O que devemos fazer?

- Ou, se forem seis e cinco, pode começar - que diferença fazem (sic!) cinco minutos?

- E o que deveria fazer? 
Diferentemente da categoria anterior a esta, a pergunta retórica pressupõe que o interlocutor - o cliente, no caso - não sabe a resposta. Serve então para instigá-lo a pensar e também para criar uma ponte - novamente estreitar o rapport entre terapeuta/cliente - à medida que parece inseri-lo na conversa para que deixe de "fazer parte do problema", sendo convidado a "participar da solução" como quando Erickson pergunta ao menino de 12 anos "O que devemos fazer?".

\section{P- 24 - Falsa negativa}

Ann

- Você realmente não contou a verdade.

- Você não é uma bobalhona gorda comum repulsiva

\section{Menino de 10 anos}

- Você não é uma dessas pessoas de peito afundado e ombros caídos

\section{Menino de 12 anos}

- Mas você não vai gostar do modo como vou conduzi-la

- Você não vai gostar nem um pouco

- Sempre verifique cada linha e cada palavra, porque você não vai querer deixar nenhuma letra de fora.

- Você não quer deixar de fora nenhuma pequena parcela da cura que ocorrerá numa úlcera como essa.

A falsa negativa nega aquilo que, de fato, Erickson quer enfatizar. Quando o terapeuta afirma que Ann "não é uma bobalhona gorda comum" ou que o menino de dez anos "não é uma pessoa de peito afundado e ombros caídos", o que, de fato, pretende é enfatizar a Ann e ao menino que a autoimagem que construíram acerca de si próprios não corresponde à realidade. Aplica-se também para criar um efeito suspensivo como em "Você não vai gostar nem um pouco" ou "Você não vai gostar do modo como vou conduzi-la". A falsa negativa confunde o cliente e, 
simultaneamente, amplia sua sensação de angústia em relação ao que é negado. Ao mesmo tempo, permite um espelhamento eficaz com o terapeuta, uma vez que este parece, solidariamente, negar aquilo que incomoda o cliente.

\section{$P$ - 25 - Emprego de "ou"}

\section{Menino de 12 anos}

- Naturalmente, se acordar às cinco para as seis, pode muito bem começar ao invés de esperar as seis horas. $\underline{\mathrm{Ou}}$, se forem seis e cinco, pode começar que diferença fazem (sic!) cinco minutos?

- Agora, você pode escrever com a caneta, ou com um lápis

- A cada duas horas, poderia fazer um intervalo para um lanche - constituído essencialmente por um suco de frutas - ou para tomar água

O uso "artístico" da conjunção "ou" parece oferecer alternativas para o cliente. No entanto, Erickson aponta opções apenas quando as ações por ele sugeridas são absolutamente irrelevantes para o processo. Escrever com lápis "ou" com caneta não faria a menor diferença, no caso do menino de doze anos - o importante era que ele se dedicasse à escrita. Da mesma forma, a atividade não seria prejudicada se o menino começasse às cinco para as seis "ou" às seis e cinco.

\section{P - 26 - Predicado de conscientização}

\section{Ann}

- Vou falar claramente de modo que ficará sabendo como realmente é

- Conhece alguns fatos da vida

- Penso que sabe que não hesitarei em dizer a verdade.

- Agora que sabe que posso lhe dizer a verdade, feche os olhos e entre em transe profundo

- Balance a cabeça e faça exatamente o que lhe ordeno, porque sabe que the direi a verdade 
- ... reviu todas as suas tarefas, solicitei-lhe que recordasse, uma por uma, cada tarefa, e percebesse se lhe eram dirigidas especialmente.

\section{Menino de 12 anos}

- Você os tem tomado por dois anos

- Você sabe que levará as coisas muito mais a sério se se levantar cedo para fazê-las, porque este é um negócio muito sério

- Eu sabia o que tinha que fazer

Os predicados de conscientização reafirmam o contrato de confiança estabelecido entre cliente e terapeuta. O terapeuta chama a atenção do cliente para algum pressuposto, algo que o cliente "sabe", "conhece" ou pode "perceber". Assim, tudo é colocado "às claras", não há por que o cliente deixar de atender as solicitações do terapeuta.

\section{P - 27 - Uso de advérbios / adjetivos}

Ann

- Pensei que talvez pudesse ser hipnotizada

- Talvez consiga aprender

- Você é suficientemente inteligente para ter se graduado no segundo grau, e talvez seja inteligente o suficiente para aprender a entrar no estado hipnótico

- Portanto, durma profundamente, num estado hipnótico profundo

\section{Menino de 12 anos}

- De uma maneira um tanto lenta, irritante, prolongada, emaranhada, ofereciIhe um plano terapêutico

- Descobri que sua ortografia é muito ruim 
- Sua ortografia é fraca porque, quando escreve uma palavra, você em geral deixa letras de fora

- Talvez ele quisesse escrever durante mais um fim de semana depois que ela tivesse sarado

O uso estratégico dos adjetivos por parte do terapeuta pode conduzir o cliente na direção que o terapeuta indicar: tanto podem ser motivadores quanto podem desestruturar e fragilizar o cliente, estratégia empregada por Erickson para ganhar pontos na relação de poder que se estabelece durante o atendimento terapêutico. $O$ uso do advérbio "talvez" também enfraquece o cliente - nenhuma certeza, apenas uma eventual possibilidade de realização se configura mediante esta estratégia comumente empregada por Erickson.

\subsubsection{Ocorrências referentes à segunda categoria do Modelo Milton}

A segunda categoria do Modelo Milton apresenta os Padrões de eliciação indireta. Dentre as subcategorias que fazem parte dos padrões, a análise dos três casos indica a presença dos seguintes:

\section{PEI - 1 - Ordem embutida}

Ann

- Mas no estado de transe conseguirá escutar

\section{Menino de dez anos}

- Há uma outra (cadeira) vaga, do outro lado

No caso Ann, Erickson afirma que a cliente não suportaria ouvir certas coisas se estivesse desperta. Já no estado de transe, sugere que ela "conseguirá escutar", em vez de ordenar diretamente que escute o que ele tem a dizer. Da mesma maneira, em vez de ordenar ao menino que se sente ao lado dele, simplesmente indica a 
existência da cadeira vaga, esperando que o cliente o faça sem perceber, pensando ser espontaneamente.

\section{PEI - 4 - Ordem negativa}

- Mas não pense que não pode aguentar

- $\quad$ Não perca tempo, assim como não perde tempo em fazer de si mesma uma coisa repulsiva de se olhar.

- $\quad$ Não pense em nada, não sinta nada, não faça nada, não escute nada a não ser a minha voz

- Não escute nada exceto minha voz, não enxergue nada, não pense em nada, exceto naquilo que quero que pense. Não faça nada, a não ser o que the digo para fazer

\section{Menino de 12 anos}

- Na verdade, eu não me importaria se ele parasse às quatro da tarde. Ao tornar o horário de encerramento um tema indiferente para mim, retirei o aspecto punitivo

As ordens negativas também assinalam o conteúdo do que é negado. Dizer "não pense", pressupõe que alguém está pensando em algo e/ou indiretamente "faz pensar". "Não escute", antes de "vedar os ouvidos" de alguém, faz com que a pessoa "ouça". Na prática é, de fato, uma eliciação indireta: aguça primeiro para, em seguida, negar. É como se Erickson abrisse uma concessão ao cliente antes de lhe apresentar uma série de proibições.

\section{PEI - 5 - Postulados de conversação}

Ann

- Está fazendo isto?

- Sabe o que é uma biblioteca? 
As questões apresentadas são típicos "postulados de conversação" do Modelo Milton. Embora admitam "sim" ou "não" como respostas, o que Erickson pretende mesmo é promover espelhamento, fazendo com que Ann acompanhe seu raciocínio, ainda que os comandos do terapeuta possam parecer confusos à cliente. "Facilitando" o acompanhamento, Erickson reforça seu rapport com Ann, alicerçando sua confiança.

\section{PEI - 6c - Ambiguidade de escopo}

\section{Menino de doze anos}

- Mas você não vai gostar do modo como vou conduzi-la. Porque vou fazer algo que vai limpar a úlcera. Você não vai gostar nem um pouco; só vai gostar de que (sic!) a úlcera sare - disso você vai gostar de verdade

Um exemplo típico da ambiguidade ericksoniana em ação: proposições negativas e positivas se alternam gerando confusão de sentido quanto ao resultado final: o menino iria ou não gostar do que Erickson Ihe indicaria? E do resultado final, gostaria ou não? O jogo da sucessão de palavras que negam e reafirmam se reveste de conteúdo hipnótico, levando o cliente, em geral, a concordar com a parte que melhor lhe aprouver.

\subsubsection{Ocorrências referentes à terceira categoria do Modelo Milton}

A terceira e última categoria do Modelo Milton refere-se a Padrões de Metáforas e apresenta, como subcategorias, a Violação de restrições seletivas e as Citações. Nos casos selecionados foram encontradas:

PM - 1 - Violação de restrições seletivas

Ann 
- Você é o barril de gordura mais gordo, sem graça, repulsivamente horrendo que já vi,

- Seu nariz foi simplesmente amassado em sua cara.

- Seus pés derramam-se pelas beiradas dos sapatos

- [...] o fato de você ter devorado os alimentos para ficar parecendo um balde de lixo cheio demais demonstra que precisa aprender algo

\section{Menino de 10 anos}

- O futebol é um belo jogo para quem é só um monte de músculos.

- Quando o estômago quer se livrar da comida, o músculo circular se abre, esvazia o estômago, e se fecha até que a próxima refeição seja ingerida para ele digerir. (comparação indireta dos músculos do estômago com os músculos responsáveis pela micção)

- Tudo o que eu fiz foi conversar sobre os músculos circulares existentes no fundo do estômago, que podiam se fechar e segurar os conteúdos

Erickson desenha metaforicamente o perfil de Ann a partir das piores imagens: "um barril de gordura", "um balde cheio de lixo", "um nariz 'amassado' na cara", "pés se 'esparramando' pelas beiradas dos sapatos". Uma criatura amorfa, superdimensionada, horrenda que, mesmo assim, deveria ter esperança, uma vez que pessoas se casam com 'coisas' ainda piores do que ela. Da mesma maneira, usa a metáfora do funcionamento dos músculos do estômago para sugerir ao menino de dez anos que seria capaz de ter controle sobre sua micção. Usa também a metáfora que reduz jogadores de futebol a "um monte de músculos" - insinuando que maiores habilidades não são requeridas para esse esporte, a fim de desmerecer as qualidades do irmão mais velho do menino de dez anos. Por meio da criação dessas imagens, consegue sintetizar o problema, a partir do qual aponta soluções, buscando espelhamento junto ao cliente, reafirmando seu papel de líder no contexto da terapia estratégica e conduzindo o cliente ao resultado almejado. 


\section{PM - 2 - Citações}

\section{Menino de dez anos}

- Sabe, sou médico, e os médicos sempre têm grande interesse pela compleição do homem. Você tem um belo tórax redondo, é peitudo (...) Tem um belo peito, que se sobressai.

Embora admita ser médico, Erickson generaliza sua própria opinião para toda a classe médica. Os enunciados seguintes parecem sintetizar a opinião da categoria quanto à compleição física do rapaz, visando a um reforço de sua autoestima. Indiretamente, o terapeuta provoca uma reação positiva no menino ao evidenciar suas características físicas admiráveis. .

Conforme fica claro neste capítulo, Erickson tem um método que se poderia chamar de peculiar, cuja força está na exploração das potencialidades do discurso como um instrumento de mudança na trajetória de seus clientes.

Esta metodologia fica exposta na estratégia aqui desenhada: em cada um dos casos, encontram-se diferentes conjuntos de categorias em ação - aquelas que Erickson avalia como necessárias para tratar de cada um de seus clientes. Por outro lado, a leitura horizontal confirma a presença de todas as categorias e subcategorias, tanto do Metamodelo quanto do Modelo Milton, nos casos estudados. Se nem todos os casos apresentam todas as categorias e/ou subcategorias propostas por Bandler e Grinder, isso comprova a estratégia de Erickson: empregar, para cada cliente, somente o que cada caso requer. 


\section{CONCLUSÃO}

Enquanto está sentado nessa cadeira, quero que escute. Farei perguntas. Você as responderá e não dirá nem um pouquinho a mais nem a menos do que devo saber. Isto é tudo o que você vai fazer - nada mais.

MILTON ERICKSON

Este estudo explicitou indicadores da relevância de Milton Erickson no quadro da Psicologia atual através de suas contribuições relativas, especialmente, a um novo olhar sobre a hipnose, sobre as questões da subjetividade que se apresentam nas relações entre terapeuta e cliente, e sobre as potencialidades do discurso. No tocante ao uso da hipnose, as diferenças entre Freud e Erickson ora apresentadas indicam a riqueza das técnicas hipnóticas e como, ainda hoje, a hipnose merece mais investigações empíricas. No que se refere à subjetividade, é possível identificar um novo paradigma no campo da Psicologia através do enfoque ericksoniano. Quanto às potencialidades do discurso, o Metamodelo e o Modelo Milton indicam, através de suas categorias e subcategorias, como a subversão de normas gramaticais e sintáticas explorada por Erickson pode se traduzir em efeito hipnótico.

No que se refere aos avanços de Erickson relativos à hipnose, o mais expressivo é a substituição do transe hipnótico tradicional por táticas terapêuticas como a indução indireta e o uso de metáforas, a fim de provocar efeito hipnótico. Assim, o terapeuta é capaz de explorar o modelo de mundo do cliente enquanto este experimenta 0 efeito hipnótico e de agir em consonância com os anseios do cliente para efetivar a mudança e desenhar o cenário futuro. Não raro, Erickson tratava o sintoma apresentado pelo cliente por meio de metáforas, sem sequer abordar a causa original, o que evidencia outro diferencial importante em relação aos modelos clássicos de terapias que se apóiam nas relações causais.

A questão da sugestibilidade, relacionada à da subjetividade do sujeito, é outro ponto importante: diferentemente do transe hipnótico tradicional, em que 0 hipnotista, exclusivamente, oferece sugestões ao cliente, que fica à sua mercê, no estado hipnótico segundo o enfoque ericksoniano ocorre um jogo interacional em que o sujeito é instigado a agir vislumbrando a construção de seus próprios resultados. Embora o inconsciente do sujeito seja acionado através de técnicas que 
promovem efeito hipnótico, as sugestões encaminhadas pelo terapeuta - que muitas vezes se assemelham a ordens - passam pelo crivo da consciência do cliente, diferentemente do que ocorre na Psicanálise.

Cabe ressaltar que Freud, tendo estudado com alguns dos maiores expoentes da hipnose, não encontrou para a técnica um emprego diferente daquele apresentado pelos grandes hipnotistas de sua época, abandonando-a em vista de suas descobertas acerca do inconsciente. Como possibilidade de estudos futuros, acredita-se que uma comparação mais profunda da obra de Erickson com a obra freudiana terá alta potencialidade de explicitação da terapia e da hipnose como temas que podem enriquecer o quadro da Psicologia atual, mostrando caminhos distintos para a cura. O cotejamento dos casos "Anna O." e "Srta. S" poderá acentuar as diferenças entre as abordagens freudiana e ericksoniana no tocante ao uso da hipnose e seus resultados.

A hipnoterapia ericksoniana também aprofundou as técnicas de espelhamento e rapport, empregadas pela hipnose na indução dos transes. O uso cuidadoso da linguagem verbal e não-verbal é empregado não apenas para diagnosticar o sintoma como também para promover a mudança necessária para o cliente, passo a passo e com a colaboração deste.

A pesquisa mostrou ainda que Erickson dedicou sua vida ao estudo, à prática e ao ensino de técnicas relacionadas à psicoterapia, tendo contribuído com figuras expressivas de seu tempo como Margaret Mead e Gregory Bateson, além de ter influenciado os trabalhos de Ernest Rossi, Jeffrey Zeig, Jay Haley, John Weakland, Richard Bandler e John Grinder, como mentor e parceiro. A terapia estratégica de Haley ou a Programação Neurolinguística de Bandler e Grinder certamente não teriam alcançado seus propósitos caso seus idealizadores não tivessem acompanhado a práxis ericksoniana de perto, a partir da qual esboçaram os fundamentos mais importantes de suas teorias.

No caso da terapia estratégica, é possível apontar, como traço relevante, o novo paradigma terapêutico proposto no modelo ericksoniano relativo à subjetividade do sujeito na busca de soluções individuais e de mudanças capazes de integrar seu modelo de mundo. Nele, o terapeuta intervém diretamente no processo de mudança do sujeito, diferenciando-se do paradigma tradicional da Psicanálise, em que isso não ocorre. 
Além disso, em vez de buscar no passado do cliente as causas do problema atual, Erickson, num fazer pragmático, prefere oferecer sugestões práticas a partir do presente, desenhando, junto com seu cliente, ações que promoverão as mudanças necessárias para a criação de um novo cenário no futuro, em que este se insere livre de amarras, com o olhar focado na direção de possíveis sucessos.

O foco no passado que caracteriza a obra de Freud e o foco no presente e no futuro que caracterizam a obra ericksoniana é mais um dos indicadores da distância entre ambos. Erickson afirmava que "compreender o passado não muda o passado". E uma vez que o método ericksoniano objetiva a mudança acelerada do quadro de insatisfação do cliente, Erickson, ao longo do tempo, colocou a regressão à margem de sua terapia, o que pode ser questionado pela comunidade psicanalítica. Priorizar o sintoma e não sua causa, este é também um dos postulados da práxis ericksoniana.

Embora, diferentemente de Freud, Erickson não tenha escrito um tratado formal sobre seus achados ao longo dos anos, os padrões ericksonianos de linguagem, bem como seus efeitos, tornaram-se evidentes para aqueles que acompanharam de perto seus atendimentos e seminários. Seguidores como Rossi, Haley, Zeig, Bandler e Grinder enxergaram a riqueza de seus ensinamentos e os perpetuaram em seus trabalhos, mais tarde consagrados. Erickson era um professor dedicado, sempre disposto a responder as questões propostas por seus alunos, como se pode constatar através das transcrições de muitos dos workshops por ele ministrados. Como o próprio Erickson dizia, ele sabia "o que" fazia, mas não sabia explicar ao certo "como" fazia. Coube a seus seguidores a tarefa de organizar e divulgar o legado de Erickson.

Em relação às primeiras críticas, que apontavam Erickson como dono de uma personalidade incomum, à qual atribuíam o sucesso de seus atendimentos, fica claro que tal argumento não se sustenta e que havia sim, subjacente à práxis ericksoniana, um método recuperado ao longo do tempo por seus seguidores. Atribuir a Erickson a capacidade exclusiva de curar através da hipnoterapia ericksoninana seria o mesmo que acreditar que somente Freud seria capaz de obter resultados efetivos com a Psicanálise. É certo que sua formação em medicina permitia que criasse curiosas e eficazes metáforas relacionadas ao funcionamento do corpo humano; mas, tendo mostrado o "caminho das pedras", nada impede que 
um terapeuta possa aprimorar seus estudos relacionados à anatomia e à fisiologia para se valer da mesma estratégia, a fim de obter resultados semelhantes.

A técnica terapêutica ericksoniana explora as potencialidades do discurso. Ao subverter as construções linguísticas cravadas na mente inconsciente do sujeito por exemplo, com o uso de uma conjunção aditiva onde a gramática pediria uma adversativa - Erickson cria um vínculo causal entre ideias não-relacionadas ou até mesmo contrárias, gerando momentâneo efeito hipnótico, obtendo, assim, a colaboração do cliente para a ação indicada pelo terapeuta. O reforço "artístico" que promove com o uso de advérbios de modo para enfatizar os adjetivos que os sucedem causa também o mesmo efeito, assim como o emprego de generalizações, pressuposições e ambiguidades, sempre empregadas no melhor tempo e lugar, de acordo com a necessidade do cliente. Além disso, o uso primoroso de técnicas de linguagem não-verbal como o espelhamento e o rapport, torna suas táticas discursivas ainda mais eficazes.

O pragmatismo de Erickson costuma ser questionado, especialmente por aqueles que buscam conhecer seu método em vez de experimentá-lo. Talvez esse questionamento advenha do conhecimento superficial da obra de Erickson - é comum encontrar pessoas que criticam sua obra sem mesmo conhecê-la.

Além da categorização cuidadosamente organizada pelos seguidores de Erickson, sintetizada no Metamodelo e no Modelo Milton de Bandler e Grinder, este estudo aponta para a possibilidade de um modelo de análise de conteúdo dos casos recolhidos na vasta literatura sobre o terapeuta, em que as categorias e subcategorias são destacadas (leitura vertical) e posteriormente agregadas (leitura horizontal) a partir de variados exemplos que comprovam o efeito hipnótico das ações de Erickson em suas sessões terapêuticas. Cai por terra o mito e emerge 0 valor da técnica terapêutica que, sem uma racionalidade fundada num caminho explícito, apresentou significativos avanços nos campos da hipnose, da clínica terapêutica e do uso da linguagem comum com efeito hipnótico. O crescente interesse em diversos países do mundo sobre o trabalho de Erickson, especialmente a partir dos anos 2000, consagra sua obra e permite inscrever seu nome na Psicologia como o grande mestre da hipnoterapia e da terapia estratégica. 


\section{REFERÊNCIAS BIBLIOGRÁFICAS}

BANDLER, Richard; GRINDER, John. A estrutura da magia: um livro sobre terapia e linguagem, São Paulo: Summus, 1977.

BANDLER, Richard; GRINDER, John. Atravessando: passagens em psicoterapia, São Paulo: Summus, 1984.

; Patterns of the hypnotic techniques of Milton H. Erickson, M.D., I, Scotts Valley: Grinder \& Associates, [sd].

; Sapos em príncipes, São Paulo: Summus, 1982.

CAMERON-BANDLER, L. Soluções: antídotos práticos para problemas sexuais e de relacionamento, São Paulo: Summus, 1991.

CHOMSKY, Noam. Aspectos da teoria da sintaxe, Coimbra: Armênio Amado, 1975.

; Estruturas sintáticas, Lisboa: Edições 70, s.d.

ERICKSON, Milton: Complete Works. Disponível em <http://www.4shared.com/office/k5HvjCA2/Milton_Erickson_-_Complete_Wor.html>. Acesso em: 13 mar. 2011.

; HERSHMAN, Seymour.; SECTER, Irving L. Hipnose médica e odontológica, Campinas: Livro Pleno, 2003.

; ROSSI, Ernest. L. O homem de fevereiro, Campinas: Livro Pleno, 2003.

FREUD, Sigmund. Artigos sobre hipnotismo e sugestão: a psicoterapia da histeria, Rio de Janeiro: Imago, 1998.

; A história do movimento psicanalítico. In ; Os pensadores, São Paulo: Abril, 1978

; BREUER, J. Estudos sobre a histeria, Josef Breuer e Sigmund Freud, vol.2, Disponível em <http://www.psbnacional.org.br/bib/b42.pdf>. Acesso em: 13 mar. 2011. (1883)

GAY, P. Sigmund Freud: obras psicológicas. Rio de Janeiro: Imago, 1992. 1989.

; Freud: uma vida para o nosso tempo. São Paulo: Companhia das Letras,

GOMES, J. C. V. Manual de psicoterapia familiar, Petrópolis: 1987. 
HALEY, Jay. Advanced techniques of hypnosis and therapy - selected papers of Milton H. Erickson, M.D., Grune \& Stratton: Nova York, 1967.

; Terapia não-convencional: as técnicas psiquiátricas de Milton $\mathrm{H}$. Erickson, São Paulo: Summus, 1991.

HOFFMAN, Lynn. Fundamentos de La terapia familiar: um marco conceptual para El cambio se sistemas., Fondo de Cultura Económica: México, 1992.

LANKTON, S. R. Ericksonian strategic therapy. In Zeig, J.K \& Munion, W. M. What is psychotherapy? Contemporary perspectives, San Francisco: Jossey-Bass

; Milton Erickson's Contribution To Therapy. Epistemology - not Technology. Disponível em <http://lankton.com/epist.htm\#G>. Acesso em: 13 mar. 2011. (s/d)

; Milton Erickson's: La vision del mundo "cambiante" y la terapia. Disponível em <http://pt.scribd.com/doc/72007524/Vision-de-mundo-cambiante>. Acesso em: 13 mar. 2011. (1997)

; LANKTON, C.H. The answer within: a clinical framework of ericksonian therapy. Nova York: Brunner-Mazel, 1983.

LEÓN, M. P., Psicoterapia ericksoniana: el legado de Milton H. Erickson a la psicoterapia actual. Disponível em <http://pt.scribd.com/doc/11560543/PachecoLeon-El-Legado-de-Milton-Erickson-a-La-pia-Actual>. Acesso em: 13 mar. 2011. (2002)

MASSON, J. M. Against therapy. Nova York: Atheneum, 1988.

MEIRELES, J. A.; RAPOSO, E. P. "Introdução" in Aspectos da teoria da sintaxe. Coimbra: Armênio Amado, 1975.

MEZAN, R. Freud: pensador da cultura. São Paulo: Brasiliense, 1986.

; Sigmund Freud: a conquista do proibido. São Paulo: Brasiliense, 1982.

NEUBERN, M. S. Milton H. Erickson e o cavalo de Tróia: a terapia não convencional no cenário da crise dos paradigmas em psicologia clínica. Disponível em <http://www.scielo.br/pdf/prc/v15n2/14359.pdf>. Acesso em: 13 mar. 2011. (2002)

PIAGET, J.; GRECO, P. Aprendizagem e conhecimento, Rio de Janeiro: Freitas Bastos, 1974.

ROSEN, S. My voice will go with you: the teaching tales of Milton H. Erickson. Nova York: W. W. Norton, 1991. 
ROSSI, E.; RYAN, M. O. Mind-body communication in hypnosis: the seminars, workshops and lectures of Milton H. Erickson. Nova York: Irvington, 1986.

ZEIG, Jeffrey K. Os seminários didáticos de psicanálise de Milton H. Erickson, Rio de Janeiro: Imago, 1983.

Vivenciando Erickson, Campinas: Psy, s/d. 


\section{APÊNDICE I}

Os textos a seguir exemplificam possibilidades de recortes para a constituição do corpus; trata-se da reprodução de atendimentos terapêuticos de Milton Erickson que tornam evidentes o estilo característico de suas consultas.

\section{O caso $A n n^{18}$}

Certa feita, um problema mais grave apresentou-se a Erickson. Uma mulher de vinte e um anos the telefonou pedindo ajuda, dizendo ter certeza de que ele não a receberia. Quando chegou ao consultório, disse: "É como eu lhe disse, agora vou embora. Meu pai está morto, minha mãe está morta, minha irmã está morta, e isto é tudo que me resta". Erickson abordou o problema da seguinte maneira:

Eu pedi com insistência que se sentasse e, após pensar rapidamente, percebi que a única maneira possível de me comunicar com ela era através da dureza e da brutalidade. Teria de usar de brutalidade para convencê-la de minha sinceridade. Ela interpretaria mal qualquer amabilidade e não conseguiria acreditar na linguagem cortês. Teria que convencê-la totalmente de que a compreendia e reconhecia seu problema, e que não tinha medo de falar aberta, livremente, sem nenhuma emoção e com franqueza.

Retomei sua história resumidamente e, a seguir, fiz duas perguntas importantes: "Qual é sua altura e seu peso?". Com um olhar de sofrimento extremo, ela respondeu: "Tenho um metro e sessenta. Peso noventa e cinco quilos. Sou uma bobalhona gorda comum. Ninguém olharia para mim, a não ser com repulsa”.

Este comentário me ofereceu a abertura conveniente, e eu lhe disse: "Você realmente não contou a verdade. Vou falar claramente de modo que ficará sabendo como realmente é e compreenderá que conheço você. Então acreditará, realmente acreditará, no que tenho a lhe dizer. Você não é uma bobalhona gorda comum repulsiva. Você é o barril de gordura mais gordo, sem graça, repulsivamente horrendo que já vi, e é aterrador olhar para você. Você já cursou o primeiro grau. Conhece alguns fatos da vida. Ainda assim, aqui está, com seu metro e pouco de

${ }^{18}$ Excerto de HALEY, Jay, Terapia não-convencional - as técnicas psiquiátricas de Milton H. Erickson, p. 111115. 
altura, pesando entre noventa e noventa e cinco quilos. Você tem o rosto mais sem graça que já vi. Seu nariz foi simplesmente amassado em sua cara. Seus dentes são tortos. Seu maxilar inferior não se encaixa no superior. Seu rosto é insignificantemente disperso. Sua testa é chocantemente baixa. Nem mesmo seu cabelo está penteado decentemente. E este vestido que está usando - bolinhas, milhões, bilhões delas. Você não tem gosto nem para se vestir. Seus pés derramamse pelas beiradas dos sapatos. Para ser curto e grosso: você é uma confusão medonha. Mas precisa mesmo de ajuda. Penso que sabe que não hesitarei em dizer a verdade. Você precisa saber a verdade a seu respeito antes mesmo de poder aprender coisas necessárias para se ajudar. Mas não pense que não pode aguentar. Por que veio me ver?".

Ela respondeu: "Pensei que talvez pudesse ser hipnotizada para conseguir perder peso". Respondi: "Talvez consiga aprender a entrar em transe hipnótico. Você é suficientemente inteligente para ter se graduado no segundo grau, e talvez seja inteligente o suficiente para aprender a entrar no estado hipnótico. Será uma oportunidade para eu lhe dizer algumas outras coisas descorteses. Coisas que acredito que não suportaria ouvir se estivesse desperta. Mas no estado de transe conseguirá escutar. Pode compreender. Fazer algo. Não muito, com certeza, porque você está numa situação horrivelmente desvantajosa. Mas quero que entre em transe. Quero que faça tudo o que eu lhe ordenar, porque o fato de você ter devorado os alimentos para ficar parecendo um balde de lixo cheio demais demonstra que precisa aprender algo para não ser tão ofensiva aos olhos humanos. Agora que sabe que posso lhe dizer a verdade, feche os olhos e entre em transe profundo. Não perca tempo, assim como não perde tempo em fazer de si mesma uma coisa repulsiva de se olhar. Entre completamente num profundo transe hipnótico. Não pense em nada, não sinta nada, não faça nada, não escute nada a não ser a minha voz. Você entenderá o que digo - e ficará contente por eu me dispor a falar com você. Há muitas verdades que quero lhe dizer. Você não conseguiria encará-las em estado desperto. Portanto, durma profundamente, num estado hipnótico profundo. Não escute nada exceto minha voz, não enxergue nada, não pense em nada, exceto naquilo que quero que pense. Não faça nada, a não ser o que lhe digo para fazer. Seja apenas um autômato impotente. Está fazendo isto? Balance a cabeça e faça exatamente o que lhe ordeno, porque sabe que lhe direi a 
verdade. A primeira coisa que farei é fazer com que - ou melhor, ordenar a você conte certos fatos a seu respeito. Você pode falar, embora esteja em transe profundo. Responda a cada pergunta de maneira simples, mas informativa. O que há de importante sobre seu pai?"

Sua resposta foi: "Ele me odiava. Era um bêbado. Vivíamos em guerra. Ele costumava me chutar. Isto é tudo que lembro de meu pai. Bêbado, batendo em mim, me chutando, me odiando". "E sua mãe?". "Era igual, mas morreu primeiro. Ela me odiava ainda mais de que meu pai. Me tratava ainda pior do que ele. Só me mandaram ao ginásio porque sabiam que eu odiava a escola. Tudo o que eu podia fazer durante o ginásio era estudar. Eles me fizeram morar na garagem com minha irmã. Ela nasceu deficiente. Era pequena e gorda. Tinha a bexiga do lado de fora do corpo. Estava sempre doente. Tinha uma doença dos rins. Nós nos amávamos. Só tínhamos uma à outra para amar. Quando ela morreu da doença renal, eles disseram: 'Ótimo'. Não me deixaram ir ao enterro. Apenas enterraram a única coisa que eu amava. Eu era uma caloura no ginásio. No ano seguinte, minha mãe se matou de tanto beber. E meu pai se casou com uma mulher pior do que minha mãe. Ela não me deixava entrar em casa. Trazia um mingau para a garagem e me fazia comer. Dizia que eu podia me consumir até morrer. Que já iria tarde. Era uma bêbada como minha mãe. A assistente social também não gostava de mim, mas me encaminhou para fazer alguns exames médicos. Os médicos não gostavam de me tocar. Agora minha madrasta e minha irmã estão mortas. O seguro social me mandou procurar um emprego. Consegui um, onde tenho que esfregar o chão. Os homens do lugar caçoam de mim. Eles oferecem dinheiro uns aos outros para ter uma relação comigo, mas ninguém, aceita. Não sirvo para nada. Mas gostaria de viver. Tenho onde morar. Um barracão velho. Não ganho muito - como papa de farinha de milho e batatas, ou algo assim. Pensei que talvez pudesse me hipnotizar e fazer algo por mim. Mas acho que não vai adiantar nada."

Da maneira mais insensível e peremptória perguntei: "Sabe o que é uma biblioteca? Quero que vá a uma biblioteca e retire livros de antropologia. Quero que olhe todos os tipos chocantes de mulheres com que os homens se casam. Há fotografias delas nos livros da biblioteca. Selvagens primitivos se casarão com coisas que têm uma aparência pior do que a sua. Olhe um livro atrás do outro e fique curiosa. Então leia livros que narrem como mulheres e homens se desfiguram, fazem tatuagens, se 
mutilam para parecerem ainda mais horrorosos. Passe a maior parte do tempo que puder na biblioteca. Faça isto direito e volte em duas semanas".

Eu a despertei do transe com essas sugestões pós-hipnóticas, e ela saiu do consultório da mesma maneira acachapada que tinha entrado. Voltou duas semanas mais tarde. Eu lhe disse para não perder tempo - para entrar em transe profundo imediatamente. Perguntei se havia encontrado alguma fotografia que achasse desagradável. Ela contou que havia encontrado retrato das mulheres esteatopígicas dos hotentotes, e das mulheres com lábios tipo bico de pato, de escarificação em algumas tribos africanas, de estranhos rituais de mutilação.

Ordenei a ela que se dirigisse para a área mais movimentada da cidade (em estado desperto) e observasse as formas peculiares e as faces das coisas com que os homens se casam. Ela deveria fazer isto durante uma semana. Na semana seguinte, deveria olhar formas e faces peculiares das coisas com que as mulheres se casam, e se assombrar com isto.

Obedientemente, ela retornou para a entrevista seguinte, entrou em transe à simples menção do assombro com que observara mulheres quase tão sem graça quanto ela usando alianças. Ela havia visto homens e mulheres que pareciam marido e mulher, ambos horrivelmente gordos e desengonçados. Disse-lhe que estava começando a aprender alguma coisa.

Sua tarefa seguinte era ir à biblioteca e ler todos os livros que conseguisse sobre a história da cosmetologia - descobrir o que constitui a beleza desejável aos olhos humanos. Ela fez uma ampla pesquisa e, na semana seguinte, entrou no consultório sem timidez, mas ainda continuava vestida com a roupa de bolinhas. Então disse-Ihe que voltasse à biblioteca e se dedicasse aos livros que tratavam e costumes humanos, vestuário e aparência - para descobrir alguma coisa retratada que tivesse, no mínimo, quinhentos anos e ainda fosse bonita. Ann voltou, desenvolveu um transe assim que entrou no consultório, sentou-se e falou longo tempo sobre o que havia visto nos livros.

Disse-Ihe que sua próxima tarefa seria muito difícil. Durante duas semanas, ela deveria entrar na primeira loja de vestuário feminino que encontrasse, depois noutra, usando seu assustador vestido de bolinhas. Deveria perguntar à vendedora o que deveria usar - perguntar tão séria e honestamente que obteria uma resposta. Depois 
desta tarefa, ela relatou que várias mulheres mais velhas a haviam chamado de "queridinha" e lhe explicado por que não deveria usar milhões e milhões de bolinhas. Explicaram-lhe por que não deveria usar vestidos que não lhe caíam bem e acentuavam sua gordura. A próxima tarefa era gastar duas semanas com pensamentos obsessivos: por que ela, que deveria ter nascido com menos de três quilos, teria adquirido aquela enorme quantidade de gordura? Por que havia se enrolado em gordura? No relato desta tarefa, ela declarou que não conseguiria chegar a nenhuma conclusão.

De novo em estado de transe, dei-lhe outra tarefa. Desta vez, descobri se realmente havia alguma razão para ela pesar o que pesava - querer saber como seria sua aparência se pesasse somente sessenta quilos e se vestisse de modo apropriado. Ela deveria acordar no meio da noite com esta questão em mente, para em seguida tornar a adormecer tranquilamente. Após alguns outros transes, nos quais reviu todas as suas tarefas, solicitei-lhe que recordasse, uma por uma, cada tarefa, e percebesse se lhe eram dirigidas especialmente.

Ann tinha consultas a cada quinze dias. Dentro de seis meses, ela entrou, com grande interesse, para explicar que não conseguiria encontrar nenhuma razão para pesar tanto - ou para se vestir tão mal. Ela havia lido bastante sobre cosmetologia, penteados e maquilagem. Havia lido livros sobre cirurgia plástica, sobre ortodontia. Perguntou, tristemente, se não Ihe seria permitido saber o que poderia fazer a seu respeito.

Depois de um ano, estava pesando sessenta e cinco quilos. Seu gosto para roupas era excelente, e estava num emprego muito melhor. Estava se inscrevendo na universidade e, embora ainda pesasse sessenta e três quilos, estava noiva e ia se casar. Ela extraíra e substituíra dois dentes que haviam crescido fora de alinhamento. Seu sorriso era realmente atraente. Trabalhava como artista de moda para catálogos e jornais.

Ann trouxe o noivo para me conhecer. Ela entrou no consultório primeiro e disse: "Este maldito tolo é tão burro! Ele pensa que sou bonita. E eu nunca vou desiludi-lo. Seus olhos brilham quando olha pra mim. Mas tanto você quanto eu sabemos a verdade. Tenho dificuldade em manter peso - e tenho medo de engordar de novo. Mas realmente sei que ele me ama como sou". 
Eles estão casados há quinze anos e têm três belos filhos. Ann fala livremente sobre sua terapia, pois se lembra de tudo que lhe foi dito. Mais de uma vez, afirmou: "Quando você falou aquelas coisas horrorosas a meu respeito, foi tão franco! Sabia que me dizia a verdade. Mas, se não tivesse me colocado em transe, não teria feito nenhuma das coisas que me fez fazer".

\section{Menino de dez anos ${ }^{19}$}

Uma mãe me procurou e contou sobre o filho de dez anos que molhava a cama todas as noites. Eles [os pais] haviam feito tudo o que era possível para que parasse. Eles o arrastaram para me ver - literalmente. O pai segurava por uma mão, a mãe pela outra, e o menino arrastava os pés. Eles os [sic] deitaram com o rosto para o chão no meu consultório. Empurrei os pais para fora e fechei a porta. $O$ menino urrava.

Quando parou para recuperar o fôlego, eu disse: "Que maneira estúpida de trazer você aqui! Não gosto nem um pouco". Ele ficou surpreso de eu ter dito isto. Hesitou, enquanto tomava fôlego, e eu lhe disse que podia ir em frente e berrar de novo. Ele deixou escapar um grito e, quando fez uma pausa para respirar, soltei um grito. Ele se voltou e me encarou, e eu disse: "É a minha vez". Então disse: "Agora é a sua vez", e ele gritou de novo. Eu gritei, e então disse que era a vez dele. Sugeri: "Poderíamos continuar fazendo turnos, mas isso seria extremamente cansativo. $\mathrm{Na}$ minha vez, vou simplesmente me sentar naquela cadeira. Há uma outra vaga, do outro lado". Quando chegou a minha vez, sentei-me na cadeira e ele sentou-se na outra. A expectativa havia sido estabelecida - eu estabelecera que nos revezássemos nos gritos, e mudei o jogo ao propor turnos para sentar. A seguir, disse "Sabe, seus pais me mandaram curar você do hábito de molhar a cama. Quem eles pensam que são para me dar ordens?". Ele havia recebido muitos castigos dos pais, de modo que, ao dizer isso, assinalei de que lado da cerca eu estava. Disse então: "Prefiro conversar com você sobre várias outras coisas. Vamos simplesmente deixar de lado a questão de molhar a cama. Agora, como deveria conversar com um

\footnotetext{
${ }^{19}$ Excerto de HALEY, Jay, Terapia não-convencional - as técnicas psiquiátricas de Milton $\mathrm{H}$. Erickson, p. 190-191.
} 
menino de dez anos? Você frequenta a escola. Você tem um belo pulso compacto; tornozelos compactos. Sabe, sou um médico, e os médicos sempre têm grande interesse pela compleição do homem. Você tem um belo tórax redondo, é peitudo. Você não é uma dessas pessoas de peito afundado e ombros caídos. Tem um belo peito, que se sobressai. Posso apostar que é bom de corrida. Com sua compleição, um tanto pequena, sem dúvida alguma tem uma boa cooOrdenação motora". Expliquei-lhe o que era coordenação, e ele disse que era provavelmente bom em esportes que requeriam perícia, não só carne e ossos. Não do tipo de esportes que qualquer cabeça-dura pudesse praticar. Mas jogos que requeriam perícia. Perguntei que esporte praticava e ele respondeu: "Jogo beisebol e atiro com arco e flecha". Perguntei: "Você é bom com o arco?". Ele respondeu: "Muito bom”. Eu disse: "Bem, naturalmente isto requer olhos, mãos, braços e coordenação corporal". Veio à tona que seu irmão mais moço jogava futebol, que era mais robusto do que ele ou qualquer outro membro da família. "O futebol é um belo jogo para quem é só um monte de músculos. Uma porção de sujeitos grandes, demasiadamente crescidos, gosta dele".

Assim, continuamos conversando sobre isto ou aquilo e sobre a coordenação muscular. Eu disse: "Você sabe, quando recua com seu arco e mira a sua flecha, o que supõe que a pupila dos olhos faça? Ela se fecha”. Expliquei que havia músculos chatos, músculos curvos, músculos longos - e também circulares, "como aquele no fundo do estômago; sabe, quando você come, este músculo se fecha, a comida fica no estômago até ser digerida. Quando o estômago quer se livrar da comida, 0 músculo circular se abre, esvazia o estômago, e se fecha até que a próxima refeição seja ingerida para ele digerir. O músculo no fundo do seu estômago - onde é o fundo do estômago quando se é um menino pequeno? É bem lá embaixo".

Assim, discutimos o assunto durante uma hora e no sábado seguinte ele veio me ver sozinho. Conversamos um pouco mais sobre esportes, sobre isto e aquilo - sem nenhuma menção a molhar a cama. Falamos sobre os escoteiros e sobre acampamentos, tudo o que pudesse interessar a um menino pequeno. Na quarta entrevista ele apareceu com um grande sorriso. Disse: "Sabe, há anos minha mãe tenta perder seu hábito. Mas não consegue”. A mãe fumava e estava tentando parar. Eu disse: "É algumas pessoas conseguem romper hábitos rapidamente, mas outras 
falam muito sobre isto e não fazem nada". Então mudamos a conversa para outros assuntos.

Uns seis meses depois, ele veio me visitar socialmente e voltou aparecer quando entrou para o segundo grau. Agora está na faculdade.

Tudo o que eu fiz foi conversar sobre os músculos circulares existentes no fundo do estômago, que podiam se fechar e segurar os conteúdos. Linguagem simbólica, naturalmente, mas toda aquela bela compleição de olhos, mãos e coordenação corporal deixou de molhar a cama sem nunca ter discutido o assunto.

\section{Menino de doze anos ${ }^{20}$}

Durante dois anos, um menino de doze anos cutucava uma ferida, uma espinha, na testa, e ela havia se tornado uma contínua ulceração. O pai e a mãe haviam esgotado todas as maneiras de punição para impedi-lo de coçar a ferida. Os professores e colegas de escola haviam tentado reformá-lo. Médicos haviam-lhe falado sobre o câncer, posto bandagens e tampado a ferida, e feito tudo o que podiam fazer para que ele não a tocasse. O menino conseguia enfiar o dedo sob o curativo e cutucar a ferida. Explicava que não conseguia controlar o impulso.

A mãe e o pai haviam feito o possível para conseguir que o menino parasse, mas discordavam quanto ao valor da punição. O pai chegou ao extremo de privar o menino de todos os brinquedos; havia vendido sua bicicleta e quebrado seu arco e flecha.

Finalmente, os pais trouxeram o menino para me ver. Tive uma entrevista com a mãe, para descobrir alguma coisa sobre a qual trabalhar. Fiquei conhecendo os valores e os deveres da casa, incluindo o fato de que o menino era obrigado a prestar pequenos serviços. Cuidava do amplo gramado e do jardim da casa, Fiquei sabendo também que a mãe tendia a ficar do lado do menino, e que ele estava bravo com o pai por vários castigos, em particular pela quebra do seu arco e flecha. Também descobri que o menino tinha um problema de grafia; quando escrevia

\footnotetext{
${ }^{20}$ Excerto de HALEY, Jay, Terapia não-convencional - as técnicas psiquiátricas de Milton H. Erickson, p. 199-202.
} 
comia letras das palavras. Gosto de ver o trabalho escolar de uma criança para verificar o que está lá.

Tive uma entrevista com o menino e com o pai, juntos, e enfoquei imediatamente a definição de prosperidade. Tomei o arco e a flecha como tema. De quem eram? 0 pai admitiu que pertenciam ao menino; ele os ganhara num aniversário. Então perguntei como uma úlcera deveria ser tratada. Concordamos que deveria ser tratada com bandagens e medicamentos de vários tipos. Perguntei como se poderia usar um arco e flecha para tratá-la. Como quebrar um arco e uma flecha tratara a úlcera? O pai ficou muito embaraçado e o filho o fitava com olhos apertados. Depois dessa discussão em que o pai ficou ruborizado e se contorceu um pouco, virei-me para o menino e perguntei se não achava que devia ao menos creditar ao pai boas intenções, a despeito de seu comportamento estúpido. Ambos tiveram que aceitar aquela declaração. Deste modo, o menino podia chamar o comportamento do pai de estúpido, mas, ao fazê-lo, estaria também dando-lhe um crédito por ser bemintencionado.

Então perguntei quanto tempo deveríamos discutir os medicamentos que não haviam funcionado. Ou podíamos esquecê-los? Eu disse: "Você os tem tomado por dois anos. Todos os remédios, desde a quebra do arco e da flecha até a venda da bicicleta, não deram certo. O que devemos fazer?". O menino sugeriu que eu me encarregasse da questão.

Eu Ihe disse: "Certo, eu me encarregarei. Mas você não vai gostar do modo como vou conduzi-la. Porque vou fazer algo que vai limpara a úlcera. Você não vai gostar nem um pouco; só vai gostar de que a úlcera sare - disso você vai gostar de verdade". Disse-lhe que queria que dedicasse todos os fins de semana à cura da ferida em sua testa - enquanto o pai faria os trabalhinhos de fim de semana para ele. O menino lançou um olhar triunfante para mim e para o pai.

Continuamos conversando sobre a faina doméstica e discutimos o corte da grama, como varrer o gramado com o ancinho, como limpara a sujeira do cachorro, semear o jardim e todo o resto. Perguntei quem inspecionava o gramado quando o menino aparava a grama. O pai inspecionava o trabalho. Eu disse: "Bem, sábado, nos intervalos de seu trabalho de curar sua úlcera, porque não pode trabalhar nela sem parar, você pode sair e inspecionar como seu pai está executando as tarefas". 
Neste ponto, o menino estava muito curioso a respeito do que faria no fim de semana para curar sua úlcera, e eu comecei o procedimento de digressão. De uma maneira um tanto lenta, irritante, prolongada, emaranhada, ofereci-Ihe um plano terapêutico. Quando agimos assim, o paciente inclina-se a desejar que cheguemos ao fim de tudo aquilo - ele quer saber o que, afinal, terá de fazer. Dá valor ao cuidado deliberado que tomamos em nossa apresentação. Sabe que não vamos empurrar as coisas para cima dele. E fica esperando que cheguemos ao que importa, e quando, finalmente, o fazemos, ele está motivado para aceitar o plano.

Disse ao menino: "Descobri que sua ortografia é muito ruim. Sua ortografia é fraca porque, quando escreve uma palavra, você em geral deixa letras de fora".

Então, continuei: "Penso que deve começar a curar sua úlcera no sábado de manhã, mais ou menos às seis horas. Você sabe que levará as coisas muito mais a sério se se levantar cedo para fazê-las, porque este é um negócio muito sério. Naturalmente, se acordar às cinco para as seis, pode muito bem começar ao invés de esperar as seis horas. Ou, se forem seis e cinco, pode começar - que diferença fazem cinco minutos?".

E prossegui: "Agora, você pode escrever com a caneta, ou com um lápis. Alguns lápis são coloridos, mas o lápis comum serve. Você pode usar caneta tinteiro, mas uma caneta esferográfica também serve. Acredito que papel comum seria o melhor. Poderia ser deste tamanho, ou um pouco maior, mais ou menos deste tamanho. Penso que seu pai pode providenciar papel suficientemente grande".

Finalmente, disse-Ihe o que ele estava curioso por ouvir: "Esta é a frase que deve escrever: 'Não acho uma boa idéia cutucar a ferida em minha testa'”. Repeti a frase lentamente e com cuidado, dizendo: "Agora, escreva devagar, escreva ordenadamente, cuidadosamente. Conte cada linha quando tiver escrito. Então escreva de novo a frase, vagarosa e cuidadosamente. Sempre verifique cada linha e cada palavra, porque você não vai querer deixar nenhuma letra de fora. Você não quer deixar de fora nenhuma pequena parcela da cura que ocorrerá numa úlcera como essa".

Disse-Ihe que não sabia quanto tempo a úlcera levaria para sarar. Acreditava que, como a conservava por dois anos inteiros, realmente deveria levar um mês. Ele poderia examiná-la ao espelho, a cada três ou quatro dias. Assim, conseguiria 
descobrir quando tivesse sarado. Talvez ele quisesse escrever durante mais um fim de semana depois que ela tivesse sarado.

Ele deveria começar às seis da manhã e tomar o desjejum mais tarde. Disse à mãe, em particular, que levasse um bom tempo para lhe servir o café da manhã, de modo que ele pudesse descansar um pouco. A cada duas horas, poderia fazer um intervalo para um lanche - constituído essencialmente por um suco de frutas - ou para tomar água.

Então poderia inspecionar o trabalho do pai nas tarefas domésticas e voltar a escrever. Expliquei que a mão ficaria dolorida no final da primeira semana. E o que deveria fazer? Salientei que nos intervalos deveria abrir e fechar a mão rapidamente, para relaxar os músculos. Isto aumentaria a fadiga, mas manteria os músculos flexíveis. Disse que acreditava que, depois do jantar, ele realmente deveria ficar livre do trabalho do dia. Na verdade, eu não me importaria se ele parasse às quatro da tarde. Ao tornar o horário de encerramento um tema indiferente para mim, retirei o aspecto punitivo.

O menino escreveu o dia inteiro, no sábado e no domingo; todos os fins de semana. Recebi uma imensa pilha de papeis contendo a frase - tudo escrito com orgulho e contentamento. O pai não precisava instigá-lo, e tanto ele quanto a mãe estavam surpresos com o orgulho que o menino sentia com sua caligrafia. A sentença, mil vezes escrita, foi lindamente executada. Deixei claro aos pais que a inspeção da caligrafia era de minha competência. Se ele quisesse mostrar aos pais, tudo bem, mas eu era o inspetor. Eu examinava cada página. Disse ao menino que deveria dar uma olhada rápida, apressada, em cada página, e perguntei se havia alguma à qual eu deveria prestar mais atenção. Deste modo, ele me absolveu do exame rápido.

Quanto mais escrevia, mais justificativas tinha para inspecionar o trabalho do pai. Quanto mais escrevia, mais caprichado ficava o que escrevia. Todos os dados estavam voltados para o progresso. Com este método, fiz com ele (sic!) deixasse de cutucar compulsivamente a ferida e o obriguei a escrever compulsivamente, com capricho, algo do que poderia ter um enorme orgulho.

O pai comentou: "Eu sabia o que tinha que fazer. Fiz um belo trabalho naquele gramado". O menino sentia o maior prazer ao descobrir uma folha sobre a grama. $\bigcirc$ 
pai cuidou de todo o gramado e do jardim, consertou a cerca, fez todas as tarefas, e o menino escreveu sua frase.

Num mês a úlcera estava curada. Um ano mais tarde, não havia voltado. Daquela úlcera crônica, indolente, horrível, não havia nem mesmo uma cicatriz.

Coloquei a pilha de papel escrita pelo menino no meu arquivo e perguntei-lhe por quanto tempo deveria guardá-la. Enchia completamente um arquivo. Ele respondeu que acreditava que eu gostaria de guardá-la durante alguns meses. Perguntei-lhe 0 que deveria fazer depois. Ele respondeu: "Ah, a esta altura será somente um monte de papel usado". 